\title{
‡USGS

In cooperation with the Vermont Army National Guard

Hydrogeologic Framework and Water Quality of the Vermont Army National Guard Ethan Allen Firing Range, Northern Vermont, October 2002 through December 2003

Scientific Investigations Report 2005-5159 


\section{Hydrogeologic Framework and Water Quality of the Vermont Army National Guard Ethan Allen Firing Range, Northern Vermont, October 2002 through December 2003}

By Stewart F. Clark, Jr., Ann Chalmers, Thomas J. Mack, and Jon C. Denner

In cooperation with the Vermont Army National Guard

Scientific Investigations Report 2005-5159 


\section{U.S. Department of the Interior \\ Gale A. Norton, Secretary \\ U.S. Geological Survey \\ P. Patrick Leahy, Acting Director}

U.S. Geological Survey, Reston, Virginia: 2005

For sale by U.S. Geological Survey, Information Services
Box 25286, Denver Federal Center
Denver, CO 80225
For more information about the USGS and its products:
Telephone: 1-888-ASK-USGS
World Wide Web: http://www.usgs.gov/

Any use of trade, product, or firm names in this publication is for descriptive purposes only and does not imply endorsement by the U.S. Government.

Although this report is in the public domain, permission must be secured from the individual copyright owners to reproduce any copyrighted materials contained within this report.

Suggested citation:

Clark, S.F., Jr., Chalmers, Ann, Mack, T.J., and Denner, J.C., 2005, Hydrogeologic framework and water quality of the Vermont Army National Guard Ethan Allen Firing Range, northern Vermont, October 2002 through December 2003: U.S. Geological Survey Scientific Investigations Report 2005-5159, 48 p. 


\section{Acknowledgments}

The authors would like to thank the personnel of the Vermont Army National Guard for their assistance with this study. Special thanks go to Lieutenant Colonel Raymond P. Bouchard and Lieutenant Colonel George Bergeron for guidance and input on study design, Michael O'Hara and Sergeant Neal Sargent for logistical support in field operations, and Edward Rounds for technical assistance. The authors also wish to thank the following U.S. Geological Survey personnel for their involvement: Martin Risch, of the Indiana Water Science Center, for general project guidance; and from the New Hampshire-Vermont Water Science Center, James Degnan and Craig Johnston for GIS assistance, Jeffrey Deacon for surface-water and fish-tissue sampling, Anita Cotton for graphic assistance, and Glenn Berwick and Jeffery Grey for drilling. 



\section{Contents}

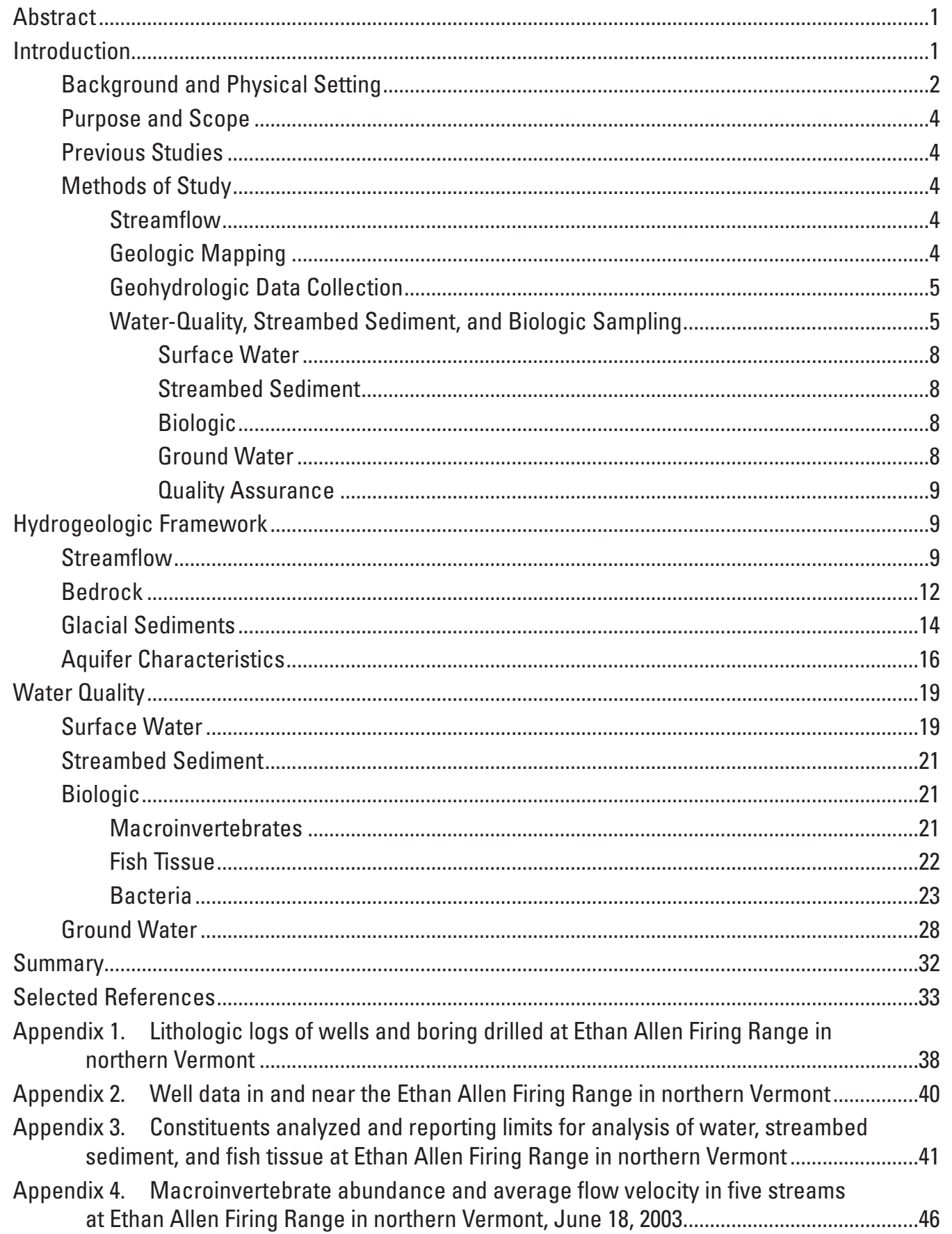




\section{Figures}

1. Map showing location of the Ethan Allen Firing Range in northern Vermont.

2. Map showing hydrologic observation points in the Ethan Allen Firing Range in northern Vermont.

3. Graphs showing (A) Daily mean streamflow at U.S. Geological Survey streamflowgaging station on the Lee River at the Ethan Allen Firing Range in northern Vermont, December 17, 2002, through December 22, 2003 and (B) monthly total precipitation at Mount Mansfield, Vermont

4-6. Graphs showing-

4. Monthly total runoff at the Dog River, Ranch Brook, and Lee River streamflowgaging stations in northern Vermont, January 1, 2003, through November 30, 2003 ......10

5. Normalized runoff hydrographs of the Dog River, Ranch Brook, and Lee River streamflow-gaging stations in northern Vermont, December 16, 2002, through December 22, 2003

6. Stream stage at the West Branch Little River, Ranch Brook, and Lee River in northern Vermont, June 10-30, 2003.

7-8. Maps showing-

7. Bedrock geology at the Ethan Allen Firing Range in northern Vermont...........................12

8. Surficial materials at the Ethan Allen Firing Range in northern Vermont

9. Diagram showing hydrogeologic section of the Lee River Valley, Ethan Allen Firing Range in northern Vermont ..................................................................................17

10. Map showing generalized altitude of the water table in the Lee River and Mill Brook watersheds at the Ethan Allen Firing Range in northern Vermont .................18

11. Diagram showing a generalized hydrogeologic section

12. Map showing generalized saturated thickness of stratified-drift deposits in the Ethan Allen Firing Range in northern Vermont

13. Graph showing comparison of macroinvertebrate taxa and Ephemeroptera, Plecoptera, and Trichoptera (EPT) richness index collected over a 15-year span from the Lee River at the outlet of the Ethan Allen Firing Range (SS-5) in northern Vermont. 


\section{Tables}

1. Well-depth and screened-interval data for the wells in the study area, Ethan Allen Firing Range, northern Vermont..

2. Summary of physical properties and water-quality characteristics of surface water at the Ethan Allen Firing Range in northern Vermont.

3. Estimated horizontal hydraulic conductivity of aquifer materials in the region in northern Vermont from Mack (1995).

4a. Concentrations of dissolved major ions, trace elements, and nutrients in surface water during moderate and low-flow conditions at the Ethan Allen Firing Range in northern Vermont.

4b. Concentrations of nutrients in surface water during moderate and low-flow conditions at the Ethan Allen Firing Range in northern Vermont.

5. Comparison of surface-water chemistry at three stream sites at the Ethan Allen Firing Range in northern Vermont, 1992, 1999, and 2003.

6. Concentrations of major ions and trace elements in streambed sediment at the Ethan Allen Firing Range in northern Vermont.

7. Comparison of trace-element concentrations in streambed sediment collected at the Ethan Allen Firing Range in northern Vermont, 1992, 1999, and 2003.

8. Concentrations of major ions and trace elements in fish tissue at the Ethan Allen Firing Range in northern Vermont.

9. Comparison of trace-element concentrations in fish tissue from the Lee River at the Ethan Allen Firing Range in northern Vermont.

10. Summary of physical properties and water-quality characteristics of ground water at the Ethan Allen Firing Range in northern Vermont.

11. Concentrations of dissolved major ions and trace elements in ground water at the Ethan Allen Firing Range in northern Vermont

12. Nutrient concentrations in ground water at the Ethan Allen Firing Range in northern Vermont. 


\section{Conversion Factors and Datum}

\begin{tabular}{lcl}
\hline \multicolumn{1}{c}{ Multiply } & \multicolumn{1}{c}{ By } & \multicolumn{1}{c}{ To obtain } \\
\hline millimeter $(\mathrm{mm})$ & 0.03937 & inch (in.) \\
centimeter $(\mathrm{cm})$ & 0.3937 & inch (in.) \\
meter $(\mathrm{m})$ & 3.281 & foot $(\mathrm{ft})$ \\
kilometer $(\mathrm{km})$ & 0.6214 & mile $(\mathrm{mi})$ \\
\hline & \multicolumn{1}{c}{ Area } & \\
\hline square meter $\left(\mathrm{m}^{2}\right)$ & 0.0002471 & acre \\
square kilometer $\left(\mathrm{km}^{2}\right)$ & 0.3861 & square mile $\left(\mathrm{mi}^{2}\right)$ \\
\hline Volume & \\
\hline liter $(\mathrm{L})$ & 0.2642 & gallon $(\mathrm{gal})$ \\
cubic meter $\left(\mathrm{m}^{3}\right)$ & 264.2 & gallon $(\mathrm{gal})$ \\
\hline & Flow rate & \\
\hline liter per minute $\left(\mathrm{L} / \mathrm{min}^{2}\right)$ & 0.2642 & gallons per minute $(\mathrm{gal} / \mathrm{min})$ \\
meter per day $(\mathrm{m} / \mathrm{d})$ & 3.281 & foot per day $(\mathrm{ft} / \mathrm{d})$ \\
cubic meter per second $\left(\mathrm{m}^{3} / \mathrm{s}\right)$ & 35.31 & cubic foot per second $(\mathrm{ft} 3 / \mathrm{s})$ \\
\hline
\end{tabular}

Temperature in degrees Celsius $\left({ }^{\circ} \mathrm{C}\right)$ may be converted to degrees Fahrenheit $\left({ }^{\circ} \mathrm{F}\right)$ as follows:

$$
{ }^{\circ} \mathrm{F}=\left(1.8 \times{ }^{\circ} \mathrm{C}\right)+32
$$

Vertical coordinate information is referenced to the "North American Vertical Datum of 1988 (NAVD 88)"

Horizontal coordinate information is referenced to the "North American Datum of 1983 (NAD 83) unless otherwise noted.

Altitude, as used in this report, refers to distance above the vertical datum.

Abbreviations used in the report: centimeter per year ( $\mathrm{cm} / \mathrm{yr})$, inch per year (in/yr)

Water quality units used in this report: Specific conductance are measured in microsiemens per centimeter at 25 degrees Celsius; turbidity in nephelometric turbidity units (NTU); concentrations in milligrams per liter ( $\mathrm{mg} / \mathrm{L})$; milligram per kilogram $(\mathrm{mg} / \mathrm{kg})$ 


\title{
Hydrogeologic Framework and Water Quality of the Vermont Army National Guard Ethan Allen Firing Range, Northern Vermont, October 2002 through December 2003
}

\author{
By Stewart F. Clark, Jr., Ann Chalmers, Thomas J. Mack, and Jon C. Denner
}

\section{Abstract}

The Ethan Allen Firing Range of the Vermont Army National Guard is a weapons-testing and training facility in a mountainous region of Vermont that has been in operation for about 80 years. The hydrologic framework and water quality of the facility were assessed between October 2002 and December 2003. As part of the study, streamflow was continuously measured in the Lee River and 24 observation wells were installed at 19 locations in the stratified drift and bedrock aquifers to examine the hydrogeology. Chemical analyses of surface water, ground water, streambed sediment, and fish tissue were collected to assess major ions, trace elements, nutrients, and volatile and semivolatile compounds. Sampling included 5 surface-water sites sampled during moderate and low-flow conditions; streambed-sediment samples collected at the 5 surface-water sites; fish-tissue samples collected at 3 of the 5 surface-water sites; macroinvertebrates collected at 4 of the 5 surface-water sites; and ground-water samples collected from 10 observation wells, and Escherichia coli samples collected at all surface- and ground-water sites.

The hydrogeologic framework at the Ethan Allen Firing Range is dominated by the upland mountain and valley setting of the site. Bedrock wells yield low to moderate amounts of water ( 0 to 23 liters per minute). In the narrow river valleys, layered stratified-drift deposits of sand and gravel of up to 18 meters thick fill the Lee River and Mill Brook Valleys. In these deposits, the water table is generally within 3 meters below the land surface and overall ground-water flow is from east to west.

Streamflow in the Lee River averaged 0.72 cubic meters per second (25.4 cubic feet per second) between December 2002 and December 2003. Streams are highly responsive to precipitation events in this mountainous environment and a comparison with other nearby watersheds shows that Lee River maintains relatively high streamflow during dry periods.

Concentrations of trace elements and nutrients in surfacewater samples are well below freshwater-quality guidelines for the protection of aquatic life. Brook-trout samples collected in 1992 and 2003 show trace-metal concentrations have decreased over the past 11 years. Escherichia coli concentrations in water samples are well below levels that restrict swimming at all five stream sites at moderate and low-flow conditions and in all observation wells. Comparisons among surface-water, streambed-sediment, and biological samples collected in 2003 to earlier studies at the Ethan Allen Firing Range indicate water-quality conditions are similar or have improved over the past 15 years.

Ground water in the stratified-drift aquifers at the facility is well buffered with relatively high alkalinities and $\mathrm{pH}$ greater than 6 . Concentrations of arsenic, cadmium, chromium, lead, nickel, uranium, and zinc were below detection levels in ground-water samples. Barium, cobalt, copper, iron, manganese, molybdenum, and strontium were the only trace elements detected in ground-water samples. Cobalt and iron were detected at low levels in two wells near Mill Brook, and copper was detected at the detection limit in one of these wells. These same two wells had concentrations of barium and manganese 2 to 10 times greater than other ground-water samples. Concentrations of nutrients are at or below detection levels in most ground-water samples. Volatile organic compounds and semivolatile organic compounds were not detected in any water samples from the Ethan Allen Firing Range.

\section{Introduction}

The Vermont Army National Guard (VTANG) Ethan Allen Firing Range (EAFR) is composed of $45.4 \mathrm{~km}^{2}$ $(11,220$ acres) of mountainous land and is about $19 \mathrm{~km}$ east of Burlington, in northern Vermont (fig. 1). Originally, the area was used for farming and pasture. Established by the War department in 1926 for use as an artillery range, the area has been used during the 1930s for Reserve Officer Training corps (ROTC) and two Civilian Conservation Corp (CCC) camps. In 1941, the EAFR was expanded and used as a bombing range by the Army Air Corps. From 1952 to present (2003), developmental and proof testing of newly manufactured weapons systems on $3.1 \mathrm{~km}^{2}$ within EAFR (U.S. Army, 1980) has been done by the Armament Systems Department of General 


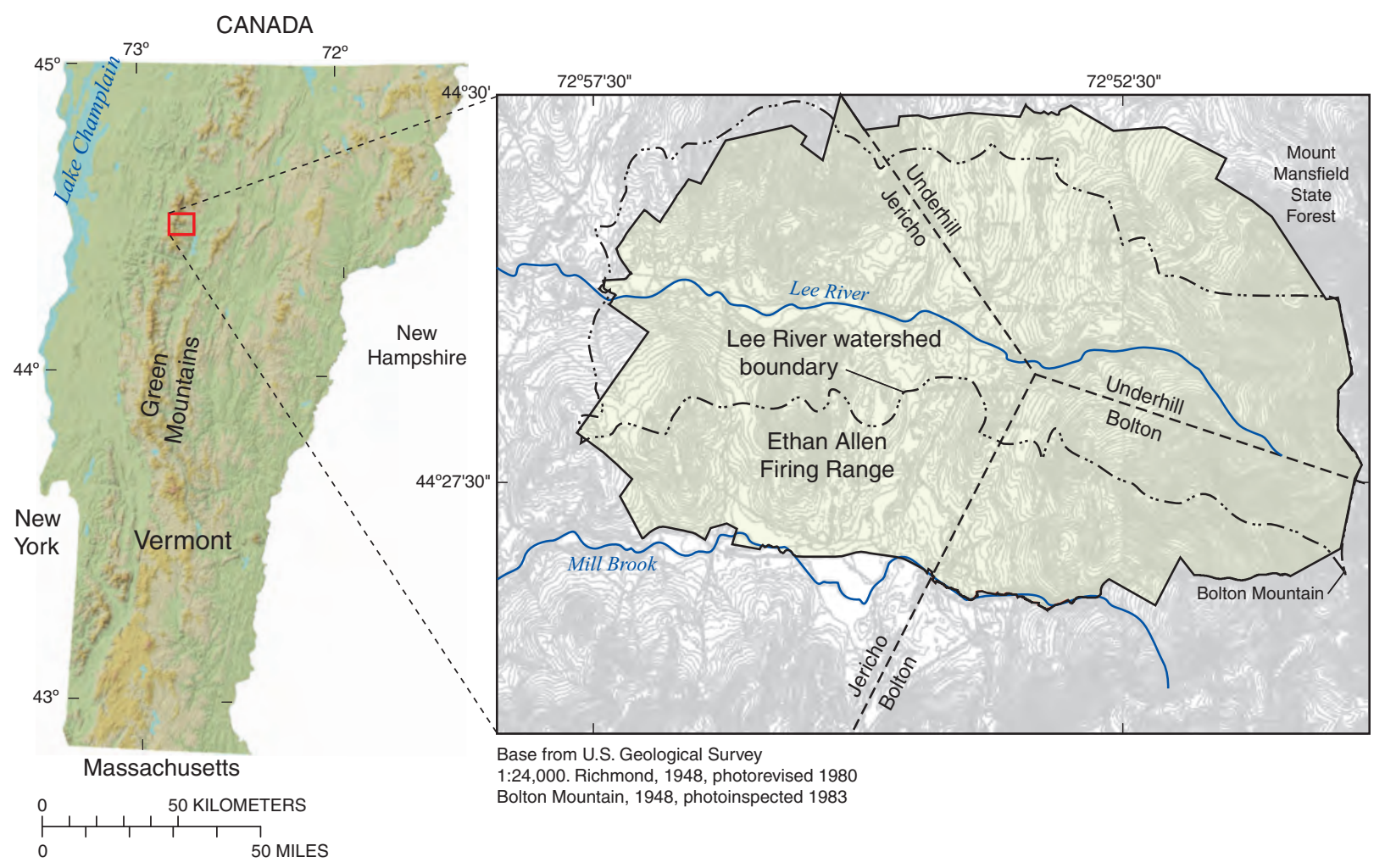

Figure 1. Location of the Ethan Allen Firing Range in northern Vermont.

Electric. The EAFR includes 18 active gunnery ranges also used by National Guard units for armor, artillery, combat engineer, and helicopter training.

The U.S. Geological Survey (USGS), in cooperation with the VTANG, did an assessment of the physical hydrogeologic framework of the site and the chemical and biologic quality of the ground water and surface water from October 2002 through December 2003. A thorough understanding of the hydrogeologic framework and water quality of EAFR is needed to quantify current (2003) water resources and provide a baseline for future activities. This study is the first base-wide geologic and hydrologic assessment of the site.

\section{Background and Physical Setting}

The EAFR is in the Green Mountains of Vermont, in the New England Physiographic Province. Altitudes range from about $213 \mathrm{~m}$ (699 ft) along the Lee River, to 1,122 m (3,681 ft) above NAVD 88 at Bolton Mountain on the eastern boundary of the range. Mount Mansfield, the highest point in Vermont, is about $11 \mathrm{~km}(6.8 \mathrm{mi})$ northeast of the site and lies on the central ridge of the north-south trending Green Mountains. The facility is rural and supports a wide variety of wildlife. Most of the EAFR is contained within a watershed drained by the Lee River in the center of EAFR (fig. 1) and is bounded by the surrounding peaks and hillsides. Mill Brook drains south- ern areas of the EAFR, and makes up much of the southern boundary, whereas a small area (Steinhour Brook) drains to the north to Browns River (outside the study area). The physiography is characterized by narrow east-west trending valleys that bisect the regional north-south trending mountain range. Precipitation averages about $86.4 \mathrm{~cm} / \mathrm{yr}$ (36 in/yr).

The EAFR facility is sparsely populated (fig. 2), consisting of a few offices, barracks, and equipment maintenance buildings in the Lee River Valley. Onsite barracks occasionally are used to house a few hundred individuals during training exercises. Weapons-training activities are held throughout the year and historically have occurred at more than 10 firing ranges in the EAFR (U.S. Army, 1980, table 4). Weapons training involves the firing of various caliber weapons at specific targets in the ranges. The use of explosive ammunition is limited to an area termed the Impact Area (fig. 2). Historically, the EAFR was used by the Vermont Militia to fire large-caliber artillery into small areas in, and adjacent to, an area called the Impact Area (the old Impact Area). This area may contain shrapnel and duds (U.S. Army, 1980, p. 26). Current (2003) policy requires an accounting of all rounds fired and tracking and exploding duds in place. A government-owned, contractor-operated (GOCO) facility in the EAFR conducts weapons test-firing operations in the Lee River Valley. Between 1969 and 1982, depleted uranium ammunition was tested at the GOCO facility. Soils were removed after the munitions testing ceased and residual radiation above background levels was not 


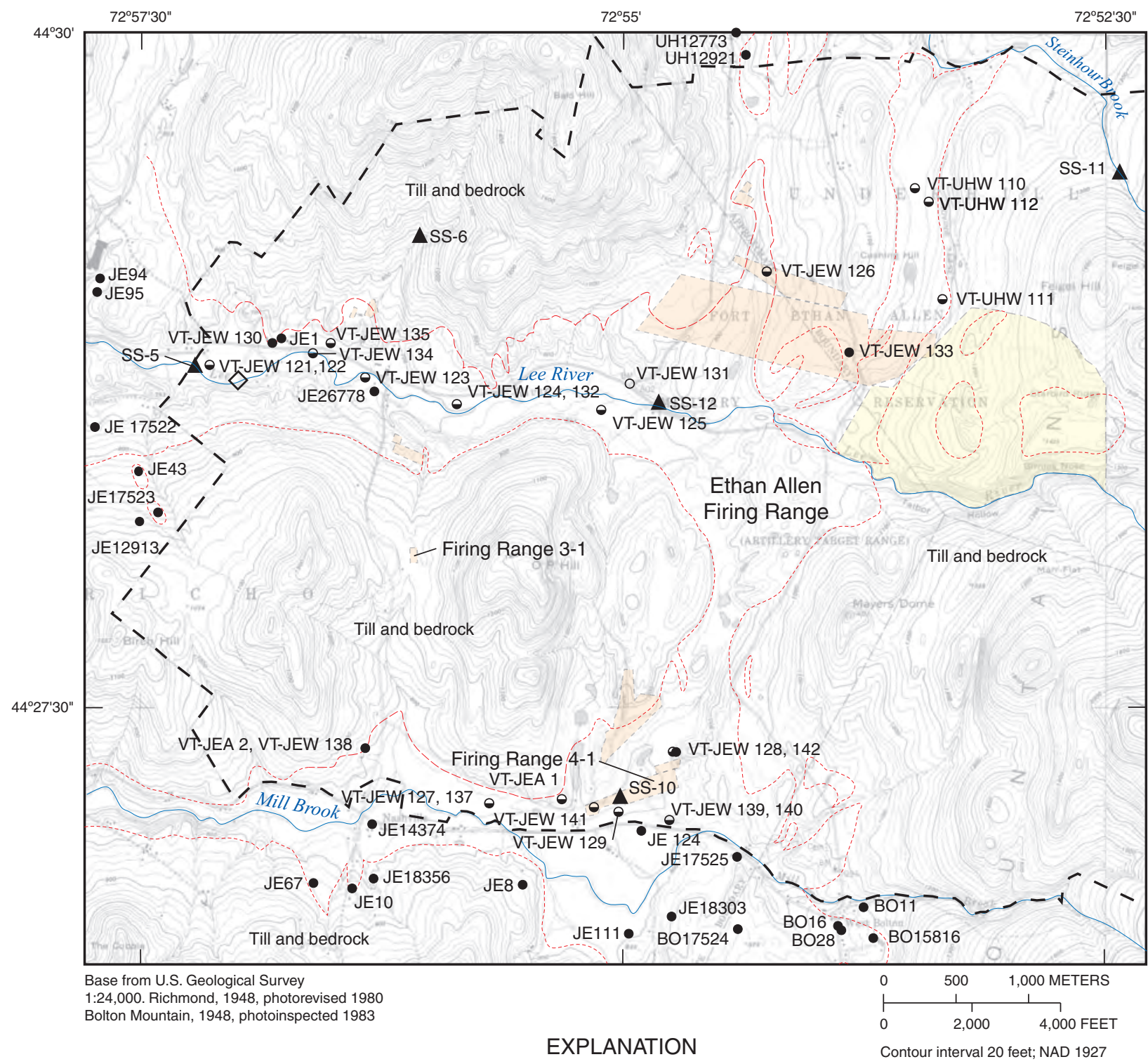

IMPACT AREA

FIRING RANGE

- - . ETHAN ALLEN FIRING RANGE BOUNDARY

STRATIFIED-DRIFT CONTACT

---- Approximate within 0 to 60 meters of true contact Inferred within 0 to 120 meters of true contact

$\diamond \quad$ STREAMFLOW-GAGING STATION

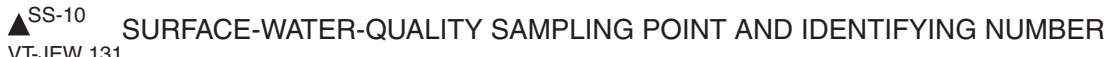

VT-JEW 131 WELL IN OVERBURDEN AND IDENTIFYING NUMBER ${ }^{1}$

VT-JEW 141 WELL OR BORING REACHED REFUSAL OR BEDROCK AND IDENTIFYING NUMBER

-JE67 WELL OR BORING PENETRATED BEDROCK AND IDENTIFYING NUMBER

1 U.S. Geological Survey identifying numbers have a VT-prefix (table 1); all others are from the Vermont Agency of Natural Resources database (Appendix 2)

Figure 2. Hydrologic observation points in the Ethan Allen Firing Range in northern Vermont. (Location of site shown in figure 1.) 
detected at the affected sites (Bonds and others, 1987). Waste materials generated from the testing activities were contained and shipped off-site to licensed disposal facilities.

Since 1999, the primary drinking-water source for the EAFR has been the Champlain Water District system. Previously, EAFR facilities were served by three onsite bedrock wells. Two, approximately 91-m-deep bedrock wells at the Mountain School Complex formerly supplied water to that facility and a 43-m-deep bedrock well formerly provided water to the Cantonment facility. The well formerly used for the Cantonment facility is now occasionally used to fill portable drinking-water-supply tanks. The GOCO facility is still supplied by onsite water from a bedrock well. Firing Range 3-1 also is supplied water onsite by an infrequently used 69-m-deep bedrock well. The West Bolton Public Water Source Protection area includes land areas in the EAFR; however, the water system is upgradient of the EAFR watershed and not likely to be affected by activities at the firing range.

\section{Purpose and Scope}

The purpose of this report is to present (1) the hydrogeologic framework including a description of surficial and bedrock geology, areal extent of stratified-drift aquifers, watertable altitudes, general directions of ground-water flow, and saturated thickness; (2) the surface-water discharge of the Lee River watershed in order to understand the watershed hydrology and stream-aquifer interactions at the EAFR; and (3) the general quality of surface water, streambed sediment, fish tissue, biota, and ground water. The area of study is delineated by the EAFR site boundary. The study was performed at the watershed scale.

\section{Previous Studies}

Bedrock geology of the region including the EAFR has been described and mapped by Christman and Secor (1961), Mallard (2000), and Thompson and Thompson (1997). Surficial geology and hydrology have been studied by Stewart and MacClintock (1969), Stewart (1973), Ladue (1982), and Clapp and Bierman (1994).

Surface-water and streambed-sediment samples were collected and analyzed in 1992 at 10 sites on the Lee River and Mill Brook (Bouwkamp, 1992) and again in 1999 at the same locations (Goetz, 1999). Ten locations sampled in 1999 did not indicate an adverse effect on water quality or streambed sediment from munitions training (Goetz, 1999). Fish-tissue samples were collected and analyzed at two sites on the Lee River in 1992; the 1999 survey did not include chemical analysis of fish tissue. Macroinvertebrate samples were collected from five sites on the Lee River in 1992 and six sites in 1999. Three of the six sites sampled in 1999 corresponded to sites sampled in 1992. Results from 1999 were inconclusive, taxa richness was higher (an indication of improving water quality) in 1992 than in 1999, but macroinvertebrate abundance was lower than in 1999. Although ground-water sampling in the stratified-drift aquifer was done to test for potential contamination at two locations (a former waste-disposal site and a logistical-operations building) at the EAFR (Butoryak, 1995 and 1996), previous studies have not included a comprehensive investigation of ground-water resources and background water quality.

\section{Methods of Study}

The following section describes the methods used to accomplish the objectives of the study. These methods include streamflow gaging; geohydrologic data collection including lineament analysis, observation-well drilling, and mapping; and water-quality, streambed sediment, and biologic sampling. Databases and geographic information system (GIS) coverages used to complete analysis of the geohydrologic framework are referenced or described.

\section{Streamflow}

Streamflow was gaged at the Lee River between December 16, 2002, and December 22, 2003, to assess the magnitude and range of streamflow in the Lee River watershed. The streamflow-gaging station (fig. 2) was located near where the river leaves the EAFR. Streamflow measured at the Lee River station was indexed to nearby stations to provide a context for understanding flow in the Lee River during water year 2003, in relation to long-term regional trends. Specific study methods included

1. Installation of a continuously recording streamflowgaging station at the Lee River to allow streamflow in the watershed to be indexed to nearby long-term USGS network stations. Streamflow data were collected using standard USGS techniques (Rantz and others, 1982; Buchannan and Somers, 1969). The station at Lee River was equipped with a datalogger that recorded stage data at 10-minute intervals. A stage-discharge relation was developed from numerous current-meter discharge measurements.

2. Additional streamflow measurements were made at two sites on Lee River (above and below the station), and on tributaries to Lee River and at Steinhour Brook (fig. 2, SS-11), to assess flow conditions during the sampling period at macroinvertebratesampling sites.

\section{Geologic Mapping}

Bedrock geologic maps at a scale of 1:24,000, which include areas of the EAFR, were made by Mallard (2000) and Thompson and Thompson (1997). A 1:100,000-scale compilation by the Vermont Geological Survey (Stanley and others, 2002) forms the basis for the bedrock geologic map. Bedrock outcrops were located and examined during the course of this 
study; however, no revision of Mallard's (2000) or Thompson and Thompson's (1997) work was warranted.

A map of generalized surficial geologic materials was prepared based on observations of materials exposed in eroding unconsolidated cliffs, gravel pits, road cuts, stream banks, pits dug in unconsolidated materials, well borings, split-spoon samples from observation wells, and the distribution of boulders on the land surface. A 1:62,500-scale surficial-geologic map including the EAFR, accompanies Christman and Secor's (1961) report on the geology of the Camels Hump Quadrangle. Christman and Secor's (1961) surficial-materials map and maps by Stewart (1973) and Ladue (1982) and interpretations by Ladue (1982) are consistent with those of this study.

\section{Geohydrologic Data Collection}

Observation wells were located to assess the geohydrologic framework and local and regional ground-water-flow systems. Wells were installed along the central axis of the Lee River and Mill Brook Valleys to determine the thickness of valley-fill deposits and the general gradient of the water table. Wells were located at the valley perimeter along the main stem of each river and in headwater stream reaches to determine general ground-water-flow directions and provide points for assessment of ground-water quality. Rock core retrieved from observation wells drilled in bedrock provided a measure of the extent of fracturing within the bedrock aquifer (Deere and Deere, 1988). Additional existing domestic bedrock wells, beyond the boundary of the EAFR, were identified to provide data relevant to aquifers underlying the study area.

Characteristics of the bedrock aquifer are described by well depths and yields. Domestic-well data were obtained from the Vermont Agency of Natural Resources (Ken Yelsey, Vermont Agency of Natural Resources, written commun., 2004). Domestic wells were reviewed and assessed for use in estimating stratified-drift aquifer thicknesses.

A photolineament analysis of the study area identified potential high-transmissivity bedrock zones. Moore and others (2002) found that increased bedrock-well yields were associated with lineaments that correlated with the direction of primary bedrock fracturing in New Hampshire. Two observers independently identified linear patterns on 1:58,000-scale color-infrared aerial photographs following the methods of Clark and others (1996). Coincident photolineaments identified by two observers are provided in the GIS lineaments coverage. Comparison of photolineament position and orientation with field-measured fractures at outcrop-scale was beyond the scope of this study; therefore, the relation between photolineaments and bedrock structure at the study area is uncertain.

Observation wells were installed at 16 locations (fig. 2, table 1) in glacial sediments to improve the understanding of the thickness and nature of stratified-drift aquifers. Pairs of wells with screens set relatively shallow and deep were installed at four locations to assess ground-water quality and head difference from different depths within the aquifers. Split-spoon samples were collected at approximately 3-m intervals to determine the composition of the sediments with increasing depth. Lithologic logs of wells drilled at the EAFR are presented in appendix 1. Information from well reports from the surrounding area collected by the VTANR is provided in appendix 2. Stratified-drift wells consisted of a $5-\mathrm{cm}$ (2-in.) inside-diameter polyvinyl chloride (PVC) well and $1.5-\mathrm{m}$ long, $0.01-\mathrm{mm}$ slotted screen. Four bedrock wells were installed in selected locations to improve the understanding of the bedrock aquifer. Bedrock wells consisted of a 10-cmdiameter open borehole drilled in rock. Boreholes were cased with 11-cm outer-diameter steel casing, set into a 15 -cm-diameter hole, grouted with cement approximately $1.5 \mathrm{~m}$ into the bedrock surface. Well characteristics and construction information are provided in table 1 . The wells were used to provide ground-water-sampling points and are shown on figure 2. Numbers assigned to wells consist of a code that corresponds to the town the site is in and a sequential number. Well codes used are BO, Bolton; JE, Jericho; and UH, Underhill.

Depth to the water table in the stratified-drift (layered sands and gravel) aquifers was used to determine the altitude of the water table. Measurements of the depth to the water table were obtained from measurements made for this study, well-completion-report records maintained by the VTANR, and from approximated altitudes of the surface of ponds and streams as shown on USGS 1:24,000-scale topographic maps. The altitude of the water-table surface generally fluctuates by less than $2 \mathrm{~m}$ during the year at observation wells in northern Vermont (Keirstead and others, 2004); therefore, measurements from various times of the year are sufficient for use in creating a regional water-table map and in determining general directions of ground-water flow. The saturated thickness of the stratified-drift aquifers was determined using the data mentioned above in addition to the thickness of stratified glacial sediments as reported in drillers' well-completion reports (appendix 2).

\section{Water-Quality, Streambed Sediment, and Biologic Sampling}

Surface-water sampling sites (fig. 2, table 2) were selected to assess surface-water, streambed-sediment and biologic quality at EAFR. Sites were selected that were at, or near, 4 of the 10 previous sampling sites (Goetz, 1999) to provide continuity and correlation with the previous studies. Sites SS-5, SS-6, and SS-10 (fig. 2) were coincident with previous sample sites (Lieutenant Colonel Bouchard, Vermont Army National Guard, oral commun., 2003). Site SS-5 provides a surface-water sampling site that captures most of EAFR drainage and provides a measure of the overall quality of water leaving the base. In contrast, site SS-6 provides an analysis of a relatively undisturbed upland tributary drainage. Site SS-12 (fig. 2), about $305 \mathrm{~m}$ downstream from site SS-3 (Goetz, 1999), is downstream of all tributaries draining the Impact Area. This site provides an indicator of the effect of the Impact Area, and other active firing ranges to the north, 
Table 1. Well-depth and screened-interval data for the wells in the study area, Ethan Allen Firing Range, northern Vermont.

[Site locations are shown in figure 2. Latitude and longitude are in degrees, minuntes, seconds, ‘ ' '. All depths in meters from land-surface datum. Measurement point (MP) is top of casing. Altitude is in meters (m) above NAVD 88; L/min, liter per minute; --, not applicable or unknown]

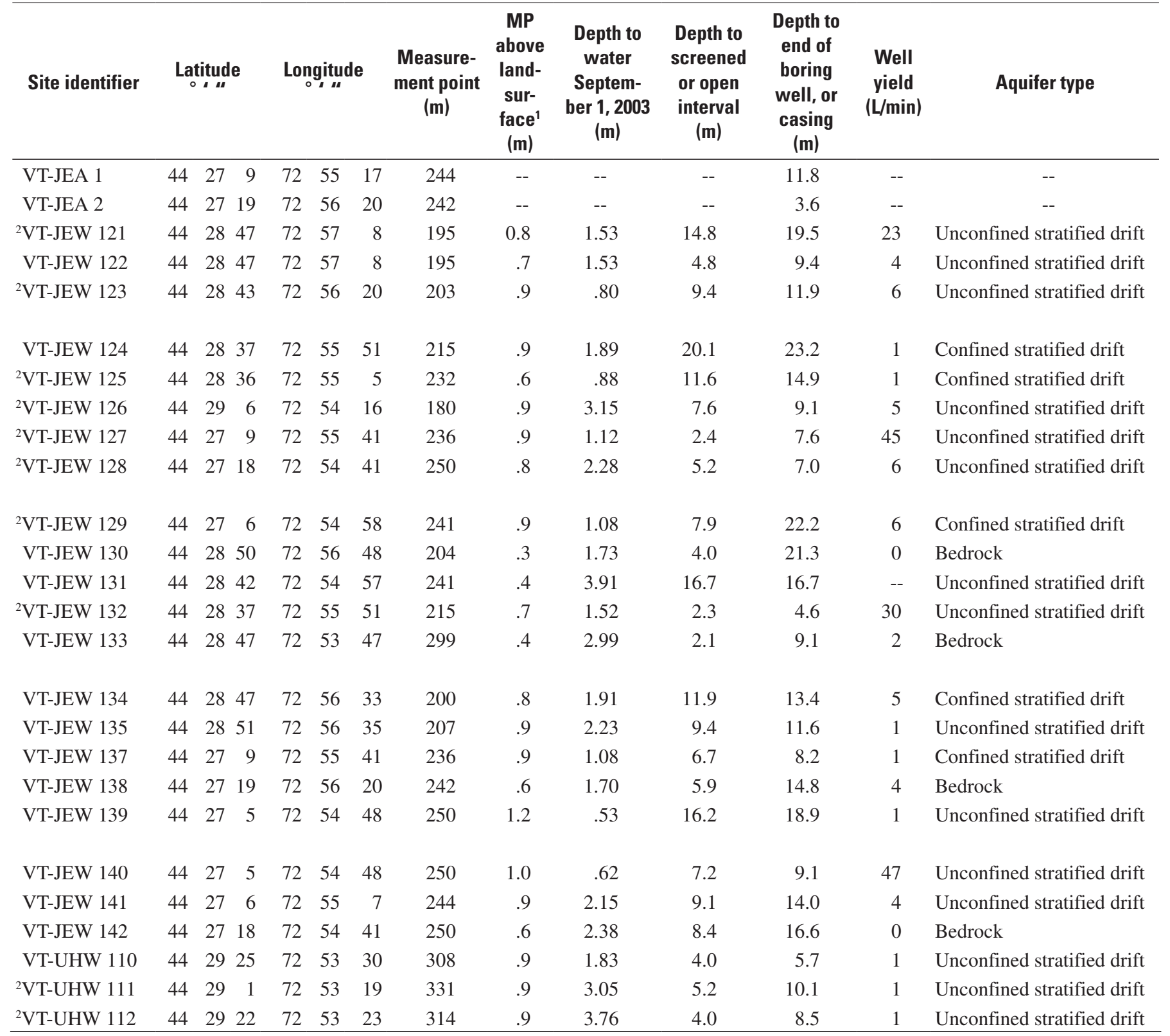

${ }^{1}$ Land-surface altitude determined from map altitude, vertical accuracy is approximately 3 meters.

${ }^{2}$ Wells sampled. 


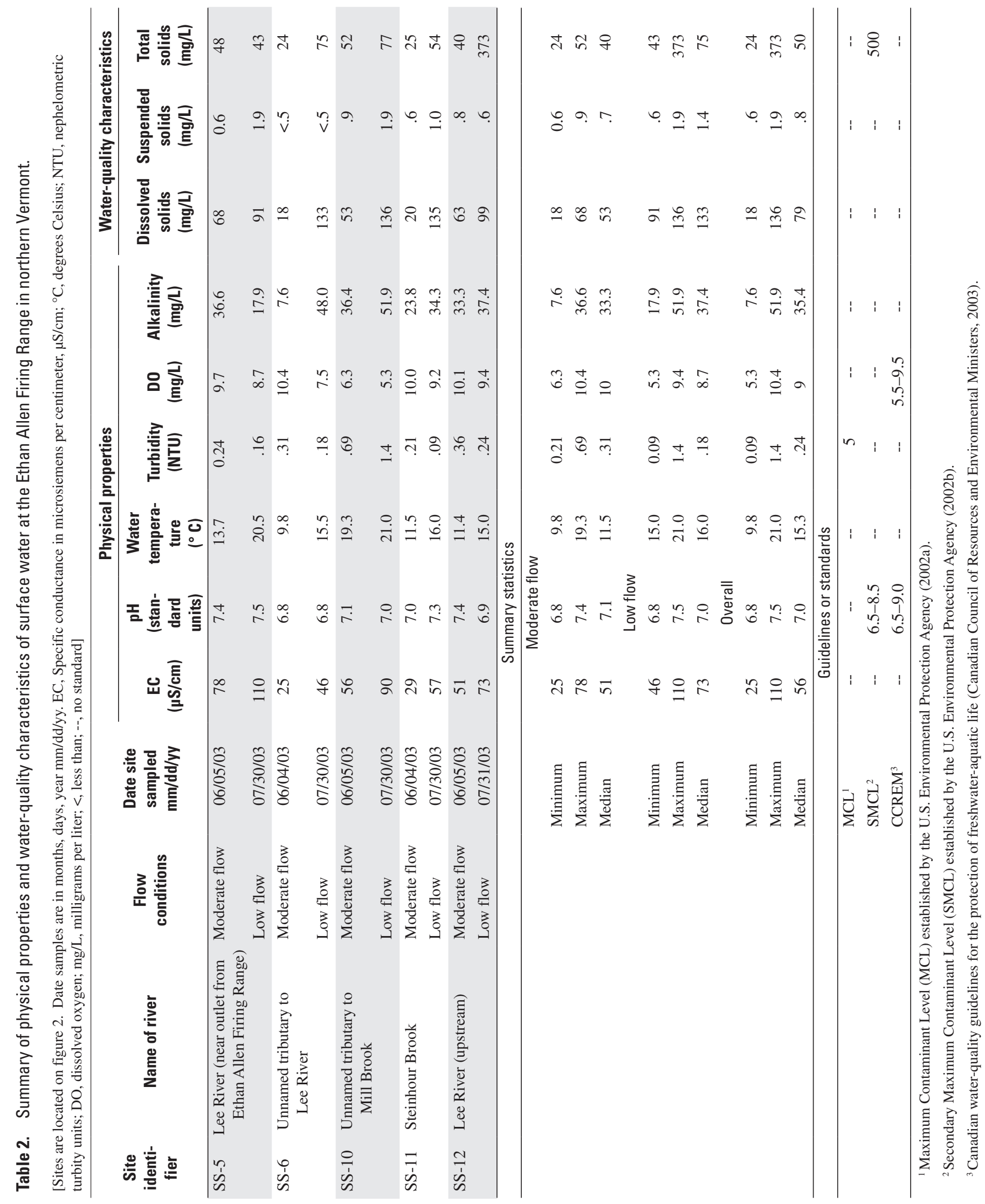


on the water quality of the Lee River. Site SS-11, on Steinhour Brook, was used to assess water quality from the one watershed that drains to the north, towards Underhill (fig. 1), from the study area. Site SS-10, a tributary to Mill Brook, was selected to provide an indicator of the effect of Guard activities along the southern side of the EAFR in the Mill Brook watershed. Because most of Mill Brook watershed is outside the EAFR area, no other sites in this watershed were assessed.

Surface- and ground-water chemistry, streambed sediment, benthic macroinvertebrates, and fish samples were collected in the Lee River watershed during June and July 2003. Water-quality and biological data collection focused on background sampling (sampling from relatively pristine areas within the EAFR) in addition to assessing the overall water quality of the study area. Field data collection included (a) surface- and ground-water samples, (b) streambed-sediment samples, (c) fish-tissue samples, and (d) an aquatic macroinvertebrate inventory. Water, streambed-sediment, and fish-tissue samples were analyzed for major ions and trace elements listed in appendix 3. Water samples were also analyzed for alkalinity, turbidity, dissolved solids, total suspended solids, Escherichia coli (E-coli) bacteria, nutrients, volatile organic compounds (VOCs) identified in U.S. Environmental Protection Agency (USEPA) schedule 8260, and semivolatile organic compounds (SVOC) in USEPA schedule 8270 (appendix 3). All analyses except $E$-coli were performed at SevernTrent Laboratory (a contract laboratory for USGS Department of Defense work) using USEPA analytical methods. E-coli counts were analyzed by Aquatec Biological Sciences in Williston, Vt., in accordance with U.S. Environmental Protection Agency (1983) protocol.

Ten observation well sites (fig. 2, table 1) were selected to provide comprehensive geographic coverage for groundwater sampling and geohydrologic characteristics within selected aquifers. Observation-well-site selection and construction methods are described in the "Geohydrologic Data Collection" section.

\section{Surface Water}

Surface-water-quality sampling was completed at five sites (fig. 2) during moderate-flow conditions $\left(0.45 \mathrm{~m}^{3} / \mathrm{s}\right.$ at Lee River streamflow-gaging station, June 4-5, 2001), and again during a low-flow (base flow) condition $\left(0.15 \mathrm{~m}^{3} / \mathrm{s}\right.$ at the Lee River station, July 30-31, 2003). Water samples and field water-quality parameters $(\mathrm{pH}$, specific conductance, water temperature, and dissolved oxygen) were collected and measured consistent with guidelines for the USGS Field Manual for the Collection of Water-Quality Data (Wilde and others, 1998). Grab samples were collected because all streams were well mixed. E-coli, VOC, and SVOC samples were collected directly into sample containers from a single vertical midstream dip sample. Samples for major ions, trace elements and nutrients were dip-collected with a Teflon bottle and composited using a Teflon churn.

\section{Streambed Sediment}

Fine-grained streambed sediment consisting primarily of very fine sand, silt, clay and organic material were collected from depositional areas at five stream sites during base-flow conditions on July 4, 2003. Composite samples were collected from the top 2-3 cm of continuously submerged streambed sediment from 10 to 15 depositional areas in a manner consistent with guidelines for the USGS National Water-Quality Assessment Program (Shelton and Capel, 1994). Samples were not sieved, however, to permit for comparison with unsieved samples collected in 1992 and 1999. Samples were analyzed for major ions and trace elements (appendix 3).

\section{Biologic}

Fish were collected at three sites by electrofishing during moderate-flow conditions (June 10-11, 2003). Brook trout (Salvelinus fontinalis) were collected at sites SS-11 and SS-12 (fig. 2). Brook and brown trout (Salmo trutta) were collected at site SS-5. Fish-tissue samples were a composite of five whole individuals. Samples were analyzed for major ions and trace elements (appendix 3). Benthic macroinvertebrates were collected at four stream sites (SS-5, SS-6, SS-11, and SS-12) in the Lee River and Steinhour Brook watersheds on June 18, 2003. A Surber sampler was used to collect a semi-qualitative sample to provide a measure of relative abundance of invertebrate taxa living in the richest habitat (riffles) at each stream site. Organisms were dislodged in a $0.09-\mathrm{m}^{2}$ area to a depth of about $10 \mathrm{~cm}$ immediately upstream of the sampler and collected in a $500 \mu \mathrm{m}$ mesh net. A series of five representative discrete collections were combined and processed at each site. Samples were preserved in 95-percent alcohol. Three-hundred organism counts were done by Aquatec Biological Sciences in Williston, Vt. Taxa were identified to the level of genus and species. The diversity and taxa richness of samples was compared against historical samples to test for changes in biodiversity and population numbers.

\section{Ground Water}

Ground-water samples were collected from 10 wells during July 21-25, 2003. The wells were developed from 2 to 4 weeks prior to sampling by pumping until a drop in temperature indicated that water stored in the casing was removed and that the aquifer was being pumped. A low-discharge submersible pump was used to purge and sample the wells. Purging involved setting the pump at the well screen and pumping greater than 3 times the casing volume until the $\mathrm{pH}$, specific conductance, dissolved oxygen, and water temperature stabilized. Field water-quality parameters ( $\mathrm{pH}$, specific conductance, water temperature, and dissolved oxygen) were collected according to USGS guidelines (Wilde and others, 1998). Samples were collected for major ions, trace elements, nutrients, E-coli, VOCs, and SVOCs (appendix 3). 


\section{Quality Assurance}

Water-quality assurance included equipment blanks, field blanks, and replicates collected following USGS guidelines (Wild and others, 1998). Equipment blanks were taken before any samples were collected. Approximately 10 percent of samples were collected for water-quality assurance (field blanks and replicates). Equipment and field blanks verified that decontamination procedures are adequate, and field and(or) laboratory procedures did not contaminate samples. Trip blanks were kept with the samples and analyzed for VOCs with every batch of samples brought to the lab. VOC trip blanks verified that shipping, handling, and storage of sample vials did not result in the contamination of the samples.

\section{Hydrogeologic Framework}

The EAFR is on the west flank of the central ridge of the Green Mountains (fig. 1) and is underlain by fine- to mediumgrained micaeous metamorphic rocks with a granofels or phyllite texture. Unsorted sediment deposited by glacial ice discontinuously covers bedrock. Streambed sediment associated with outwash from melting glacial ice formed stratified deposits in glacial lakes in the Lee River and Mill Brook Valleys. The hydrogeologic framework consisting of streamflow, bedrock geology, glacial sediments, and the hydrology of the bedrock and stratified-drift aquifers is described in the following sections.

\section{Streamflow}

The headwaters of the Lee River and Mill Brook drain the west flank of the central ridge of the Green Mountains (fig. 1). The Lee River represents the primary hydrologic feature in the EAFR site and its watershed encompasses most of the study area site. The drainage area for the Lee River watershed upstream of SS-5 (figs. 1 and 2) is about $26.5 \mathrm{~km}^{2}$. The drainage area for Mill Brook (fig. 2) upstream of its downstream EAFR boundary is about $15.5 \mathrm{~km}^{2}$. The only other drainage leaving the area is Steinhour Brook (fig. 2), a small tributary to Browns River (outside the study area) in Underhill. Steinhour Brook has a drainage area of about $3.4 \mathrm{~km}^{2}$ within the EAFR.

The period of record for the Lee River streamflow-gaging station is from December 16, 2002, to December 22, 2003. The period from December 17, 2002, to December 16, 2003 , was used for statistical reporting. A hydrograph of daily mean flow for the Lee River is shown in figure 3. Flows ranged from a daily maximum flow of $10 \mathrm{~m}^{3} / \mathrm{s}\left(360 \mathrm{ft}^{3} / \mathrm{s}\right)$ on November 20 , 2003 , to a low flow of $0.13 \mathrm{~m}^{3} / \mathrm{s}\left(4.7 \mathrm{ft}^{3} / \mathrm{s}\right)$ on July 19 and 20 , 2003, and September 15 and 19, 2003. The mean streamflow for the year of record was $0.72 \mathrm{~m}^{3} / \mathrm{s}\left(25.4 \mathrm{ft}^{3} / \mathrm{s}\right)$ and the runoff for the year was $85.8 \mathrm{~cm}$ (33.8 in). The streamflow record during the winter of 2003 (fig. 3) illustrates a period of recession from January through March. Although precipitation was low during this period (fig. 3), January and February were some of the coldest months observed in the past 25 years in the region and precipitation remained in the snowpack.

The Dog River streamflow-gaging station (station no. 04287000, Keirstead and others, 2004), at Northfield Falls, Vt. (43 km to the southeast of the study area), is used as a reference site to describe long-term hydrologic conditions in northcentral Vermont during the period of record at the EAFR. Streamflow at Dog River was 107 percent of normal, and total precipitation on Mt. Mansfield was 116 percent of normal. The above normal conditions at reference stations nearby indicate that Lee River streamflow during the study was probably about 10 percent above normal.

West Branch Little River (15 km to the east of the study area), a highly developed watershed, and Ranch Brook (15 km to the east), an undeveloped watershed, are nearby watersheds on the east slope of Mt. Mansfield, and have physiographic settings similar to the Lee River. Monthly total discharge in the Lee River (fig. 4) was compared to discharge in Ranch Brook (station no. 04288230) and the Dog River (station no. 04287000) (Keirstead and others, 2004). The Dog River, a large watershed $\left(197 \mathrm{~km}^{2}\right)$ in the region, with a low mean basin altitude, provided a long-term discharge record for comparison with closely paired Ranch Brook and Lee River. Total annual runoff (normalized) for the period of the Lee River record, at the three watersheds, was Dog River $65.5 \mathrm{~cm}$ (25.8 in), Ranch Brook $106.2 \mathrm{~cm}$ (41.8 in) and Lee River $85.8 \mathrm{~cm}$ (33.8 in). This comparison shows that the Dog River has the least runoff and runoff from Ranch Brook is greater than the runoff from Lee River. Peak snowmelt occurred in March at Lee River, the result of a more southerly exposure than at Ranch Brook, where peak snowmelt occurred in April (fig. 4).

The Lee River watershed on the western slopes of the Green Mountains has less (normalized) runoff than Ranch Brook on the eastern slope of the Green Mountains and may receive less precipitation. The western slope (upwind) of the Green Mountains is assumed to receive more precipitation than the eastern slope (downwind). However, the National Weather Service (NWS) indicates that the western slope may have received less precipitation in 2003 than the east slope, and evapotranspiration (ET) is likely higher on the western slopes (Gregory Hansen, National Weather Service, oral commun., 2004).

Analysis of flows per unit area in the three watersheds discussed previously shows that the Lee River maintains a relatively high discharge (greater than $0.01 \mathrm{~m}^{3} / \mathrm{s}$ ) during dry periods (fig. 5), notably July and September 2003. This comparison indicates that there is likely a large ground-water contribution to streamflow during periods of low rainfall. The Lee River watershed contains a large area of relatively permeable stratified-drift deposits (discussed in the "Glacial Sediments" section) that likely acts as a storage reservoir for ground water.

Analysis of a short-term hydrograph (fig. 6) shows that the Lee River is similar to other nearby mountain watersheds 
A.

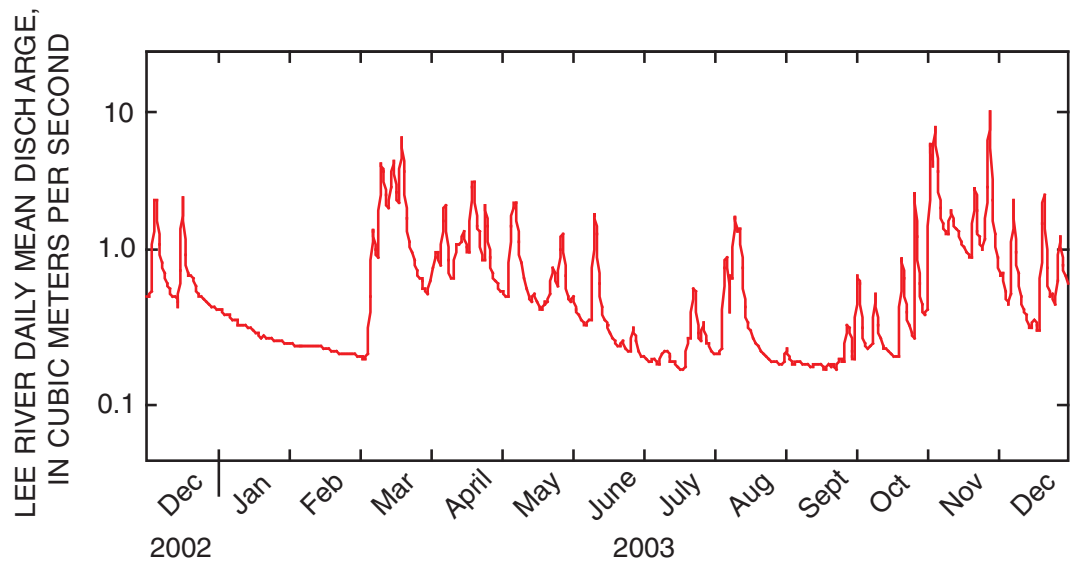

B.

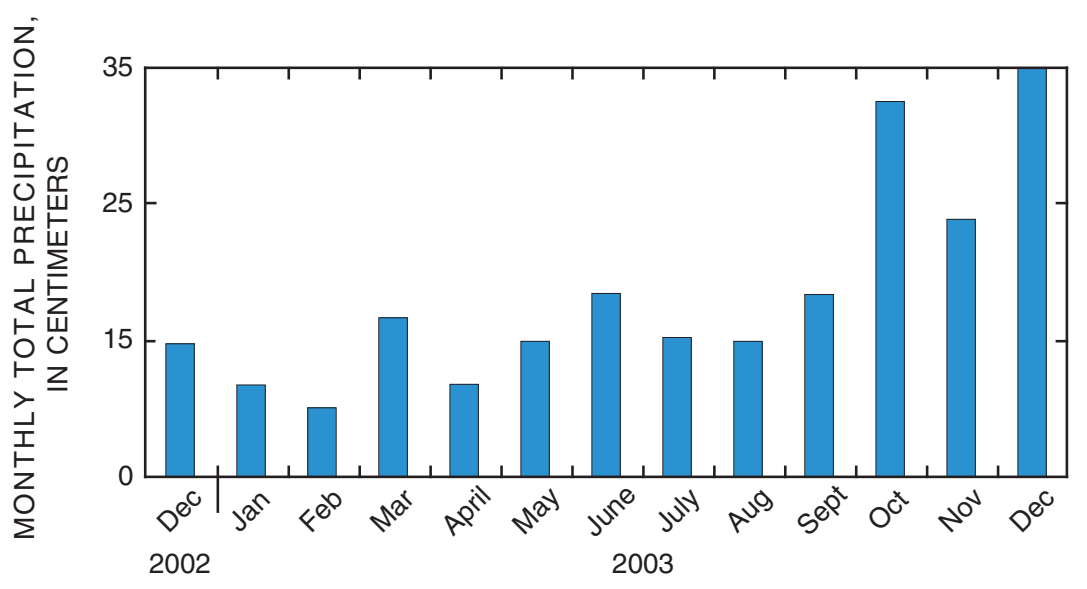

Figure 3. (A) Daily mean streamflow at U.S. Geological Survey streamflowgaging station on the Lee River at the Ethan Allen Firing Range near Jericho, Vermont, December 17, 2002, through December 22, 2003 (location shown on figure 2) and (B) monthly total precipitation at Mount Mansfield, Vermont.

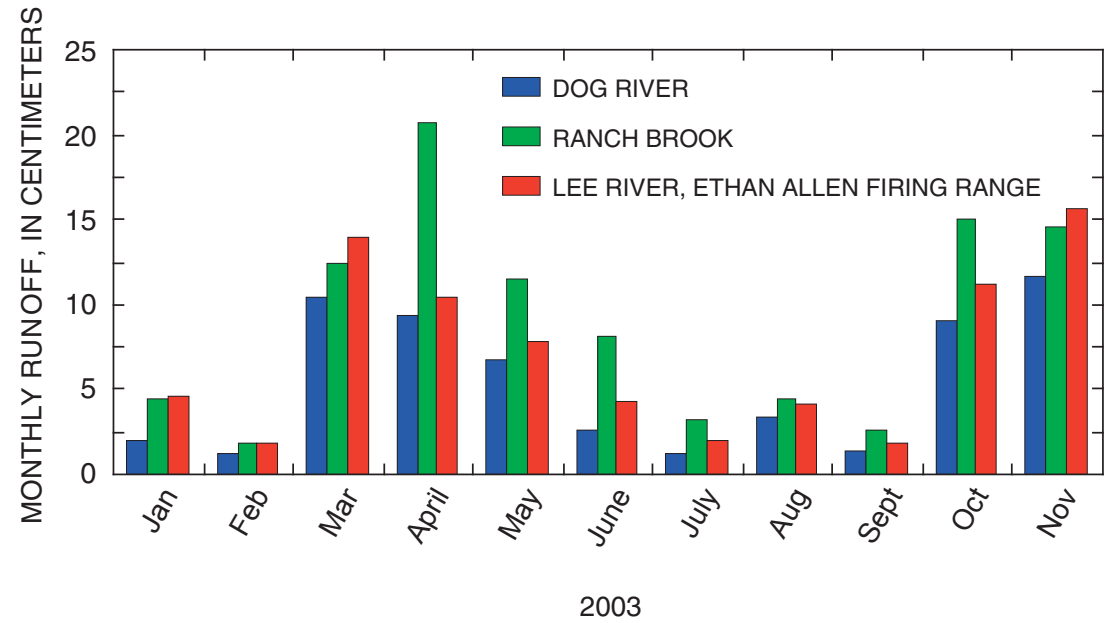

Figure 4. Monthly total runoff at the Dog River, Ranch Brook, and Lee River streamflow-gaging stations in northern Vermont, January 1, 2003, through November 30, 2003. (Location of Lee River shown in figure 1.) Dog River and Ranch Brook are outside of study area. 


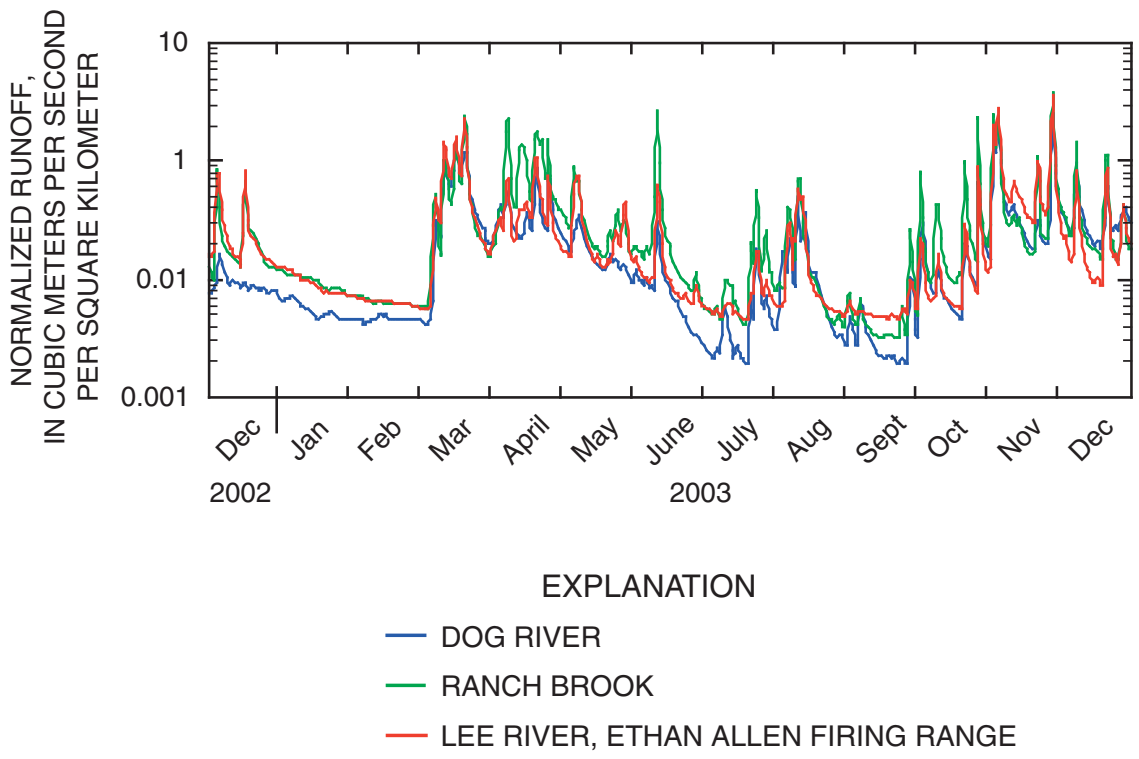

Figure 5. Normalized runoff hydrographs of the Dog River, Ranch Brook, and Lee River streamflow-gaging stations in northern Vermont, December 16, 2002, through December 22, 2003. (Location of Lee River shown in figure 1.) Dog River and Ranch Brook are outside of study area.

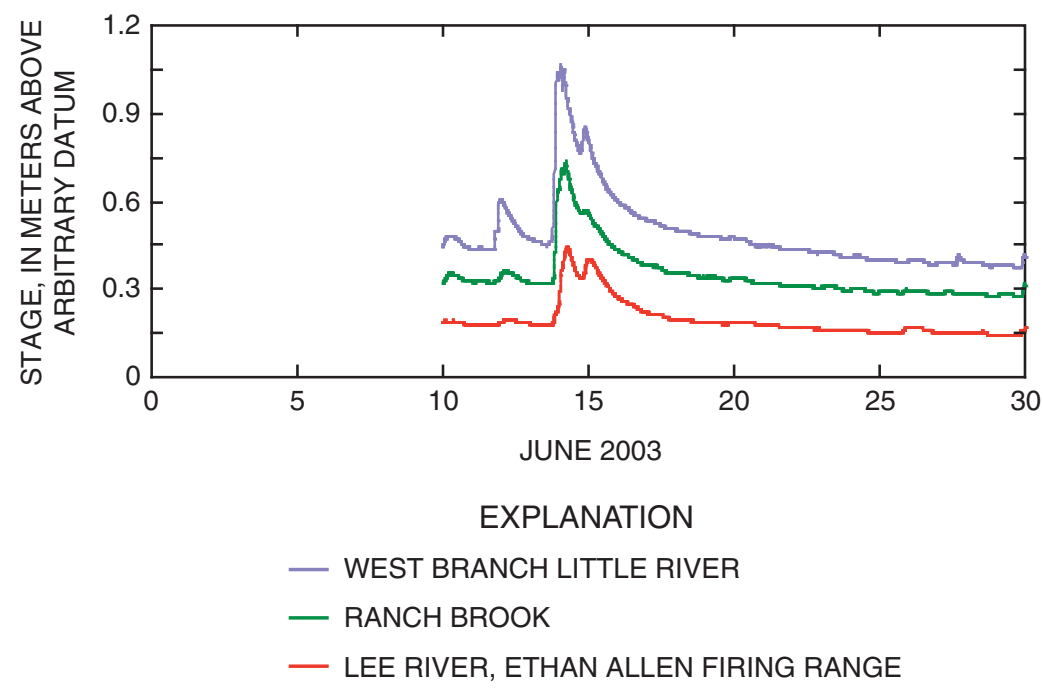

Figure 6. Hydrograph showing stream stage at the West Branch Little River, Ranch Brook, and Lee River in northern Vermont, June 10-30, 2003. (Location of Lee River shown in figure 1.) West Branch Little River and Ranch Brook are outside of study area. 
in that it is highly responsive to storm events. A typical response of mountain streams to intense rainfall is a rapid rise at the onset of precipitation followed by a fairly steep recession after the rainfall ends. The rainfall runoff response at the Lee River is slightly subdued, when compared to the West Branch Little River (fig. 6), because of the undeveloped nature of the Lee River watershed and the extensive stratified glacial sediments.

\section{Bedrock}

The texture and composition of rocks and the nature and orientation of structural elements in rocks affect the magnitude and anisotropy (orientation) of the hydraulic conductivity in the bedrock aquifer. Minerals more susceptible to weathering (such as pyrite and calcite), which may be aligned with the schistosity, can produce porosity in rocks that allows groundwater movement such as the weathered, water-producing zone identified in bedrock well VT-JEW 133. Aligned mica minerals form planar features, such as schistosity and cleavage, that control patterns of jointing in rocks and provide pathways for ground-water flow.

The EAFR, on the western flank of the Green Mountain anticlinorium, is underlain by fine- to medium-grained sandytextured micaeous metamorphic rocks consisting of low-grade granofels and phyllites. The original pre-metamorphic rocks were coarse- to fine-grained graywacke, siltstone, and shale which locally contain minor amounts of volcanic material (Christman and Secor, 1961). These rocks have been grouped into the Pinnacle, Underhill, Hazens Notch and Sweetsburg Formations in previous studies (Christman and Secor, 1961; Thompson and Thompson 1992, 1997; Mallard, 2000). Robinson and Kapo (2003) classify the general lithogeochemistry of this region as primarily noncalcareous pelitic rocks with a moderate to high sensitivity to acid deposition.

The geologic map of the EAFR (fig. 7) is based on work in the 7.5-min USGS Richmond Quadrangle (Mallard, 2000)

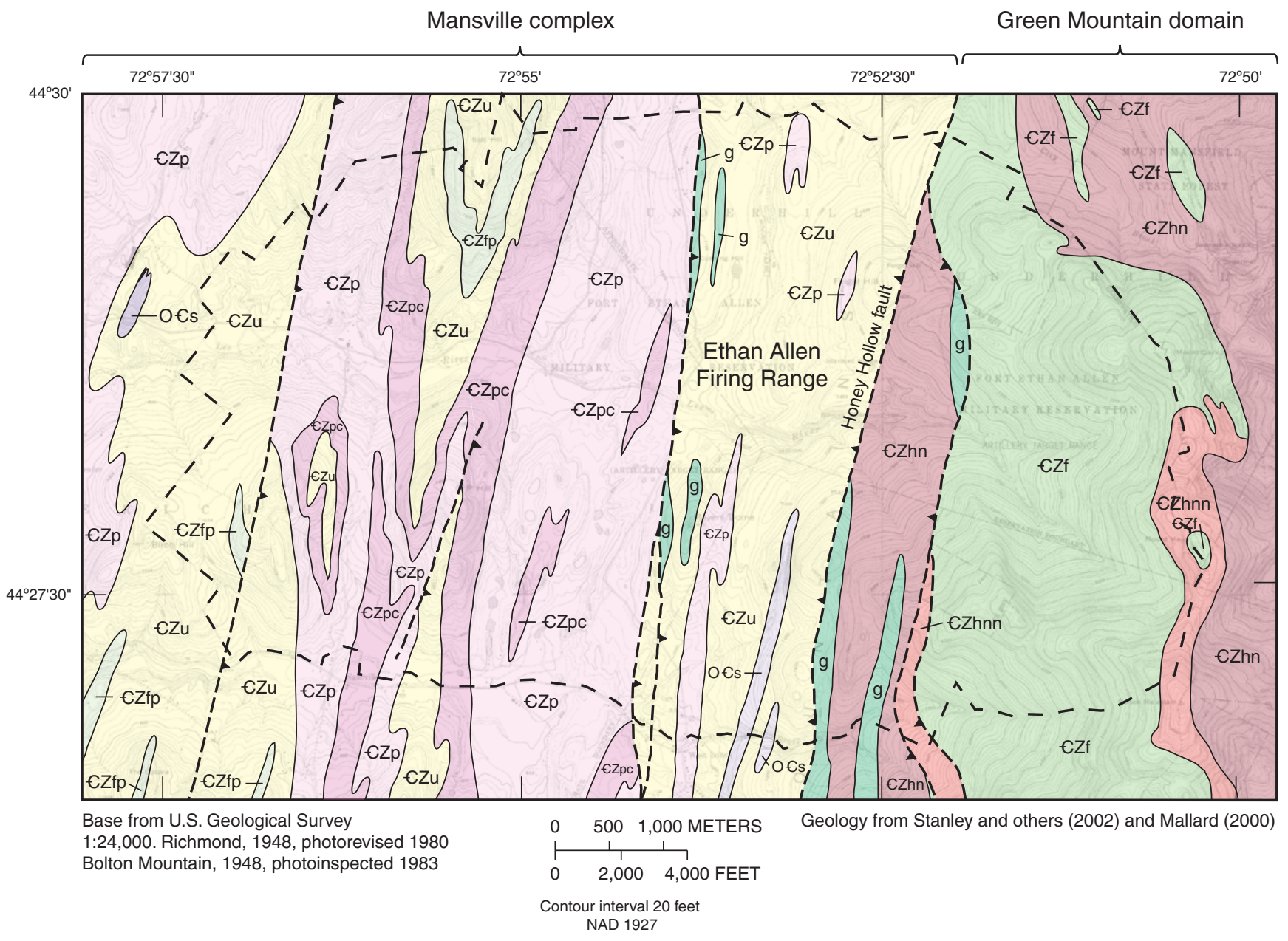

Figure 7. Bedrock geology at the Ethan Allen Firing Range in northern Vermont. 


\section{EXPLANATION \\ Bedrock geology from Stanley and others (2002) and Mallard (2000)}

Greenstone and amphobolite (age unknown)

g Thinly bedded, albite-epidote-carbonate greenstone and massive albite-amphibole-biotite-magnetite amphibolite; fine- to medium-grained, light- to dark-green amphibole-albite-chlorite-epidote schist; coarse-grained, dark-green, weakly foliated amphibole-albite-biotite-epidote amphibolite

\section{Sweetsburg Formation (Ordovician and Cambrian)}

OEs Graphitic phyllite; graphitic, quartzitic phyllite and schist with tan-weathering layers and pods of gray dolostone and black quartzite

Hazens Notch Formation (Cambrian and Late Proterozoic)

CZhn Undifferentiated dark, rusty, graphitic quartz-chlorite-muscovite-biotite \pm garnet schist and gneiss; dark albite porphy roblasts, large euhedral pyrite, and beds of dark-gray foliated quartzite are common; includes dark, rusty schist without graphite

CZhnn Nongraphitic schist; rusty-weathering, nongraphitic, sulfidic, chlorite schist

Fayston Formation (Cambrian and Late Proterozoic)

CZf White albitic schist; silvery-green, medium-grained, muscovite-quartz-chlorite-garnet-magnetite schist with thin, light-gray quartzite; medium- to coarse-grained, salt-and-pepper colored, quartz-albite-biotite-magnetite-pyrite schist and gneiss; silvery, dark-gray to rusty, medium-grained quartz-muscovite-albite-tourmaline-chlorite schist

Fairfield Pond Formation (Cambrian and Late Proterozoic)

$€ Z$ Light-gray to light-green quartz-sericite-chlorite phyllite \pm magnetite \pm biotite

Underhill Formation (Cambrian and Late Proterozoic)

$\mathrm{CZu}$ Silver-gray to silver-green, nongraphitic-chlorite-muscovite-quartz schist and phyllite, commonly with albite and magnetite \pm dolomite. Local lenses of white to pale-gray quartzite, quartz-albite granulite, and quartz-chlorite \pm biotite metawacke. Schist and phyllite dominate

Pinnacle Formation (Cambrian and Late Proterozoic)

CZp $\quad C Z p-S i l v e r-g r e e n$ to brown to olive-green pinstripe granofels (metawacke) and phyllite interlayered with small, visible clasts of quartz and feldspar; magnetic; granofels (metawacke) dominates. Locally contains greenstone, which is not mapped separately, and feldspathic, calcareous, amphibolitic mafic metavolcanic rock

CZpc, quartz-pebble conglomerate member; rounded, sorted, blue, white, and clear quartz pebbles ranging in size from 0.25 to 3 centimeters; occurs as lenses within massive metawacke or, locally, as bands of coarse-grained rock paralleling bands in the massive metawacke; grades across strike into the massive metawacke

Contact between bedrock units(from Stanley and others, 2002, and Mallard, 2000)

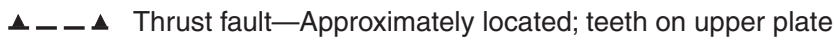

- _ - Ethan Allen Firing Range boundary

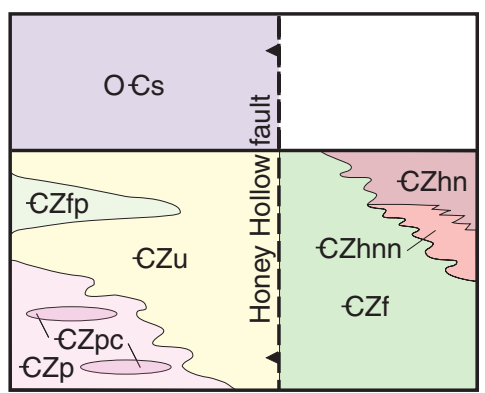

Correlation chart (after Mallard, 2000)

Figure 7. Continued. 
and on unpublished work in the 7.5-min USGS Bolton Quadrangle (Peter J. Thompson, University of New Hampshire, oral commun., 2004). Their maps have been compiled into a 1:100,000-scale map by the Vermont Geological Survey (Stanley and others, 2002). The geology for this report presented in figure 7 is reproduced from Stanley and others (2002) and Mallard (2000). Mallard (2000) has divided the Pinnacle and Underhill Formations into mapable units and identifies three stratigraphic sequences (Oak Hill group and Mansville complex (Mallard, 2000) and the Green Mountain domain) separated by two major fault complexes (West Fletcher fault and the Honey Hollow fault) that parallel the trend of regional schistosity. Two of the three fault-bounded stratigraphic packages, the Mansville complex, and Green Mountain domain, underlie EAFR and the Honey Hollow fault separates these stratigraphic packages. Minor faults are mapped where stratigraphic units are truncated. The Honey Hollow fault (fig. 7) was mapped as a west dipping, thrust fault (rocks of the Hazens Notch Formation thrust westward over rocks of the Pinnacle, Underhill, and Sweetsburg Formations, then folded to west-dipping) (Thompson and Thompson, 1992; Mallard, 2000).

Two structural domains defined by the fabric (schistosity) of the rock underlie the EAFR. The "central domain" (Mallard, 2000) underlies the western third of the study area. Here, schistosity trends north-south and is nearly vertical or dipping moderately to the east. "Large-scale antiforms and synforms control the map pattern (folding discontinuous lenses) within the western third of the EAFR" (Mallard, 2000). In the "eastern domain", schistosity trends north-northeast and dips moderately to steeply west and also dips moderately to the east (Mallard, 2000).

At the EAFR, the textural and compositional differences in the mapped bedrock units (Pinnacle and Underhill Formations) are enough to define mapable rock units, but are not great enough to create regional variations in ground-water flow in the bedrock aquifer among mapped units. Thick-bedded to massive granofels (wackes) of the Pinnacle Formation may be more likely to fracture (Peter J. Thompson, University of New Hampshire, oral commun., 2004); however, there were few fractures in cores from wells drilled into bedrock (fig. 2). Rock-quality designation (RQD) values (Deere and Deere, 1988) range from good (1 well) to excellent ( 2 wells) indicating little fracture. Outcrops of exposed bedrock also were not highly fractured. Structural features common to these rocks are described in the following paragraph. In some locations, structural features may control fracture formation, which can affect the permeability of the bedrock aquifer.

Three structural geologic deformations have affected the rocks that underlie EAFR. The first-deformation produced structures seldom seen within rocks at the EAFR. The second deformation produced the dominate schistosity in axial-plane orientation to isoclinal folds plunging either north or south. The second-deformation folds are generally sheared parallel to third-deformation cleavage. The second-deformation schistos- ity passes from east-dipping, through the vertical, to west-dipping across the area. The third deformation produced open upright folds, which plunge north or south at shallow amounts, and a spaced cleavage (Mallard, 2000).

\section{Glacial Sediments}

Glacial ice covered the region during the Wisconsinan glaciation between 90,000 and 12,000 years ago (Larsen, 1999). Sediments deposited in processes related to glaciation can be broadly grouped into till and stratified drift (fig. 8). Till is an unsorted mixture of rock fragments ranging in size from boulders $2-3 \mathrm{~m}$ in diameter to clay-size rock flour deposited beneath, or at, the margin of moving glacial ice. Stratified drift is composed of sediment moved by water (melting glacial ice) and deposited in water adjacent to glacial ice or at some distance from the ice. Because stratified drift is moved by water, the sediment is sorted and the deposits are layered. In general, well-sorted, coarse-textured (sand sized and greater) stratified drift has greater hydraulic conductivity and transmissivity than the generally poorly sorted, more compacted, till. The contact between till (unsorted to poorly sorted material) and stratified drift, consisting of sorted to well sorted, layered gravels, sands, silt and clay, ranges from approximately located (within about $60 \mathrm{~m}$ ) to inferred (within about $120 \mathrm{~m}$ ) (fig. 8). Various areas, originally covered by thin stratified sand and gravel and disturbed by the construction of firing ranges, are mapped on the basis of materials currently at land surface.

Till was deposited in a discontinuous fashion at the EAFR by southeastward advancing glaciers. Glaciers scoured calcareous rock material from the Lake Champlain Valley and incorporated some into till and outwash deposits at EAFR. Tills generally have a high silt or clay content and, therefore, have a low hydraulic conductivity. Hydraulic conductivities of about $0.3 \mathrm{~m} / \mathrm{d}$ are common for tills in New England (Mack, 1995; Melvin and others, 1992) (table 3). Where till contains more sand-sized sediment, its hydraulic conductivity and, therefore, transmissivity, can be greater. Tills in the EAFR area are usually less than $6 \mathrm{~m}$ thick and discontinuously cover the bedrock surface. Examination of well-completion reports (appendix 2) from areas surrounding the EAFR indicated that the thickness of till deposits are generally from 3 to $6 \mathrm{~m}$. Thick till (greater than $6 \mathrm{~m}$ thick) is found on north to west-facing slopes and thin till is found on bedrock ridges.

Stratified-drift deposits with varying characteristics can be broadly grouped into the following three settings in the study area: (1) high altitude coarse- and fine-grained ice-margin deposits, (2) intermediate altitude coarse-grained streamvalley deposits leading to fine-grained lake-margin deposits, and (3) low altitude valley-fill coarse- and fine-grained glacial-lake deposits (fig. 8). The horizontal hydraulic conductivities of stratified-drift deposits were estimated for similar deposits in Bristol, Vt. (Mack, 1995) and are listed in table 3 . The hydraulic conductivity of clay is very low and 


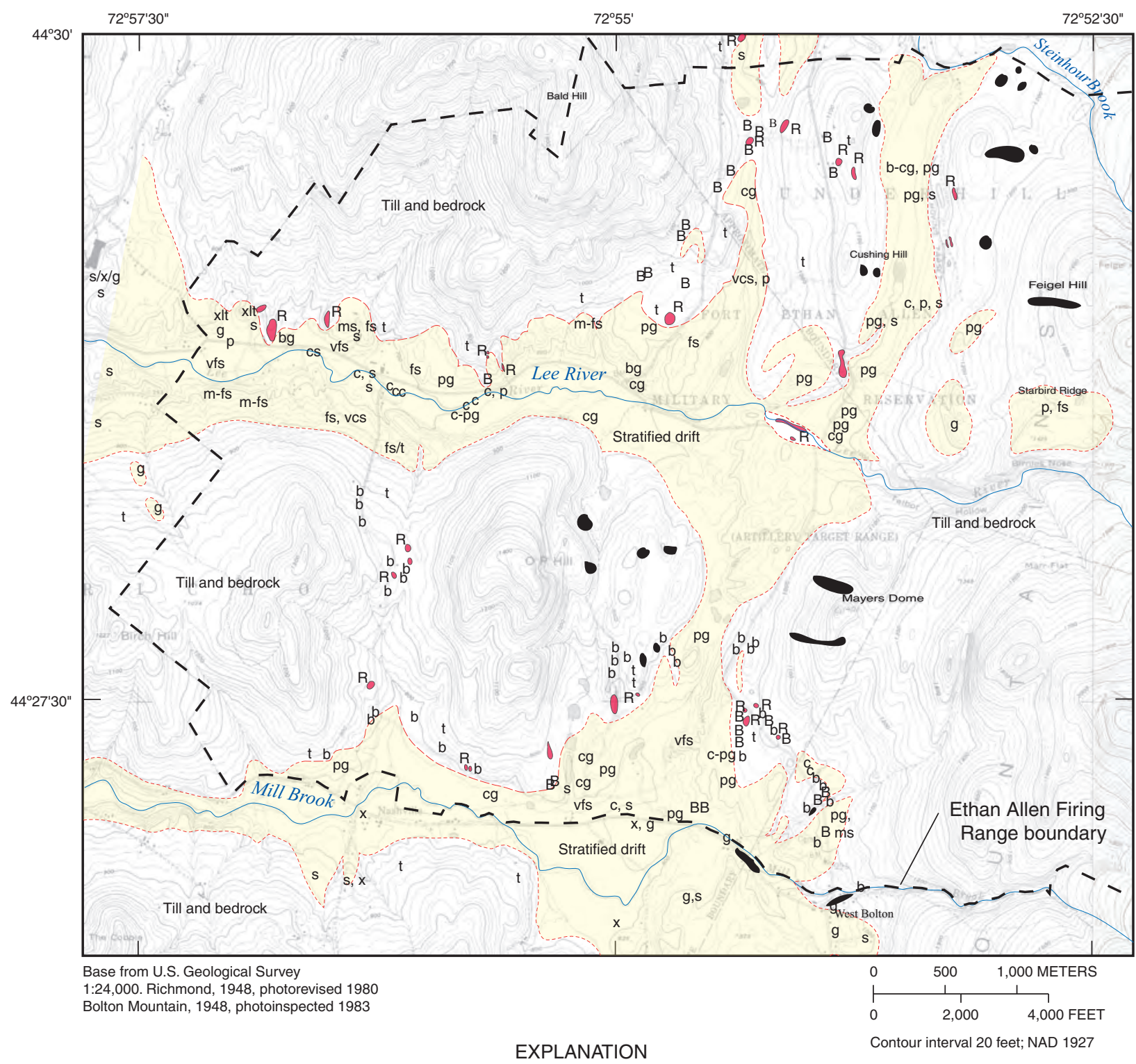

AREA OF POORLY SORTED UNCONSOLIDATED ICE-CONTACT MATERIALS AND SORTED TO VERY WELL SORTED STRATIFIED MATERIALS

OUTCROP

I R BEDROCK OUTCROP MAPPED IN THIS STUDY

- SELECTED BEDROCK OUTCROP LOCATED BY PREVIOUS STUDY

ETHAN ALLEN FIRING RANGE BOUNDARY

STRATIFIED-DRIFT CONTACT

SURFICIAL MATERIAL FOUND AT LAND SURFACE IN GENERAL LOCATION SHOWN

$\begin{array}{clcl}\text { B } & \text { Boulder greater than } 1 \text { meter in diameter } \\ \text { b } & \text { Boulder less than } 1 \text { meter in diameter } \\ \text { t } & \text { Till } & \text { cs } & \text { Coarse sand } \\ \text { c } & \text { Cobbles } & \text { s } & \text { Sand } \\ \text { p } & \text { Pebbles } & \text { ms } & \text { Medium sand } \\ \text { g } & \text { Gravel } & \text { fs } & \text { Fine sand } \\ \text { bg } & \text { Boulder gravel } & \text { vfs } & \text { Very fine sand } \\ \text { cg } & \text { Cobble gravel } & \text { xlt } & \text { Silt } \\ \text { pg } & \text { Pebble gravel } & \text { x } & \text { Clay } \\ \text { vcs } & \text { Very coarse sand } & & \end{array}$

Approximate within 0 to 60 meters of true contact Inferred within 0 to 120 meters of true contact

Figure 8. Surficial materials at the Ethan Allen Firing Range in northern Vermont. (Location of site shown in figure 1.) 
Table 3. Estimated horizontal hydraulic conductivity of aquifer materials in the region in northern Vermont from Mack (1995).

[mm, millimeters; $\mathrm{m} / \mathrm{d}$, meters per day; <, less than; >, greater than]

\begin{tabular}{lccc}
\hline Material type & $\begin{array}{c}\text { Mean grain size } \\
(\mathbf{m m})\end{array}$ & \multicolumn{2}{c}{$\begin{array}{c}\text { Estimated horizontal } \\
\text { hydraulic conductivity } \\
(\mathbf{m} / \mathbf{d})\end{array}$} \\
\cline { 3 - 4 } & & Median & Range \\
\hline Till & $<0.01-0.5$ & 0.3 & $<0.3-1.2$ \\
Sand, fine & .1 & 3 & $0.3-9.1$ \\
Sand, medium & .3 & 9 & $3-18$ \\
Sand, coarse & .7 & 36 & $18-61$ \\
Gravel & $2.0-4.0$ & 76 & $46->76$ \\
\hline
\end{tabular}

ranges from approximately 0.44 to $7.2 \times 10^{-5} \mathrm{~m} / \mathrm{d}$ (Freeze and Cherry, 1979).

Ice-marginal deposits, composed of discontinuous thin (less than $6 \mathrm{~m}$ thick) sheets of interbedded cobble gravel, pebble gravel, and sand overlie till and bedrock above altitudes of $361 \mathrm{~m}(1,185 \mathrm{ft})$. These deposits likely collected in glacial ice-marginal meltwater pools and channels on Feigle Hill, Starbird Ridge, and Mayers Dome. Meltwater drained southward through Bolton Notch as retreating ice blocked drainage to the west down the Lee River and Mill Brook Valleys.

Ice-marginal coarse-grained deposits grade into thicker, finer-grained deposits found at the head of the Mill Brook Valley and occur as thin sheets of sandy cobble-gravel and pebble-gravel near West Bolton. These form roughly flattopped terraces from altitudes of $326 \mathrm{~m}(1,070 \mathrm{ft})$ to $282 \mathrm{~m}$ $(925 \mathrm{ft})$. This material grades westward to interfinger with 6-21 m thick, stratified, fine- to medium-grained sand on west-facing slopes from $296 \mathrm{~m}$ (970 ft) to $282 \mathrm{~m}$ (925 ft) altitude. Locally, very fine sand and silt occur below $282 \mathrm{~m}$ (925 ft) altitude. Stratified drift was deposited between $274 \mathrm{~m}$ $(900 \mathrm{ft})$ and $305 \mathrm{~m}(1,000 \mathrm{ft})$ altitude along the southern side of the eastern end of the Lee River Valley. Fluvial ice-marginal cobble and pebble gravels deposited in thin sheets along the stream valleys east and west of Cushing Hill. Thick deposits of very fine sand at the east end of firing range 4-1 (fig. 2) formed as moving water from melting glacial ice entered a glacial lake in the Mill Brook Valley. Deposits of pebble gravel and sand southeast of Bald Hill along the north side of the Lee River Valley, ranging in altitudes from $274 \mathrm{~m}$ (900 ft) to $286 \mathrm{~m}$ $(940 \mathrm{ft})$, likely formed during this period.

Drilling logs from wells VT-JEW 127, VT-JEW 129, and VT-JEW 139 (appendix 1) show a pattern of very-fine sediment (clay) over coarse sands and gravel indicating various glacial lake levels in Mill Brook Valley. The fine sediment over coarse sediment is consistent with ice-margin deposits of coarse-grained glacial drift, deposited near westward retreating ice in the Mill Brook Valley, with clay deposited in the quiet water of the lake that formed as the ice withdrew. These stratified-drift sediments form a confined aquifer in places overlain by an unconfined aquifer that make up the stratifieddrift aquifers.

Glacial ice blocked the Lee River Valley at a point about $244 \mathrm{~m}$ (800 ft) east of well VT-JEW 124 (fig. 2). East of that point, terrace deposits rise to $274-\mathrm{m}$ (900-ft) altitude, and to $238 \mathrm{~m}$ (780 ft) to the west. West of that point, terraces are at 232-m (760-ft) altitude and valley-fill deposits are from 207-m (680-ft) to 213-m (700-ft) altitude. A diagrammatic hydrogeologic section representing the Lee River Valley deposits is presented in figure 9. Typical deposits, from land surface to till or bedrock, consist of 2-7 $\mathrm{m}$ of cobbles, pebbles, and coarse sand overlying 3-6 $\mathrm{m}$ of interfingering medium sand, very fine sand, silt, and $0-1 \mathrm{~m}$ of clay overlying boulders, cobbles, and very coarse sand (well logs VT-JEW 121, VT-JEW 134, VT-JEW 135, VT-JEW 123, VT-JEW 124, VT-JEW 125). This pattern of coarse over fine over coarsegrained deposits (fig. 9), indicates a glacial history similar to the Mill Brook Valley. As the glacier receded, coarse materials were deposited along the ice margins and a lake was formed. In the quiet lake environment, fine-grained materials settled to the lake bottom. A fluvial environment followed that quickly deposited coarse material over the fine-grained materials without eroding or removing the underlying lake deposits. This sequence of deposits formed a confined aquifer overlain by an unconfined aquifer.

\section{Aquifer Characteristics}

Wells are commonly drilled into bedrock for domestic supply in areas beyond the boundary of EAFR. Drillers' wellcompletion reports (Ken Yelsey, Vermont Agency of Natural Resources, written commun., 2004) for the towns of Jericho, Bottom, and Underhill (appendix 2) indicate that bedrockaquifer characteristics vary widely over short distances. However, median well depths are about $90 \mathrm{~m}$ (300 ft) deep and median short-term yields are about $23 \mathrm{~L} / \mathrm{min}(6 \mathrm{gal} / \mathrm{min})$. Characteristics of bedrock wells near the EAFR are most likely similar to those found in a statewide analysis of New Hampshire (Moore and others, 2002). The bedrock-aquifer characteristics inside the EAFR boundary are most likely similar to the general characteristics in Jericho and will include a wide range of hydraulic properties. For example, the supply well at the COGO facility has a reported yield of $11 \mathrm{~L} / \mathrm{min}$ and a depth of $98 \mathrm{~m}$. Bedrock borings drilled by this study were used to determine shallow bedrock properties, not to provide a water supply. The yield of the four bedrock-observation wells drilled for this investigation were generally low, less than $8 \mathrm{~L} / \mathrm{min}$ to near zero, and do not reflect regional bedrockaquifer characteristics. Bedrock hydraulic properties are likely similar to those found in New Hampshire (Mack, 2003; Tiedeman and others, 1998). The bulk (regional) bedrock hydraulic conductivity at the EAFR is likely to be about $0.3 \mathrm{~m} / \mathrm{d}$ or less.

Based on drillers' well-completion reports from Bolton, Jericho, and Underhill (Ken Yelsey, Vermont Agency of 


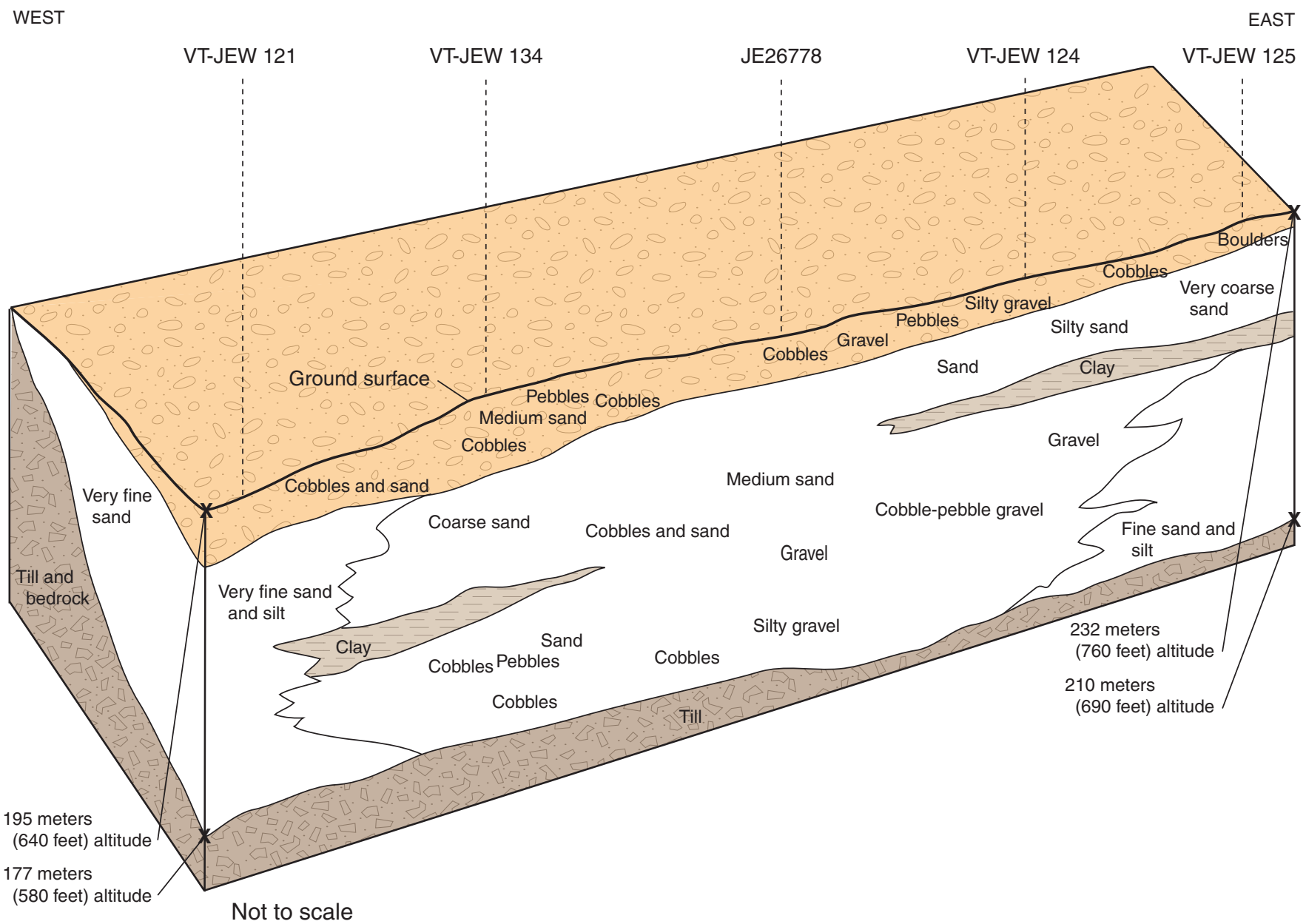

Figure 9. Hydrogeologic section of the Lee River Valley, Ethan Allen Firing Range in northern Vermont. (Location of wells shown in figure 2.)

Natural Resources, written commun., 2004), the static depth to water in the bedrock aquifer is commonly $3-6 \mathrm{~m}$ below land surface. Deeper depths to water (greater than $6 \mathrm{~m}$ ) are usually found at higher altitudes and ridges, whereas shallower depths to water are usually found in topographic depressions or near surface-water bodies. The ground-water potentiometric surface in the bedrock aquifer generally follows the land surface (Mack, 2003), and the direction of ground-water flow is from topographic highs to low areas. As a result of the generally low permeability of the bedrock aquifer, relative to glacial deposits, most of the ground water moving through the region will occur in the overlying glacial deposits.

The altitude of the water table (fig. 10) and the saturated thickness describe basic characteristics of the stratified-drift aquifers in the EAFR. In similar valley-fill stratified-drift aquifers in Vermont, water-level fluctuations (Keirstead and others, 2004) in stratified-drift aquifers are generally less than $2 \mathrm{~m}$ during the course of a year. The water table generally is $3 \mathrm{~m}$ below land surface (fig. 10). The 6-m (20-ft) contour interval provides an approximation of the regional water-table posi- tion. Water-table contours generally follow the land surface and indicate areas of recharge and discharge. For example, streams in the center of the valley in stratified-drift deposits generally drain the aquifer, and water-table contours bend, or "V", upstream. Where streams cross from till uplands into stratified-drift deposits, they generally lose water to the stratified-drift aquifer.

The overall direction of ground-water flow in the Lee River and Mill Brook Valleys (fig. 10) is east to west, while the localized flow is from the valley walls to the Lee River or Mill Brook in a north or south direction. A generalized representation of ground-water flow in a typical valley setting is shown in figure 11 .

The water-table altitude in the stratified-drift aquifer in the Lee River watershed ranges from just less than $195 \mathrm{~m}$ to more than $274 \mathrm{~m}$. In the Lee River watershed, the water-table gradient (a dimensionless unit measured as water-table change per length of land surface), down the center of the watershed, is moderate at about 0.0175 . The gradient at the valley walls and at the east end of the valley is much steeper. At the east 

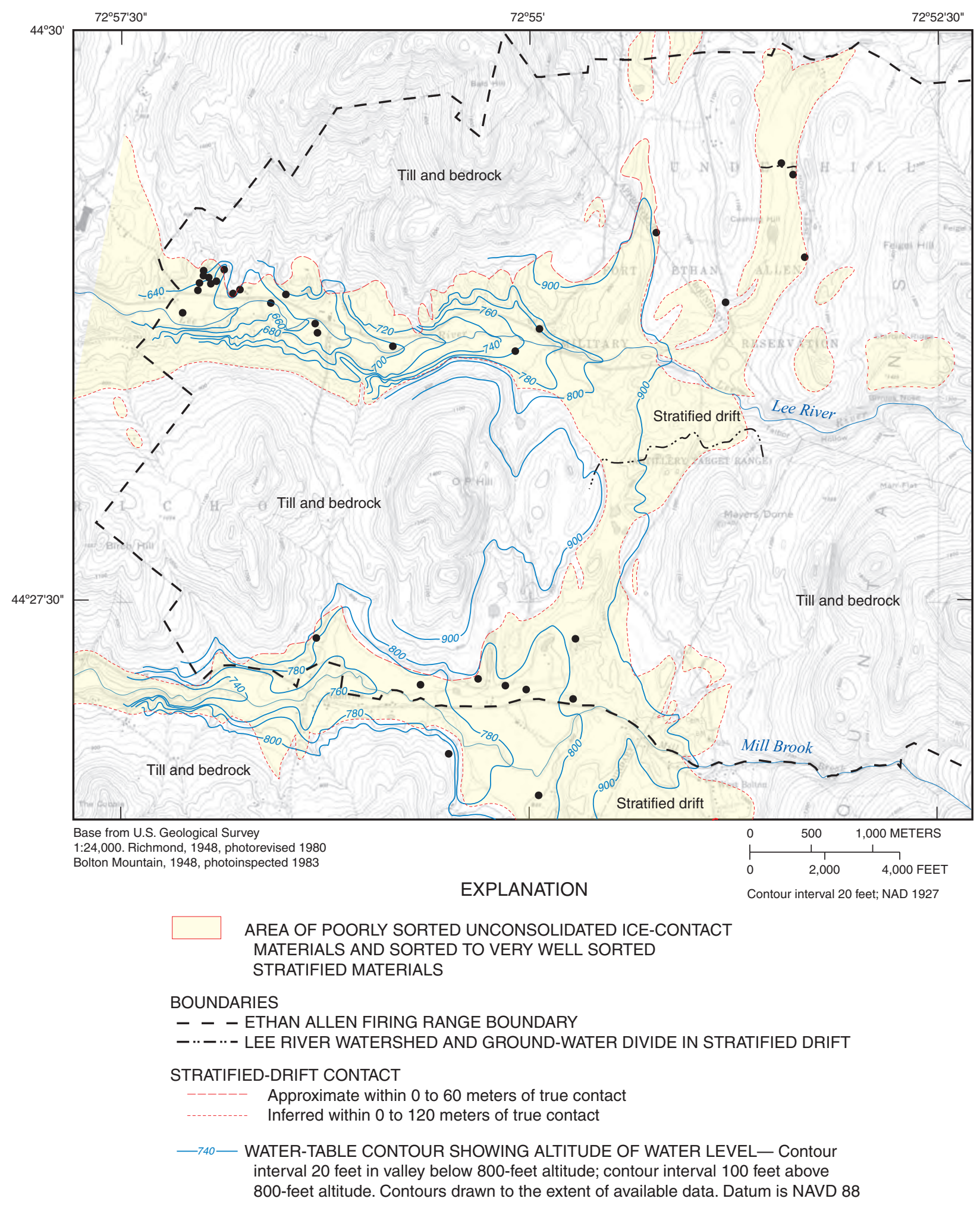

- WELL OR BORING

Figure 10. Generalized altitude of the water table in the Lee River and Mill Brook watersheds, Ethan Allen Firing Range in northern Vermont. (Location of site shown in figure 1.) 


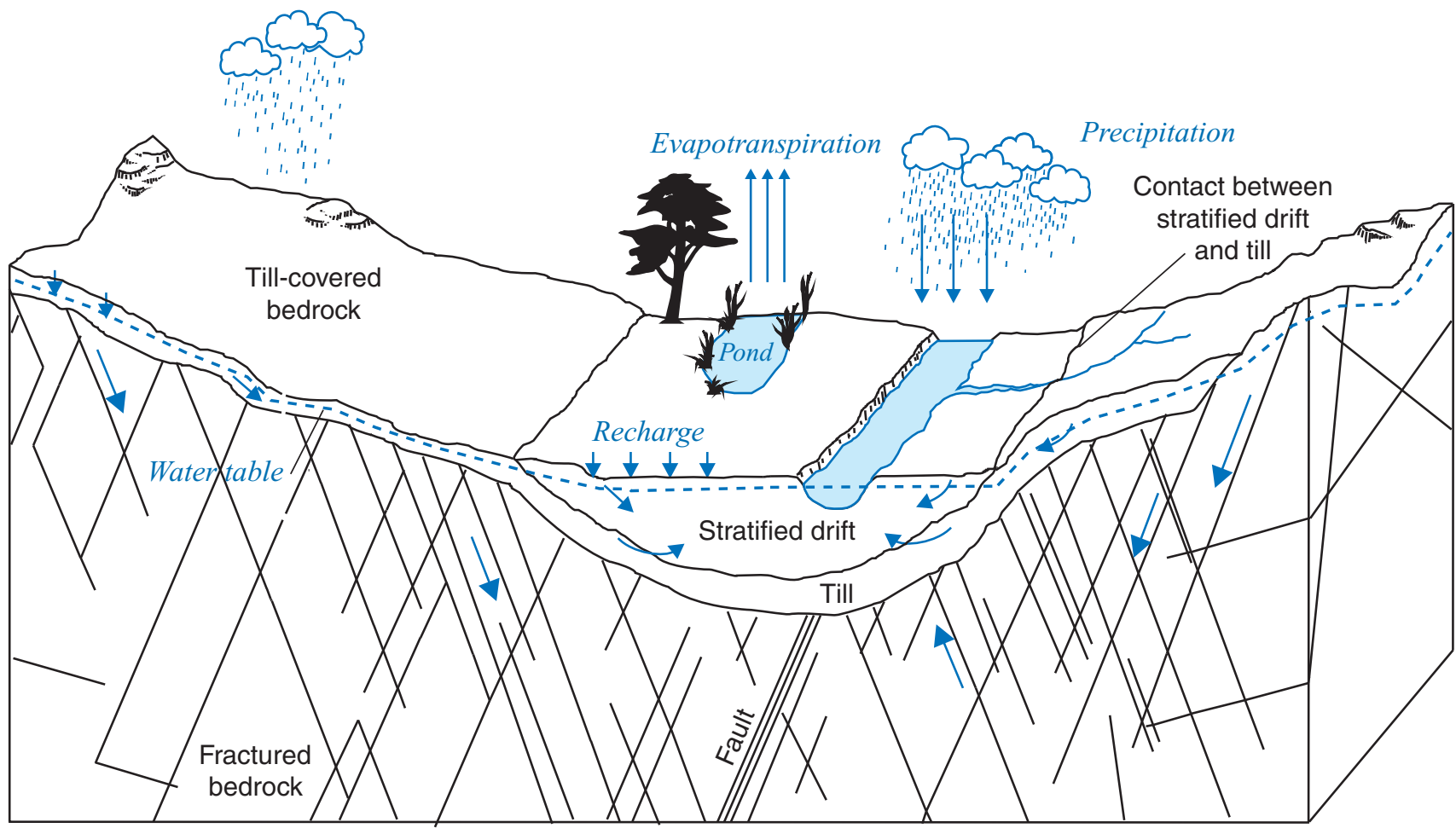

Figure 11. Generalized hydrogeologic section.

end of the Lee River and Mill Brook Valleys, the gradient is too steep to accurately contour the water table between the 243 and 274-m (800 and 900-ft) land-surface contours. In contrast, the water-table altitude in the Mill Brook watershed ranges from about 226 to more than $274 \mathrm{~m}$ and the overall gradient is relatively flat at 0.006 . The velocity of ground-water flow in the center of the Lee River Valley is estimated to be 0.2 to $0.6 \mathrm{~m} / \mathrm{d}$, which is caused by the steep gradient in the Lee River Valley and relatively coarse stratified drift (compared to other sediments). Because of the shallow gradient and generally fine-grained streambed sediments, the velocity of groundwater flow in the Mill Brook Valley is estimated to be $0.2 \mathrm{~m} / \mathrm{d}$ or less.

The saturated thickness of stratified drift in the Lee River and Mill Brook Valleys is shown in figure 12. Saturated thicknesses of about $18 \mathrm{~m}$ or more are found in the center of the Lee River and Mill Brook Valleys. Thick (more than $12 \mathrm{~m}$ ) saturated stratified-drift deposits are confined to a narrow area along the Lee River. Broad areas of thinly saturated (about $6 \mathrm{~m}$ or less) stratified drift are present towards the east end of the Lee River Valley (fig. 12). Thin stratified-drift deposits extend up the Lee River Valley into Underhill, between Cushing and Feigel Hills (fig. 12), and saturated thicknesses are likely to be less than $6 \mathrm{~m}$. Areas of thinly saturated (less than $6 \mathrm{~m}$ ), or unsaturated, stratified-drift deposits are present in the headwaters of the Lee River watershed (fig. 12). Most of the Impact Area (fig. 2) is expected to be thinly saturated to unsaturated stratified drift. At the northern EAFR boundary in Underhill, east of Range Road (fig. 12), are small areas of thinly saturated stratified drift. At the southern EAFR boundary along Mill Brook, drillers' well-completion reports indicate that stratified-drift deposits may be much greater than $18 \mathrm{~m}$ thick and, toward the east end of the valley, thick deposits may be more extensive.

\section{Water Quality}

Surface- and ground-water chemistry, streambed sediment, benthic macroinvertebrates, and fish-tissue samples were collected at the EAFR in June and July 2003. Results are compared to state and national water-quality guidelines and previous studies of the firing range (Goetz, 1999; Ward, 1999; Bouwkamp, 1992; Vermont Department of Environmental Conservation, 1988).

\section{Surface Water}

Stream-water samples were collected from sites SS-5, SS-6, SS-10, SS-11, and SS-12 (fig. 2, table 2) during moderate-flow conditions on June 4-5, 2003, and during low-flow conditions on July 30-31, 2003. Water-quality and physical characteristics of surface water are summarized in table 2 . 


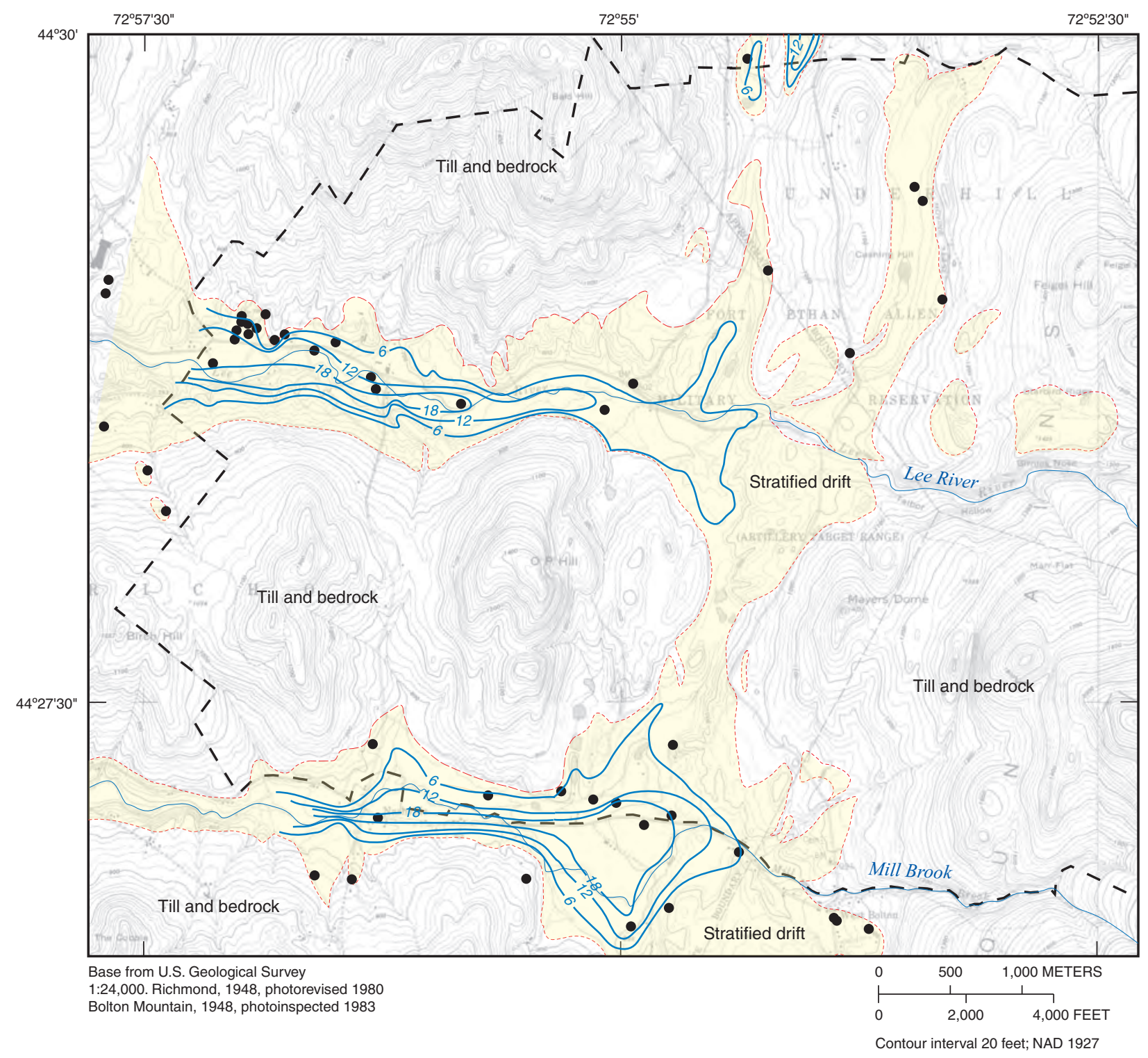

EXPLANATION

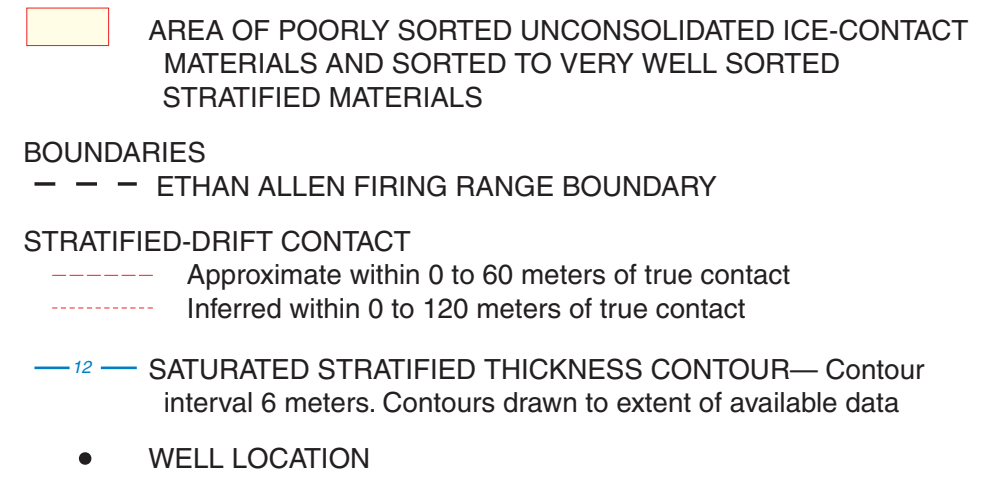

Figure 12. Generalized saturated thickness of stratified-drift deposits in the Ethan Allen Firing Range in northern Vermont. (Location of site shown in figure 1.) 
Surface-water samples had a median $\mathrm{pH}$ of 7.0 (neutral) and ranged from $\mathrm{pH} 6.8$ to $\mathrm{pH} 7.5$. Alkalinity ranged from 7.6 to $52 \mathrm{mg} / \mathrm{L}$ with a median value of $35 \mathrm{mg} / \mathrm{L}$. Dissolved oxygen concentrations were high $(7.5-10 \mathrm{mg} / \mathrm{L})$ at all sites except at site SS-10 (fig. 2), a low-gradient environment just below a beaver dam on a tributary to Mill Brook. Median specific conductance $(56 \mu \mathrm{S} / \mathrm{cm})$, turbidity $(0.2 \mathrm{NTU})$, and suspended solids $(0.8 \mathrm{mg} / \mathrm{L})$ were low (table 2$)$. Values for specific conductance, dissolved and suspended solids increased slightly from moderate- to low-flow conditions (table 2). VOCs and SVOCs (appendix 3) were not detected in any samples. Concentrations of major ions, trace elements, and nutrients in stream-water samples were well below USEPA drinking-water regulations and Canadian freshwater-quality guidelines for the protection of aquatic life (Canadian Council of Ministers of the Environment, 2003; U.S. Environmental Protection Agency, 2002a,b).

Concentrations of major ions, and trace elements, and nutrients in surface water are summarized in table 4. Concentrations of arsenic, cadmium, chromium, cobalt, copper, lead, nickel, uranium, and zinc were below detection levels for all samples. Barium, iron, manganese, and strontium were the only metals above reporting levels. Concentrations of iron and manganese were higher at the tributary to Mill Brook (SS-10, fig. 2) than other sampling sites. Nitrogen was present predominately as dissolved inorganic nitrogen, except at SS-10 (fig. 2), which is a tributary to the Mill River where wetlands around a beaver dam probably contributed higher dissolved ammonia plus organic nitrogen. Substantial differences in concentrations of major ions, trace elements, or nutrients were not observed between moderate (June) and low-flow (July) sampling conditions (table 4).

Surface water at the Mill Brook tributary (SS-10), Lee River tributary (SS-6), and Lee River outlet (SS-5) were compared with similar samples collected in 1992 and 1999 (table 5). Concentrations of major ions, trace elements, and nutrients at these 3 sites are relatively similar over the past 11 years. Most metal concentrations were below reporting levels. Concentrations of metals with detectable levels were lower in 1999 and 2003 than in 1992.

\section{Streambed Sediment}

Of the 23 major ions and trace elements analyzed in streambed sediment, 18 were detected in all 5 sediment samples (table 6). Molybdenum and sodium were not detected in any samples; antimony was detected in one sample, beryllium was detected in two samples, and selenium was detected in four samples. Concentrations of arsenic, cadmium, chromium, copper, lead, nickel, and zinc were well below streambed-sediment-quality guidelines for the probable adverse effects to aquatic life (MacDonald and others, 2000; Canadian Council of Ministers of the Environment, 2003). Streambed-sediment guidelines were not available for the other elements. Streambed-sediment samples collected at the Mill Brook tributary,
Lee River tributary, and Lee River outlet from the firing range were compared with similar samples collected in 1992 and 1999 (table 7). Substantial changes in concentrations were not noted over the 11 years. Generally higher concentrations in 2003 appear to be because of differences in particle-size distribution and organic content as indicated by percent moisture. Median moisture in streambed sediment was 71 percent in 2003, 36 percent in 1999, and 46 percent in 1992. Streambed sediments with high percent moisture generally have fine particle sizes and(or) high organic contents where trace elements tend to be concentrated (Brady, 1974).

\section{Biologic}

Biologic sampling was done to assess the overall surfacewater quality of the EAFR. Biological data included benthic macroinvertebrate samples, fish-tissue samples, and bacteria counts from surface and ground water. The results of these analyses are compared to investigations from 1988, 1992, and 1999. (Vermont Department of Environmental Conservation, 1988; Bouwkamp, 1992; Goetz, 1999; and Ward, 1999).

\section{Macroinvertebrates}

Benthic macroinvertebrates were collected on June 18, 2003, at four stream sites to assess the biologic health of the streams (appendix 4). Three sites were in the Lee River watershed (SS-5, SS-6, and SS-12) and one site was on Steinhour Brook (SS-11). Total abundance for the 4 sites sampled was 4,240 or 212 specimens per $0.09 \mathrm{~m}^{2}\left(1 \mathrm{ft}^{2}\right)$. The greatest abundance of specimens was found at the Lee River outlet from the firing range (SS-5, fig. 2). A total of 84 taxa were identified from the 4 sites. The greatest taxa richness was found at Steinhour Brook (SS-11, fig. 2) located in a relatively remote area in the northeastern corner of EAFR (fig. 2).

In addition to abundance and taxa richness, two numeric indexes were calculated to evaluate water quality. The EPT richness index is the total number of taxa in the pollution-intolerant members of Ephemeroptera, Plecoptera, and Trichoptera (EPT). The highest EPT richness index was found at Steinhour Brook (SS-11) indicating that this stream had the best aquatic habitats and highest biological health. A tributary to the Lee River (SS-6) had the lowest EPT richness index, possibly relating to the intermittent nature of this stream. The Hilsenhoff Biotic Index (HBI) was used to rate water quality based on abundance of pollution-tolerant and intolerant macroinvertebrate species (Hilsenhoff, 1987). All site samples collected in 2003 had HBI values between 2 and 2.5. On a scale from 0 to 10 , values from 0 to 3.5 are ranked as excellent water quality with no apparent organic pollution.

A comparison with historical data was done for the Lee River outlet (SS-5, fig. 2). The Vermont Department of Environmental Conservation (VTDEC) collected timed kick-net samples from about $0.5 \mathrm{mi}$ west of the EAFR boundary in 
Table 4a. Concentrations of dissolved major ions, trace elements, and nutrients in surface water during moderate and low-flow conditions at the Ethan Allen Firing Range in northern Vermont.

[Site locations shown on figure 2. Sample dates are in month, day and year ( $\mathrm{mm} / \mathrm{dd} / \mathrm{yy})$; All concentration units are in micrograms per liter $(\mu \mathrm{g} / \mathrm{L})$. The following compounds were below detection: aluminum, antimony, arsenic, beryllium, cadmium, chromium, cobalt, copper, lead, lithium, molybdenum, nickel, potassium, selenium, sodium, uranium, zinc; $\mathrm{J}=$ associated laboratory blank sample contains compound concentrations above method detection level but below reporting level, laboratory blank calcium concentrations are less than 3 percent of associated sample concentrations; $\mathrm{E}=$ estimated concentration, result less than reporting level; <, less than; --, no standard]

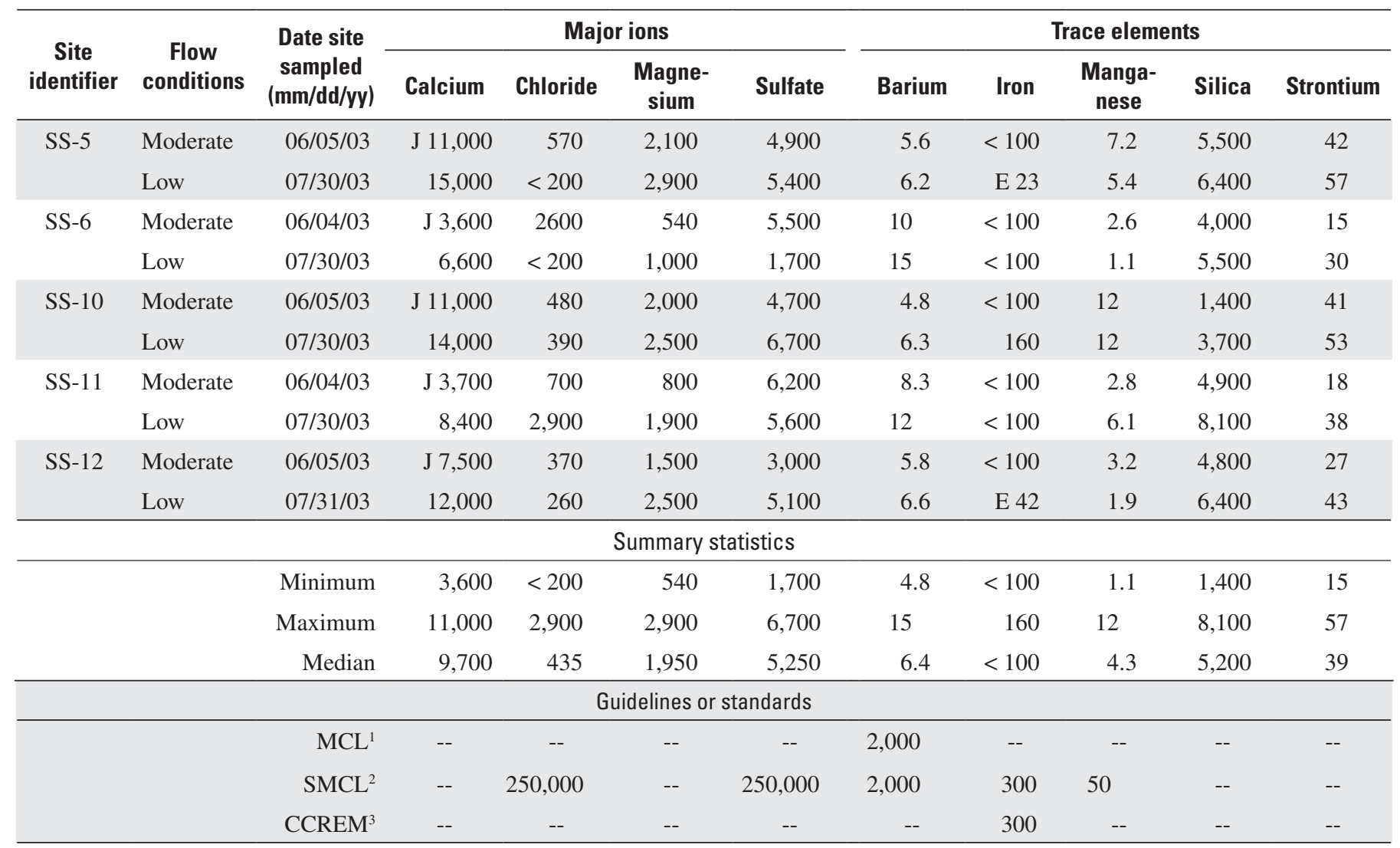

\footnotetext{
${ }^{1}$ Maximum Contaminant Level (MCL) established by the U.S. Environmental Protection Agency (2002a).

${ }^{2}$ Secondary Maximum Contaminant Level (SMCL) established by the U.S. Environmental Protection Agency (2002b).

${ }^{3}$ Canadian water-quality guidelines (CCREM) for the protection of freshwater aquatic life (Canadian Council of Resources and Environmental Ministers, 2003).
}

September 1988 (Vermont Department of Environmental Conservation, 1988). These data was compared to Surber samples collected east of the EAFR boundary in 1992 (Bouwkamp, 1992); 1999 (Ward, 1999), and July 2003. Because of differences in sampling methods (Surber and timed kick, and three replicates collected per sample in 1992 and 1999 compared to five replicates in 2003), the data are not directly comparable; however, data comparison still may indicate general changes in water quality. Taxa richness and EPT richness index were 38 and 21, respectively, in 2003 samples; 45 and 24.5, respectively, in 1988; 30 and 11, respectively, in 1992; and 20 and 13, respectively, in 1999 (fig. 13). These results probably indicate little change in the biological condition of the Lee River at the EAFR between 1988 and 2003. Any differences in taxa richness and EPT index are most likely the result of a combination of natural variability and sampling methods.

\section{Fish Tissue}

Whole-body-composite tissue samples of brook trout were collected at three stream sites; Steinhour Brook (SS-11, fig. 2), and two sites on the Lee River (SS-5 and SS-12, fig. 2). Of the 4 major ions and 19 trace elements analyzed for in fish tissue, 13 were detected in all 3 samples (table 8). Antimony, arsenic, beryllium, lithium, molybdenum, and uranium were not detected in any samples. Little difference in concentrations of trace elements was noted between samples below the Impact Area on Lee River (SS-12), at the outlet of Lee River from EAFR (SS-5), or from Steinhour Brook (SS-11). Concentrations of arsenic, cadmium, lead, nickel, and selenium in fish-tissue samples were well below USEPA screening criteria for protection of human health (U.S. Environmental Protection Agency, 1995) and(or) U.S. Food and Drug Administration (1993) "levels of concern" in shellfish. A comparison of 
Table 4b. Concentrations of nutrients in surface water during moderate and low-flow conditions at the Ethan Allen Firing Range in northern Vermont.

[Site locations shown on figure 2. The sample date is in month, day, year $(\mathrm{mm} / \mathrm{dd} / \mathrm{yy})$. All concentration units are in mg/L, milligrams per liter. $\mathrm{NO}_{3}$, Nitrate; $\mathrm{NO}_{2}$, Nitrite; The following compounds were below detection: aluminum, antimony, arsenic, beryllium, cadmium, chromium, cobalt, copper, lead, lithium, molybdenum, nickel, potassium, selenium, sodium, uranium, zinc; <, less than]

\begin{tabular}{|c|c|c|c|c|c|c|c|c|c|c|c|c|}
\hline \multirow[b]{2}{*}{$\begin{array}{l}\text { Site } \\
\text { identi- } \\
\text { fier }\end{array}$} & \multirow[b]{2}{*}{$\begin{array}{l}\text { Flow } \\
\text { condi- } \\
\text { tions }\end{array}$} & \multirow[b]{2}{*}{$\begin{array}{c}\text { Date site } \\
\text { sampled } \\
\text { (mm/dd/yy) }\end{array}$} & \multicolumn{10}{|c|}{ Nutrients } \\
\hline & & & $\begin{array}{c}\text { Total } \\
\text { ammo- } \\
\text { nia }\end{array}$ & $\begin{array}{c}\text { Dis- } \\
\text { solved } \\
\text { ammo- } \\
\text { nia }\end{array}$ & $\begin{array}{c}\text { Total } \\
\text { ammonia } \\
\text { plus } \\
\text { organic } \\
\text { nitrogen }\end{array}$ & $\begin{array}{c}\text { Dis- } \\
\text { solved } \\
\text { ammonia } \\
\text { plus } \\
\text { organic } \\
\text { nitrogen }\end{array}$ & $\begin{array}{c}\text { Total } \\
\mathrm{NO}_{3}+\mathrm{NO}_{2}\end{array}$ & $\begin{array}{c}\text { Dis- } \\
\text { solved } \\
\mathrm{NO}_{3}+\mathrm{NO}_{2}\end{array}$ & $\begin{array}{c}\text { Total } \\
\text { nitro- } \\
\text { gen) }\end{array}$ & $\begin{array}{l}\text { Dis- } \\
\text { solved } \\
\text { nitro- } \\
\text { gen }\end{array}$ & $\begin{array}{l}\text { Total } \\
\text { phos- } \\
\text { phorus }\end{array}$ & $\begin{array}{l}\text { Dis- } \\
\text { solved } \\
\text { ortho- } \\
\text { phos- } \\
\text { phate }\end{array}$ \\
\hline SS-5 & Low & 07/30/03 & $<.024$ & $<.024$ & $<.24$ & $<.24$ & .09 & .093 & .102 & .105 & $<.010$ & $<.010$ \\
\hline \multirow[t]{2}{*}{ SS-6 } & Moderate & 06/04/03 & .050 & .054 & $<.24$ & .24 & .013 & .011 & .063 & .251 & $<.010$ & .052 \\
\hline & Low & 07/30/03 & $<.024$ & $<.024$ & $<.24$ & $<.24$ & .098 & .095 & .098 & .095 & $<.010$ & $<.010$ \\
\hline \multirow[t]{2}{*}{ SS-10 } & Moderate & 06/05/03 & .06 & .047 & .41 & .37 & $<.010$ & $<.010$ & .410 & .375 & .011 & $<.010$ \\
\hline & Low & $07 / 30 / 03$ & .033 & .038 & .38 & .32 & $<.010$ & $<.010$ & .380 & .325 & .013 & $<.010$ \\
\hline \multirow[t]{2}{*}{ SS-12 } & Moderate & 06/05/03 & .034 & .032 & $<.24$ & $<.24$ & .037 & .031 & .071 & .063 & $<.010$ & $<.010$ \\
\hline & Low & $07 / 31 / 03$ & $<.024$ & $<.024$ & $<.24$ & $<.24$ & .091 & .059 & .091 & .059 & $<.010$ & $<.010$ \\
\hline \multicolumn{13}{|c|}{ Summary statistics } \\
\hline & & Minimum & $<0.024$ & $<0.024$ & $<0.24$ & $<0.24$ & $<0.010$ & $<0.010$ & 0.063 & 0.063 & $<0.010$ & $<0.010$ \\
\hline & & Maximum & .06 & .054 & .41 & .37 & .140 & .140 & .410 & .375 & .013 & .052 \\
\hline & & Median & .033 & .029 & $<.24$ & $<.24$ & .061 & .046 & .106 & .110 & $<.010$ & $<.010$ \\
\hline
\end{tabular}

brook-trout samples, collected at the outlet of the firing range in 1992 (Bouwkamp, 1992) and 2003, indicates metal concentrations may have decreased over the past 11 years (table 9). Concentrations of cadmium, chromium, copper, and lead were all about an order-of-magnitude lower in 2003 than in 1999.

Concentrations of aluminum, selenium, and zinc were similar in 2003 to 1992 samples, only iron was 3 times higher in 2003 sample. Because some of the brook trout caught in 2003 may have been stocked, a sample of brown trout (a species of fish not commonly stocked) collected in 2003 is included in the comparison. Similar concentrations of trace elements in fish tissues of brown and brook trout collected in 2003 most likely indicate that the lower trace-metal concentrations in the brook-trout samples are not an artifact of fish stocking. Native, reproducing (non-stocked) trout found at the site generally indicates high-quality water.

\section{Bacteria}

Fecal indicator bacteria, Escherichia coli (E-coli), in water indicates the possible presence of pathogens. E-coli concentrations in water samples were well below the State of Vermont ( 77 counts $/ 100 \mathrm{~mL}$ ) swimming guidelines at all five stream sites at moderate- and low-flow conditions, and all 10 ground-water observation wells (Vermont Water Resource Board, 2004). E-coli counts were higher in stream samples during low-flow conditions (median $20 / 100 \mathrm{~mL}$ ) than during moderate-flow conditions (median $<10 / 100 \mathrm{~mL}$ ). E-coli counts were above detection levels $(10 / 100 \mathrm{ml})$ at four surface-water sites (SS-5, SS-6, SS-10, SS-11) during low-flow conditions, and above detection levels at moderate-flow conditions at one site directly below a beaver dam (SS-10). Any detection of $E$-coli warrants concern for potable waters (Wilde and others, 1998). E-coli were not detected in ground-water samples. 


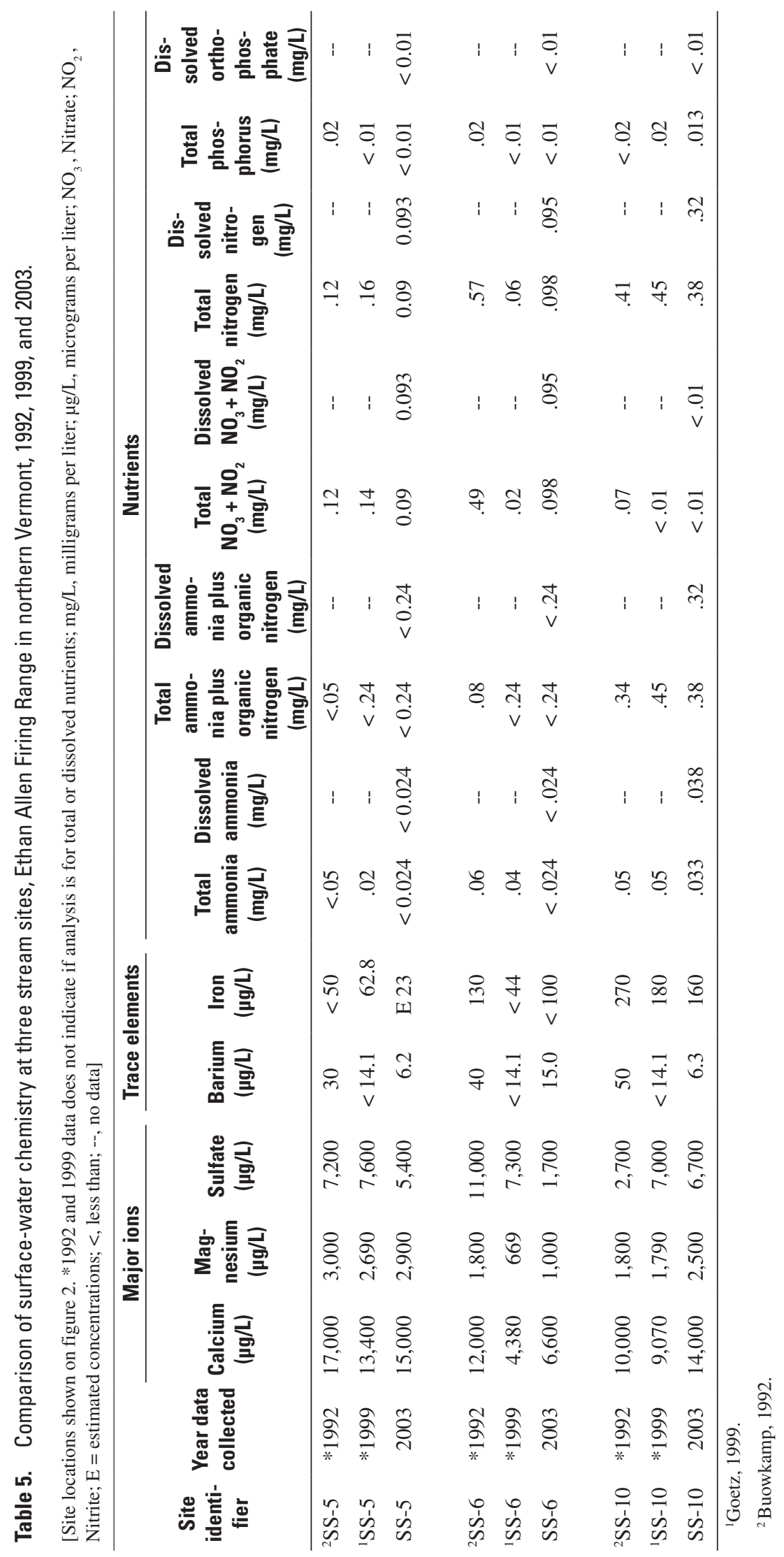


Table 6. Concentrations of major ions and trace elements in streambed sediment at the Ethan Allen Firing Range in northern Vermont.

[Site locations are shown on figure 2. The sample date is in month, day, year $(\mathrm{mm} / \mathrm{dd} / \mathrm{yy})$. Concentration units are in $\mathrm{mg} / \mathrm{kg}$, milligrams per kilogram dry weight. $\mathrm{E}=$ estimated result, result is less than reporting level; $\mathrm{J}=$ associated laboratory blank sample contains compound concentrations above method detection level but below reporting level, laboratory blank concentrations are less than 0.1 percent of associated sample concentrations; $\mathrm{ND}=\mathrm{not}$ detected at method detection level; Molybdenum, and sodium were below method detection levels in all samples; --, no standard]

\begin{tabular}{|c|c|c|c|c|c|c|c|c|c|c|c|c|}
\hline $\begin{array}{c}\text { Site } \\
\text { identifier }\end{array}$ & $\begin{array}{c}\text { Date site } \\
\text { sampled } \\
\text { (mm/dd/yy) }\end{array}$ & $\begin{array}{l}\text { Moisture } \\
\text { (percent) }\end{array}$ & \multicolumn{3}{|c|}{ Major ions } & \multicolumn{7}{|c|}{ Trace elements } \\
\hline SS-6 & $07 / 04 / 03$ & 71 & J 3,500 & 3,700 & 1,500 & $\mathrm{~J} 15,000$ & Е 0.36 & E 2.2 & J 84 & Е 0.87 & E.76 & J 13 \\
\hline SS-10 & $07 / 04 / 03$ & 73 & $\mathrm{~J} 4,700$ & 2,400 & E 800 & J 6,800 & ND & E 1.0 & J 38 & ND & E. 29 & J 7.6 \\
\hline SS-12 & 07/04/03 & 84 & J 7,500 & 3,600 & E 1,500 & J 12,000 & ND & E 3.4 & $\mathrm{~J} 110$ & $\mathrm{ND}$ & E 1.20 & $\mathrm{~J} 14$ \\
\hline \multicolumn{13}{|c|}{ Summary statistics } \\
\hline Minimum & -- & 60 & 3,500 & 2,400 & 800 & 6,800 & ND & 1.0 & 38 & ND & 0.29 & 7.6 \\
\hline Maximum & -- & 84 & 7,500 & 3,700 & 1,500 & 15,000 & 0.36 & 3.4 & 110 & 0.87 & 1.20 & 14 \\
\hline
\end{tabular}

Table 6. Concentrations of major ions, and trace elements in streambed sediment at the Ethan Allen Firing Range in northern Vermont.-Continued

[Site locations are shown on figure 2. The sample date is in month, day, year ( $\mathrm{mm} / \mathrm{dd} / \mathrm{yy})$. Concentration units are in $\mathrm{mg} / \mathrm{kg}$, milligrams per kilogram dry weight. $\mathrm{E}=$ estimated result, result is less than reporting level; $\mathrm{J}=$ associated laboratory blank sample contains compound concentrations above method detection level but below reporting level, laboratory blank concentrations are less than 0.1 percent of associated sample concentrations; ND = not detected at method detection level; Molybdenum, and sodium were below method detection levels in all samples; --, no standard]

\begin{tabular}{|c|c|c|c|c|c|c|c|c|c|c|c|c|}
\hline $\begin{array}{c}\text { Site } \\
\text { identifier }\end{array}$ & $\begin{array}{l}\text { Date site } \\
\text { sampled } \\
\text { (mm/dd/yy) }\end{array}$ & \multicolumn{11}{|c|}{ Trace elements } \\
\hline SS-6 & 07/04/03 & J 24 & J 16 & J 21,000 & J 12 & 19 & $\mathrm{~J} 1,000$ & J 20 & E 1.1 & $\mathrm{~J} 20$ & E 1.4 & 150 \\
\hline SS-10 & 07/04/03 & J 4.9 & J 9.4 & J 12,000 & J 12 & E 9.6 & J 210 & J 7.6 & ND & $\mathrm{J} 20$ & E.72 & 50 \\
\hline SS-12 & 07/04/03 & J 17 & J 19 & J 26,000 & J 17 & E 16 & J 2,800 & J 19 & E 1.9 & J 34 & E 2.0 & 140 \\
\hline \multicolumn{13}{|c|}{ Summary statistics } \\
\hline & Minimum & 4.9 & 9.4 & 12,000 & 9.5 & 9.6 & 210 & 7.6 & ND & 18 & 0.72 & 50 \\
\hline & Maximum & 24 & 19 & 26,000 & 17 & 19 & 2,800 & 20 & 1.9 & 34 & 2.0 & 150 \\
\hline
\end{tabular}

${ }^{1}$ Canadian water-quality guidelines (CCREM) for the protection of freshwater aquatic life (Canadian Council of Resources and Environmental Ministers, 2003). 


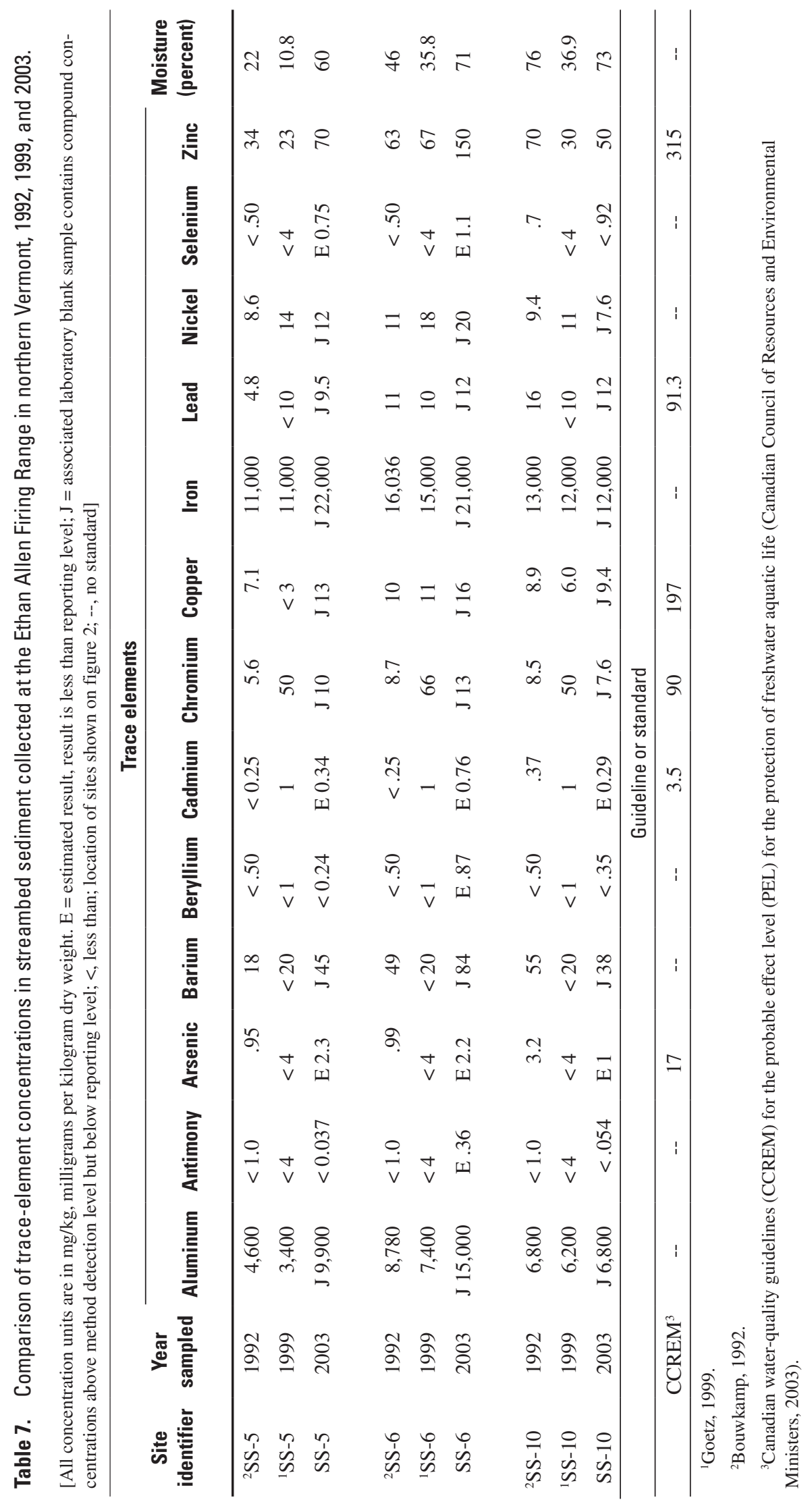



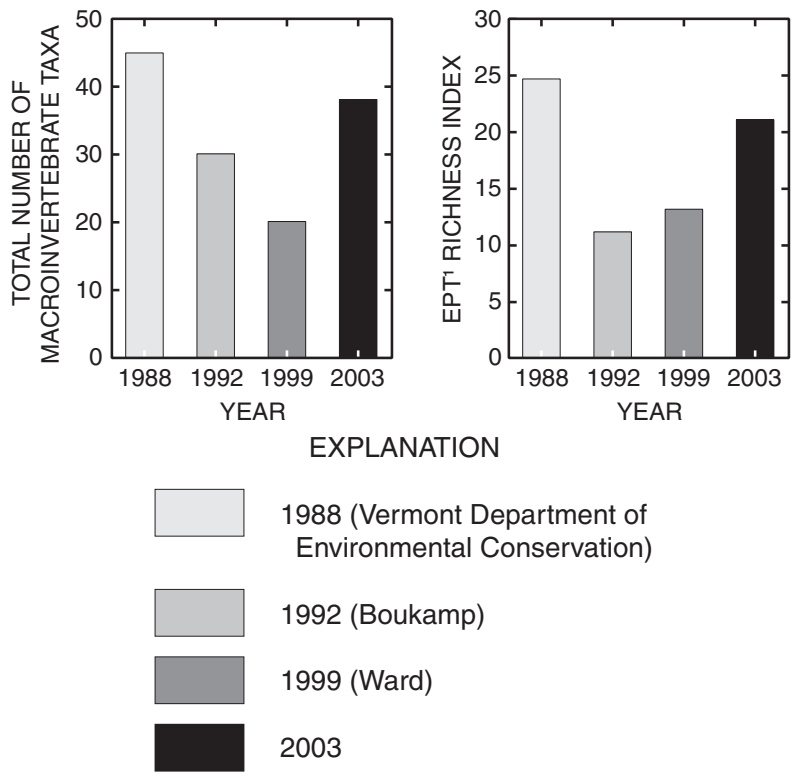

\section{EXPLANATION}

1988 (Vermont Department of Environmental Conservation)

1992 (Boukamp)

1999 (Ward)

2003

${ }^{1}$ Ephemeroptera, Plecoptera, and Trichoptera

Figure 13. Comparison of macroinvertebrate taxa and Ephemeroptera, Plecoptera, and Trichoptera (EPT) richness index collected over a 15-year span from the Lee River at the outlet of the Ethan Allen Firing Range (SS-5) in northern Vermont.

Table 8. Concentrations of major ions and trace elements in fish tissue at the Ethan Allen Firing Range in northern Vermont.

[Site locations are shown on figure 2. The sample date is in month, day, year $(\mathrm{mm} / \mathrm{dd} / \mathrm{yy})$. Units are in $\mathrm{mg} / \mathrm{kg}$ wet weight, milligrams per kilogram. Samples are five fish composites of 5 to 7.5 inch long brook trout (Salvenlinus fontinalis). $\mathrm{E}=$ estimated result, result is less than reporting level; $\mathrm{J}=$ associated laboratory blank sample contains compound concentrations above method detection level but below reporting level, laboratory blank strontium and calcium concentrations are less than 3 percent of associated sample concentrations, laboratory blank chromium concentrations are less than 18 percent of associated sample concentrations; antimony, arsenic, beryllium, lithium, molybdenum, and uranium concentrations were below method detection levels in all samples.]

\begin{tabular}{|c|c|c|c|c|c|c|c|c|c|}
\hline Site identifier & $\begin{array}{l}\text { Date site } \\
\text { sampled } \\
\text { (mm/dd/yy) }\end{array}$ & \multicolumn{4}{|c|}{ Major ions } & \multicolumn{4}{|c|}{ Trace elements } \\
\hline SS-11 & 06/10/03 & $\mathrm{J} 7,000$ & 370 & 3,600 & 700 & 32 & 1.10 & E.068 & $\mathrm{J} .4$ \\
\hline SS-12 & 06/11/03 & $\mathrm{J} 2,000$ & 240 & 2,800 & 650 & 29 & E .45 & E.046 & J .38 \\
\hline
\end{tabular}

\begin{tabular}{|c|c|c|c|c|c|c|c|c|c|c|}
\hline \multirow{2}{*}{ Site identifier } & \multirow{2}{*}{$\begin{array}{l}\text { Date site } \\
\text { sampled } \\
\text { (mm/dd/yy) }\end{array}$} & \multicolumn{9}{|c|}{ Trace elements } \\
\hline & & Cobalt & Copper & Iron & Lead & Manganese & Nickel & Selenium & Strontium & Zinc \\
\hline $\mathrm{SS}-5$ & 06/10/03 & Е 0.06 & 1.3 & 42 & E 0.021 & 5.8 & E 0.08 & 0.53 & J 9.9 & 25 \\
\hline SS-11 & 06/10/03 & .17 & 1.1 & 87 & E.08 & 8.8 & .23 & E.46 & J 9.3 & 39 \\
\hline SS-12 & 06/11/03 & .11 & 1.3 & 79 & E. .034 & 4.1 & .12 & .52 & J 2.8 & 18 \\
\hline
\end{tabular}


Table 9. Comparison of trace-element concentrations in fish tissue from the Lee River at the Ethan Allen Firing Range in northern Vermont.

[Site locations are shown in figure 2. All concentration units are in milligrams per kilogram (mg/kg) wet weight. Site SS-5 2003 sample is a 5-fish composite of 6 to 7 inch long brook trout (Salvenlinus fontinalis); Site SS-5 2003 Duplicate is a 5-fish composite of 5-10 inch long brown trout (Salmo tratta); Site SS-5 1992 sample is a composite of 3-6 inch long brook trout (Salvenlinus fontinalis); E = estimated result, result is less than reporting level; $\mathrm{J}=$ associated laboratory blank sample contains compound concentrations above method detection level but below reporting level; $\mathrm{ND}=$ not detected at method detection level; $<$, less than]

\begin{tabular}{|c|c|c|c|c|c|c|c|c|c|}
\hline \multirow{2}{*}{ Site identifier } & \multirow{2}{*}{$\begin{array}{c}\text { Year } \\
\text { sampled }\end{array}$} & \multirow{2}{*}{ Species } & \multicolumn{7}{|c|}{ Trace elements } \\
\hline & & & Aluminum & Antimony & Arsenic & Barium & Beryllium & Cadmium & Chromium \\
\hline${ }^{1} \mathrm{SS}-5$ & 1992 & Brook trout & 21.5 & $<2$ & $<100$ & $<1.97$ & 0.197 & .182 & 7.03 \\
\hline SS-5 & 2003 & Brook trout & E 9.6 & ND & ND & E 0.59 & ND & E 0.039 & J 0.32 \\
\hline DUPLICATE & 2003 & Brown trout & 100 & ND & ND & E.91 & ND & Е .038 & J .78 \\
\hline
\end{tabular}

\begin{tabular}{cccccccccc}
\hline \multirow{2}{*}{ Site identifier } & \multirow{2}{*}{$\begin{array}{c}\text { Year } \\
\text { sampled }\end{array}$} & Species & \multicolumn{5}{c}{ Trace elements } \\
\cline { 4 - 9 } & & Copper & Iron & Lead & Nickel & Selenium & Zinc \\
\hline${ }^{1}$ SS-5 & 1992 & Brook trout & 14.3 & 14.3 & 3.78 & $<9.85$ & .53 & 37 \\
SS-5 & 2003 & Brook trout & 1.3 & 42 & E 0.021 & 0.08 & 0.53 & 25 \\
DUPLICATE & 2003 & Brown trout & 1.3 & 310 & E .061 & .99 & E .47 & 16 \\
\hline
\end{tabular}

${ }^{1}$ Buowkemp, 1992.

\section{Ground Water}

Ten ground-water samples were collected in July 2003 from wells in stratified-drift aquifers (fig. 2) in the Lee River and Mill Brook watersheds. The bedrock wells installed for this study were low yielding (generally less than $0.06 \mathrm{~L} / \mathrm{s}$ ) and may not have provided water-quality samples representative of bedrock water-supply wells in the region. Water-quality and physical characteristics of ground water are summarized in table 10. Ground water in most wells was slightly alkaline, $\mathrm{pH}$ ranged from 6.1 to 8.3 with a median of 7.5. Alkalinities in ground water (median $75 \mathrm{mg} / \mathrm{L}$ ) were higher than in surface water (median $35 \mathrm{mg} / \mathrm{L}$, table 2). The high alkalinities reflect the carbonate nature of some glacially derived source rock materials from the Lake Champlain Valley to the northwest. Dissolved oxygen concentrations were variable for ground water, ranging from 0.4 to 7.8 with a median value of $3.3 \mathrm{mg} / \mathrm{L}$. Specific conductance, suspended solids, and turbidity (median $161 \mu \mathrm{S} / \mathrm{cm}, 49 \mathrm{mg} / \mathrm{L}$, and $22 \mathrm{NTU}$, respectively) were slightly higher in ground water than in surface water. Values of dissolved solids (median $97 \mathrm{Mg} / \mathrm{L}$, table 10) were similar to values measured in surface water (median $79 \mathrm{mg} / \mathrm{L}$, table 2).

Concentrations of half of the 14 trace elements analyzed (arsenic, cadmium, chromium, lead, nickel, uranium, and zinc) were below detection levels. Barium, cobalt, copper, iron, manganese, molybdenum, and strontium were the only metals detected in ground-water samples (table 11). Cobalt (3.1 and $2.5 \mu \mathrm{g} / \mathrm{L})$ and iron (230 and 27,000 $\mu \mathrm{g} / \mathrm{L})$, and were detected only at 2 wells (VT-JEW 127 and VT-JEW 129) near Mill Brook, and copper $(2 \mu \mathrm{g} / \mathrm{L})$ was detected at one of these wells (VT-JEW 127). These same two wells also had higher concentrations of barium and manganese (from 2 to 10 times greater) than other ground-water samples. The higher concentrations of these trace elements are believed to be natural occurrences. The low occurrence of metals in ground water is probably due, in part, to the buffered nature (high alkalinity) and high $\mathrm{pH}$ of ground water in the EAFR stratified-drift aquifers.

Concentrations of nutrients in ground water were at or below detection levels in most samples (table 12). Ammonia and ammonia plus organic nitrogen were only found in ground-water samples in the Mill Brook watershed. Wetlands and beaver ponds in this low-gradient watershed may explain the presences of organic nitrogen in both surface and ground water in this area. Total inorganic nitrogen was essentially all dissolved, ranging from below detection (0.010) to $0.26 \mathrm{mg} / \mathrm{L}$. Phosphorus was associated with suspended sediments, and concentrations ranged from below detection $(0.010)$ to $0.43 \mathrm{mg} / \mathrm{L}$.

Ground-water chemistry in the Mill Brook watershed, a low-gradient environment, generally had higher concentrations of dissolved trace elements and organic nitrogen than the Lee River watershed, a high-gradient environment. Concentrations of trace elements and nutrients were below USEPA drinkingwater standards for all except one constituent in one well. The concentration of iron in a well sample (VT-JEW 129) from the Mill Brook watershed was $27,000 \mu \mathrm{g} / \mathrm{L}$ (table 11), well above the $300 \mu \mathrm{g} / \mathrm{L}$ USEPA safe drinking-water guideline. VOCs and SVOCs (appendix 2) were not detected in any samples. 
Table 10. Summary of physical properties and water-quality characteristics of ground water at the Ethan Allen Firing Range in northern Vermont.

[Site locations shown on figure 2. The sample date is in month, day, year ( $\mathrm{mm} / \mathrm{dd} / \mathrm{yy})$. EC, specific conductance, in $\mu \mathrm{S} / \mathrm{cm}$, microsiemens per centimeter; ${ }^{\circ} \mathrm{C}$, degrees Celsius; NTU, nephelometric turbity units; DO, dissolved oxygen; mg/L, milligrams per liter; --, no standard]

\begin{tabular}{|c|c|c|c|c|c|c|c|c|c|c|}
\hline Site identifier & $\begin{array}{c}\text { Date site } \\
\text { sampled } \\
\text { (mm/dd/yy) }\end{array}$ & \multicolumn{6}{|c|}{ Physical properties } & \multicolumn{3}{|c|}{ Water-quality characteristics } \\
\hline VT-JEW 121 & 07/24/03 & 103 & 6.55 & 9.4 & 3.8 & 6.70 & 38 & 78 & 45.5 & 67 \\
\hline VT-JEW 123 & 07/25/03 & 323 & 7.57 & 10.0 & 3.0 & .55 & 138 & 173 & 5.1 & 160 \\
\hline VT-JEW 125 & 07/25/03 & 173 & 8.10 & 9.3 & 16.3 & .45 & 82 & 104 & 39.8 & 109 \\
\hline VT-UHW 110 & 07/21/03 & 231 & 8.31 & 11.0 & 76.6 & 2.29 & 114 & 143 & 229 & 405 \\
\hline VT-UHW 111 & 07/22/03 & 149 & 7.50 & 14.4 & 63.9 & 4.40 & 74 & 99 & 397 & 198 \\
\hline VT-JEW 126 & 07/22/03 & 197 & 8.34 & 11.8 & 16.6 & 4.32 & 100 & 121 & 34.0 & 147 \\
\hline VT-JEW 127 & 07/24/03 & 125 & 6.15 & 12.3 & 48.7 & 1.86 & 58 & 88 & 52.0 & 111 \\
\hline \multicolumn{11}{|c|}{ Summary statistics } \\
\hline & Minimum & 103 & 6.15 & 9.3 & 2.8 & 0.45 & 38 & 76 & 4.9 & 67 \\
\hline & Maximum & 323 & 8.34 & 14.4 & 128 & 7.83 & 138 & 173 & 397 & 405 \\
\hline & Median & 161 & 7.54 & 11 & 22 & 3.3 & 75 & 97 & 49 & 129 \\
\hline \multicolumn{11}{|c|}{ Guidelines or standards } \\
\hline & $\mathrm{MCL}^{1}$ & -- & -- & -- & -- & -- & -- & -- & -- & -- \\
\hline & $\mathrm{SMCL}^{2}$ & -- & $6.5-8.5$ & -- & -- & -- & -- & 500 & -- & -- \\
\hline
\end{tabular}

${ }^{1}$ Maximum Contaminant Level (MCL) established by the U.S. Environmental Protection Agency (2002a).

${ }^{2}$ Secondary Maximum Contaminant Level (SMCL) established by the U.S. Environmental Protection Agency (2002b). 


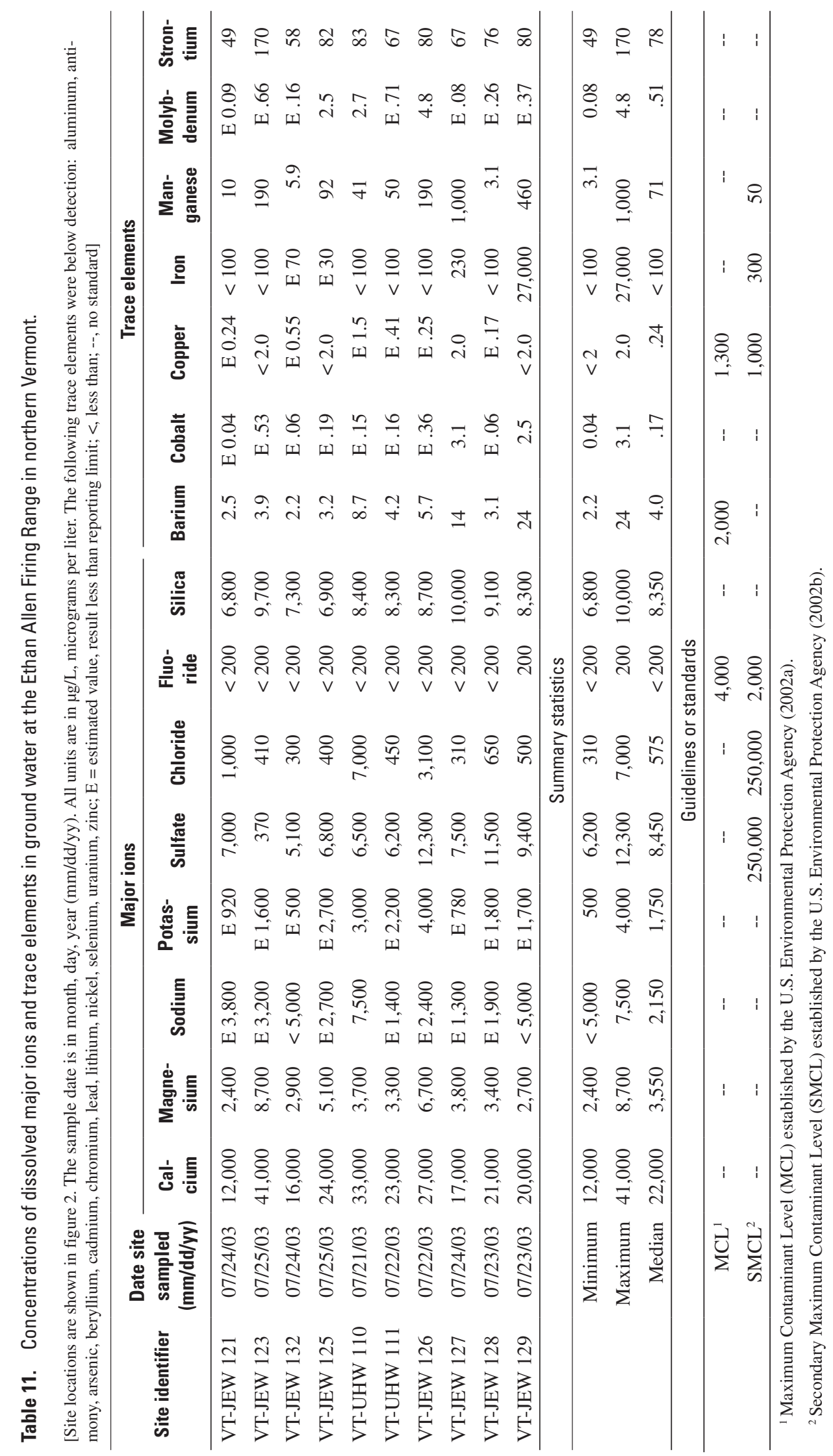




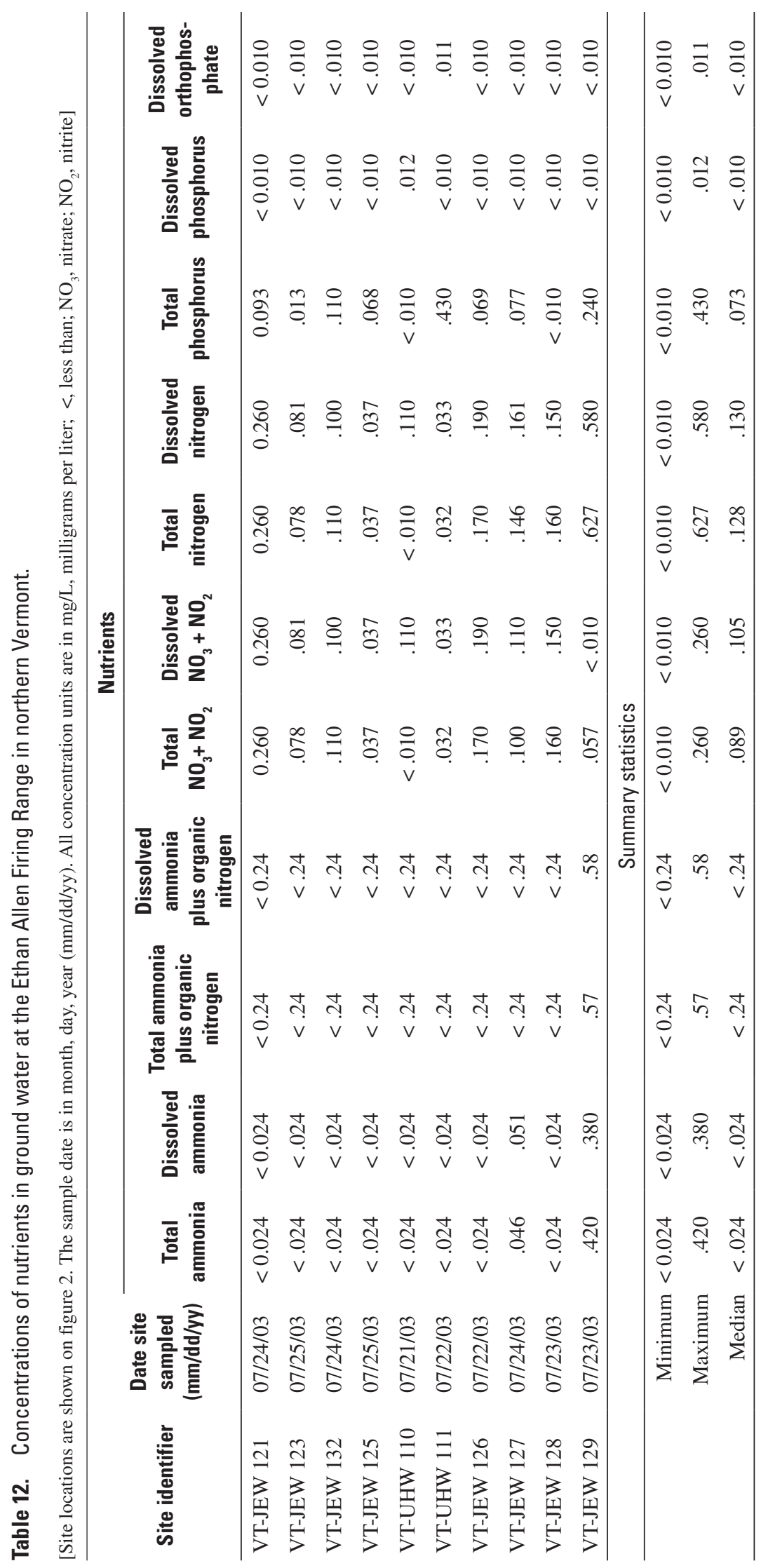




\section{Summary}

The Ethan Allan Firing Range (EAFR) in the Green Mountains of northern Vermont has been used for weapons training since 1926. The U.S. Geological Survey, in cooperation with the Vermont Army National Guard, designed and implemented a base-wide study of the hydrogeologic framework and the overall effects of military-training activities on water quality. Field activities for this study were conducted from October 2002 through December 2003.

Altitudes at the site range from about 213 to $1,122 \mathrm{~m}$ (700 to 3,680 ft) above NAVD 88, and the physiography is characterized by narrow east-west trending valleys that bisect the regional north-south trend of the Green Mountains. Most of the facility is contained within, and bounded by, the drainage that makes up the Lee River watershed. The $45.4-\mathrm{km}^{2}$ $\left(17.5 \mathrm{mi}^{2}\right)$ facility is sparsely populated, consisting of only a few offices and barracks, and supports a wide variety of wildlife. Weapons-training activities are conducted throughout the year at the facility, and historically at more than 10 firing ranges onsite. The use of explosive ammunition is limited to an Impact Area in the center of the Lee River Valley.

The headwaters of the Lee River and Mill Brook drain the west flank of the central ridge of the Green Mountains. From December 17, 2002, through December 16, 2003, streamflow in the Lee River ranged from a daily maximum flow of $10 \mathrm{~m}^{3} / \mathrm{s}\left(353 \mathrm{ft}^{3} / \mathrm{s}\right)$ on November 20, 2003, to a low flow of $0.13 \mathrm{~m}^{3} / \mathrm{s}\left(4.6 \mathrm{ft}^{3} / \mathrm{s}\right)$ on July 19 and 20, 2003, and September 15 and 19,2003. The mean streamflow was $0.72 \mathrm{~m}^{3} / \mathrm{s}\left(25 \mathrm{ft}^{3} / \mathrm{s}\right)$ and the runoff for the year was $85.8 \mathrm{~cm}$ (34 in). Comparison with streamflow in a nearby watershed with a long-term record indicates that the Lee River streamflow during the study was probably about 10 percent above normal. The Lee River watershed, on the western slopes of the Green Mountains, received less precipitation and had less annual runoff than Ranch Brook on the eastern slope of the Green Mountains for the study period.

The Lee River maintained a relatively high streamflow during dry periods (as compared to other nearby similarsized watersheds), notably July and September 2003. This comparison indicates that there is likely a large ground-water contribution to streamflow during periods of low recharge. The Lee River Valley contains a large area of relatively permeable stratified-drift deposits that act as storage for ground-water resources.

The EAFR is underlain by fine- to medium-grained micaeous metamorphic rocks consisting of low-grade granofels and phyllites. The bedrock-well yields in these rocks are generally low, typically $23 \mathrm{~L} / \mathrm{min}(6 \mathrm{gal} / \mathrm{min})$ or less, but may be greater in fracture zones or where minerals more susceptible to weathering produce more porous rock. The textural and compositional differences in the mapped bedrock units (Pinnacle and Underhill Formations) are enough to define mapable rock units, but generally do not create regional varia- tions in hydraulic properties of the bedrock aquifer underlying the EAFR.

The Lee River Valley floor is capped by a thin layer of stratified drift, consisting of well-sorted sand and gravel. Beneath this coarse cap, sand grades to poorly sorted cobble, gravel, and pebble gravel with sand. In some areas, a meter of clay locally divides the coarse cobble gravels and sands. Thick deposits, up to about $18 \mathrm{~m}(60 \mathrm{ft})$ thick of fine sand and silt, lie beneath this clay at the eastern extent of the valley floor. At the western boundary of the EAFR, the unconsolidated aquifer consists of very fine sand and silt beneath a coarse-streambed-sediment cap. The overall direction of ground-water flow in the Lee River and Mill Brook Valleys is east to west as indicated by water-table contours.

The stratified-drift deposits in the Mill Brook Valley grade from coarse pebble gravel, cobble gravel, and coarse sand on the east to clay towards the west side of the valley. The coarse deposits at ground surface in the Lee River Valley are not present in the Mill Brook Valley. Maximum thickness of stratified-drift deposits in the Mill Brook Valley is generally about $18 \mathrm{~m}$ (60 ft) but locally may be greater. Ground-water gradients and hydraulic conductivities in the Lee River Valley are greater than those in the Mill River Valley. As a result, ground-water flow in the Lee River Valley is estimated to be approximately 0.2 to $0.6 \mathrm{~m} / \mathrm{d}(0.6$ to $2 \mathrm{ft} / \mathrm{d})$, and in the Mill River Valley is estimated to be $0.2 \mathrm{~m} / \mathrm{d}(0.6 \mathrm{ft} / \mathrm{d})$ or less.

Ground-water samples were collected during July 2003, while surface-water samples were collected during moderateflow conditions in June 2003 and during low-flow conditions in July 2003. The regional surface- and ground-water quality of the base reflects the rural nature of the site and the buffering effect of the glacial deposits of the region. A high abundance and diversity of aquatic macroinvertebrates, particularly pollution-intolerant species, indicate that steams had excellent biological health. Of particular interest is the presence of native-trout populations, which are intolerant of degraded water quality.

Comparisons between surface water, streambed sediment, and biological samples collected in 2003 to earlier studies of the EAFR indicate that water-quality conditions are similar or have improved over the past 15 years. The alkalinities and $\mathrm{pH}$ of surface and ground water are moderate to relatively high compared to other areas of New England. Sampling results indicate that overall water-quality conditions at the facility meet State and Federal guidelines. Concentrations of trace elements (except for iron in ground water from one well) and nutrients in surface water were below freshwater-quality guidelines for the protection of aquatic or human life at all sites. Concentrations of trace elements in streambed sediments and fish tissue were also well below guidelines for the probable adverse effects to aquatic or human health. Concentrations of Escherichia-coli in surface water were below swimming guidelines at all sites, but above detection levels at most surface sites during low-flow conditions, indicating surface water at the facility should not be used for drinking unless it is first treated. The buffered effect of the glacial sediments at 
the EAFR likely contributes to the low occurrence of trace elements in surface and ground water. Volatile organic compounds and semivolatile organic compounds were not detected in any water samples.

\section{Selected References}

Bird, J.M., and Dewey, J.F., 1970, Lithosphere plate-continental margin tectonics and the evolution of the Appalachian Orogen: Geological Survey of America Bulletin, v. 81, p. 1031-1060.

Bonds, J.D., Sherwood, J.K., Civitarese, K.A., 1987, Update of the initial installation assessment of Ethan Allen Firing Range, AMXTH-IR-A-158 (U), Vermont: Gainesville, Fla., Environmental Science and Engineering, Inc., 20 p.

Bouwkamp, C.A., 1992, Effects of munitions on water quality of the Ethan Allen Firing Range, Vermont, 21-25 September, 2 October and 10 November 1992: Department of the Army, U.S. Army Environmental Hygiene Agency Receiving water biological study no. 32-24-HK78-93, 9 p.

Brady, Nyle, C., 1974, The nature and properties of soils: New York, Macmillan Publishing Co., Inc., p. 54.

Buchannan, T.J., and Somers, W.P., 1969, Discharge measurements at gaging stations: U.S. Geological Survey Techniques of Water-Resources Investigations, book 3, chap. A8, $65 \mathrm{p}$.

Butoryak, K.R., 1995, Site investigation no. 38-26-3268-95, Ethan Allen Firing Range, Jericho, Vt.: Department of the Army Center for Health Promotion and Preventive Medicine, $15 \mathrm{p}$.

Butoryak, K.R., 1996, Phase II ground-water sampling for site investigation no. 38-EH-3268-96, Ethan Allen Firing Range, Jericho, Vt.: Department of the Army Center for Health Promotion and Preventive Medicine, $7 \mathrm{p}$.

Cady, W.M., 1956, Bedrock geology of the Montpelier quadrangle, Vermont: U.S. Geological Survey Geologic Quadrangle Map GQ 79, 1:62,500-scale.

Canadian Council of Ministers of the Environment, 2003, Canadian streambed sediment quality guidelines for the protection of aquatic life, in Canadian environmental quality guidelines: Winnipeg, Canada, Summary tables, accessed December 1, 2004, at http://www.ccme.ca/assets/pdf/ e1_062.pdf

Christman, R.A., and Secor, D.T., Jr., 1961, Geology of the Camels Hump quadrangle, Vermont: Vermont Geological Survey, Bulletin no. 15, 70 p.
Clapp, Erick, and Bierman, Paul, 1994, Assessment of potential groundwater resources in the town of Jericho, Vermont, Fall 1994: Burlington, Vt., University of Vermont, Masters Thesis, $17 \mathrm{p}$.

Clark, S.F., Jr., Moore, R.B., Ferguson, E.W., and Picard, M.Z., 1996, Criteria and methods for fracture-trace analysis of the New Hampshire bedrock aquifer: U.S. Geological Survey Open-File Report 96-479, 12 p.

Crawford, J.K., and Luoma, S.N., 1993, Guidelines for studies of contaminants in biological tissues for the National WaterQuality Assessment program: U.S. Geological Survey Open-File Report 92-494, 69 p.

Cuffney, T.F., Gurtz, M.E., and Meador, M.R., 1993, Methods for collecting benthic invertebrate samples as part of the National Water-Quality Assessment program: U.S. Geological Survey Open-File Report 93-406, 66 p.

Deere, D.U., and Deere, D.W., 1988, The rock quality designation (RQD) index in L. Kirkaldie, ed., Practice, rock classification systems for engineering purposes: Philadelphia, American Society of Testing Materials, Special Publication 984, p. 91-101.

Freeze, R.A., and Cherry, J.A., 1979, Groundwater: Englewood Cliffs, N.J., Prentice-Hall, 604 p.

Goetz, L.A., 1999, Effects of munitions on water quality at Ethan Allen Firing Range: Vermont National Guard, Memorandum for record, $7 \mathrm{p}$.

Hilsenhoff, W.L., 1987, An improved biotic index of organic stream pollution: The Great Lakes Entomologist, v. 20, no. 1 , p. 31-39.

Keirstead, Chandlee, Kiah, R.G., Brown, R.O., and Ward, S.A., 2004, Water resources data, New Hampshire and Vermont, water year 2003: U.S. Geological Survey Water-Data Report NH-VT-03-1, 323 p.

Ladue, W.H., 1982, The glacial history and environmental history of Jericho, Vermont: Burlington, Vt., University of Vermont, Masters Thesis, 176 p.

Larsen, F.D., 1999, Glacial history of the Montpelier, Vermont, 7.5 minute quadrangle, in Wright, S.F., ed., New England Intercollegiate Geologic Conference Guidebook: no. 91, p. 286-300.

MacDonald, D.D., Ingersoll, C.G., Bergan, T.A., 2000, Development and evaluation of censenses-based streambed sediment-quality guidelines for freshwater ecosystems: Archive of Environmental Contamination and Toxicology, v. 39, p. 20-31. 
Mack, T.J., 1995, Hydrogeology, simulated ground-water flow, and ground-water quality at two landfills in Bristol, Vermont: U.S. Geological Survey Water-Resources Investigations Report 94-4108, 120 p.

Mack, T.J., 2003, Preliminary ground-water-flow model of a coastal bedrock-aquifer system, southeastern New Hampshire, in MODFLOW and More 2003: Understanding through modeling, September 17-19, 2003, Abstracts with Programs: International Ground Water Modeling Center, Denver, Colo.

Mallard, L.D., 2000, Stratigraphic structural, and fault history analyses of the Richmond 7.5-minute quadrangle, northcentral Vermont: Burlington, Vt., University of Vermont, Masters Thesis, 157 p., 4 maps (bedrock geology within Ethan Allen Firing Range).

Meador, M.R., Cuffney, T.F., and Gurtz, M.E., 1993, Methods for sampling fish communities as part of the National Water-Quality Assessment program: U.S. Geological Survey Open-File Report 93-104, 40 p.

Melvin, R.L., DeLima, Virginia, and Stone, B.D., 1992, The stratigraphy and hydraulic properties of tills in southern New England: U.S. Geological Survey Open-File Report 91-148, p. 53.

Moore, R.B., Schwarz, G.E., Clark, S.F., Jr., Walsh, G.J., and Degnan, J.R., 2002, Factors related to well yield in the fractured-bedrock aquifer of New Hampshire: U.S. Geological Survey Professional Paper 1660, 51 p., 2 pls.

Mullen, J.C., 1971, Environmental geology of Milton, Westford, and Underhill, Vermont: Burlington, Vt., University of Vermont, Masters Thesis, 76 p.

Rantz, S.E. and others, 1982, Measurement and computation of streamflow: Volume 1., Measurement of stage and discharge and Volume 2 Computation of discharge: U.S. Geological Survey Water-Supply Paper 2175, 1-284 p.

Risch, M.R., 2004, Chemical and biological quality of surface water at the U.S. Army Atterbury Reserve Forces Training Area near Edinburgh, Indiana, September 2000 through July 2001: U.S. Geological Survey Water-Resources Investigations Report 03-4149, 87 p.

Robert B. Balter Co., 1979, Assessment of contaminant migration, Ethan Allen Firing Range, Chittenden County, Vermont: Owings Mills, Md., 12 p.

Robinson, G.R., and Kapo, K.E., 2003, Generalized lithology and lithogeochemical character of near-surface bedrock in the New England Region: U.S. Geological Survey Open-File Report 03-225, 60 p., available only at http://pubs.er.usgs.gov/pubs/ofr/ofr03225
Rowley, D.B., and Kidd, W.S., 1981, Stratigraphic relationships and detridal composition of Medial Ordovician flysch of western New England: Implications for the tectonic evolution of the Taconic Orogeny: Journal of Geology. v. 89, p. 199-218.

Shelton, L.R., 1994, Field guide for collecting and processing stream-water samples for the National Water-Quality Assessment Program: U.S. Geological Survey Open-File Report 94-455, 42 p.

Shelton, L.R., and Capel, P.D., 1994, Guidelines for collecting and processing samples of stream bed streambed sediment for analysis of trace elements and organic contaminants for the National Water-Quality Assessment Program: U.S. Geological Survey Open-File Report 94-458, 20 p.

Stanley, R.S., and Ratcliffe, N.M., 1985, Tectonic synthesis of the Taconian Orogeny in western New England: Geological Society of America Bulletin, v. 96, p. 1227-1250.

Stanley, R.S., Thompson, P.J., Gale, M., and Walsh, G.J., 2002, Geologic map of the Montpelier quadrangle, Vermont: Vermont Geological Survey, 1:100,000 scale, 1 sheet.

Stewart, D.P., and MacClintock, 1969, The surficial geology and Pleistocene history of Vermont: Vermont Geological Survey, Special Bulletin no. 13, 251 p.

Stewart, D.P., 1973, Geology for environmental planning in the Burlington-Middlebury region, Vermont: Vermont Geological Survey, Water Resources Department, Environmental Geology, no. 3, 45 p.

St. Julien, P., and Hubert, C., 1975, Evolution of the Taconic Orogen in the Quebec Appalachians: American Journal of Science, v. 275-A, p. 337-362.

Thompson, P.J., and Thompson, T.B., 1992, Bedrock geology of the Camels Hump-Bolton Mountain area north-central Vermont: Vermont Geological Survey, Special Bulletin no. $12,32 \mathrm{p}$.

Thompson, P.J., and Thompson, T.B., 1997, Bedrock geology of the Mt. Mansfield, Jeffersonville, and Bolton Mountain quadrangles, Vermont: Vermont Geological Survey, 1 sheet.

Tiedeman, C.R., Goode, D.J., and Hsieh, P.A., 1998, Characterizing a ground-water basin in a New England mountain and valley terrain: Ground Water, v. 36, no. 4, p. 611-620.

Ward, Mark, 1999, A survey of aquatic marcroinvertebrates in streams and vernal pools at Ethan Allen Firing Range, Jericho, Vermont: 21 p.

Wilde, F.D., Radtke, D.B., Gibs, J., and Iwatsubo, R.T., eds., 1998, National field manual for the collection of waterquality data: U.S. Geological Survey Techniques of WaterResources Investigations, book 9, chap. A1, 47 p. 
U.S. Army, 1980, Installation assessment of Ethan Allen Firing Range: Aberdeen Proving Ground, Maryland: U.S. Army Toxic and Hazardous Materials Agency, Report no. 158, $40 \mathrm{p}$.

U.S. Environmental Protection Agency, 1983, Methods for chemical analysis of water and wastes: Environmental Monitoring and Support Laboratory, Report no. EPA-600/ 4-79-020, variously paged.

U.S. Environmental Protection Agency, 1995, 2nd ed., Guidance for assessing chemical contaminant data for use in fish advisories, Fish sampling and analysis: Washington, D.C., Office of Water, EPA 823-R-95-007, v. 1, variously paged.

U.S. Environmental Protection Agency, 2002a, Maximum contaminant level for drinking water, accessed December 1, 2004, at http://www.epa.gov/safewater/mcl.html\#mc
U.S. Environmental Protection Agency, 2002b, Secondary maximum contaminant level for drinking water, accessed December 1, 2004, at http://www.epa.gov/safewater/mcl. html\#sec

U.S. Environmental Protection Agency, 1995, Guidance for assessing chemical contaminant data for use in fish advisories, v. 1, Fish sampling and analysis, 2nd ed.: Washington, D.C., U.S. Environmental Protection Agency, Office of Water, EPA 823-R-95-007, variously paginated.

U.S. Food and Drug Administration, 1993, Guidance documents for selected elements (arsenic, cadmium, lead, nickel) in shellfish: Washington, D.C., Center for Food Safety and Applied Nutrition, accessed March 18, 2004, at http://www. cfsan.fda.gov/ frf/guid-sf.htm

Vermont Water Resources Board, 2004, Guidelines for Escherichia coli bacteria, accessed January 15, 2004, at http://www.uvm.edu/ empact/water/ques5.php3 



\section{Appendixes 1-4}


Appendix 1. Lithologic logs of wells and boring drilled at the Ethan Allen Firing Range in northern Vermont.

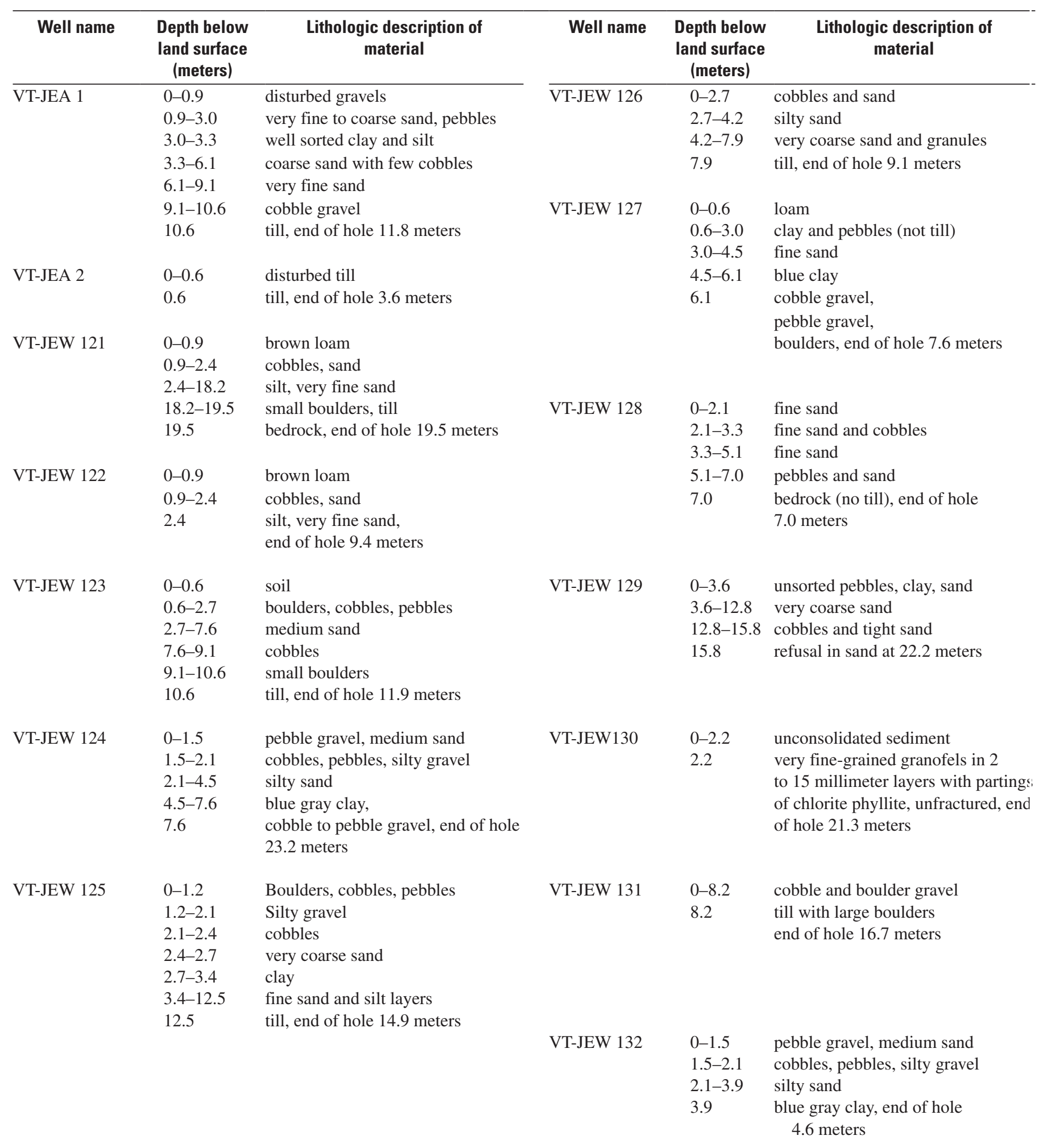


Appendix 1. Lithologic logs of wells and boring drilled at the Ethan Allen Firing Range in northern Vermont.-Continued

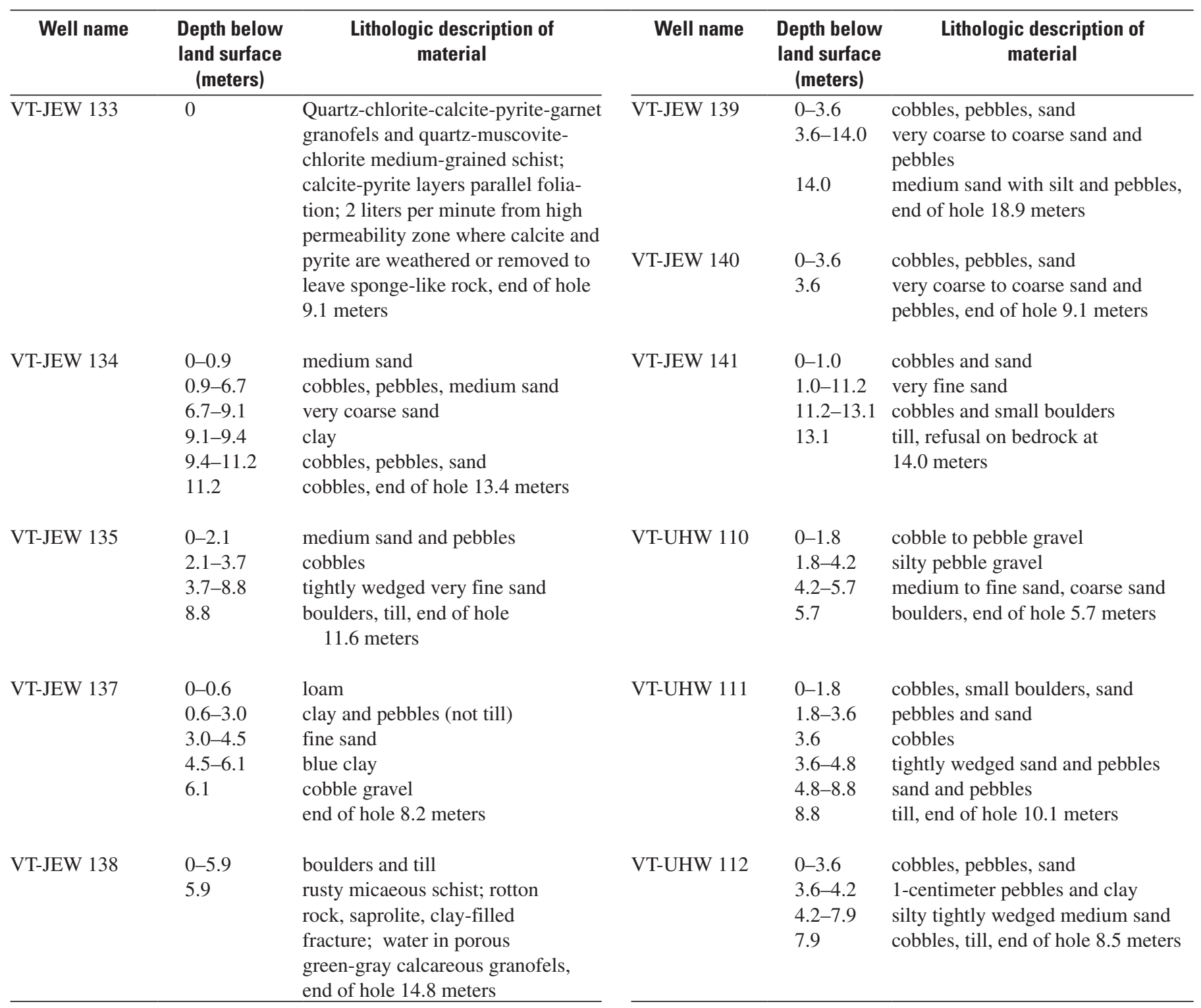


Appendix 2. Well data in and near the Ethan Allen Firing Range in northern Vermont. Data from the Vermont Agency of Natural Resources.

[Well locations shown in figure 2. m, meters; L/min, liter/minute; --, no data]

\begin{tabular}{|c|c|c|c|c|c|c|c|c|c|c|c|}
\hline \multirow{2}{*}{$\begin{array}{c}\text { Well } \\
\text { number } \\
\text { (m) }\end{array}$} & \multirow{2}{*}{$\begin{array}{l}\text { Well depth } \\
\text { (m) }\end{array}$} & \multirow{2}{*}{$\begin{array}{l}\text { Yield } \\
\text { (L/min) }\end{array}$} & \multirow{2}{*}{$\begin{array}{l}\text { Depth to } \\
\text { water } \\
\text { (m) }\end{array}$} & \multirow{2}{*}{$\begin{array}{l}\text { Overburden } \\
\text { thickness } \\
\text { (m) }\end{array}$} & \multirow{2}{*}{$\begin{array}{c}\text { Casing } \\
\text { length } \\
\text { (m) }\end{array}$} & \multicolumn{3}{|c|}{ Latitude } & \multicolumn{3}{|c|}{ Longitude } \\
\hline & & & & & & Degrees & Minutes & Seconds & Degrees & Minutes & Seconds \\
\hline BO11 & 72.3 & 170 & -- & -- & 19.2 & 44 & 26 & 45 & 72 & 53 & 43 \\
\hline BO16 & 60.4 & 30 & -- & -- & 21.0 & 44 & 26 & 41 & 72 & 53 & 51 \\
\hline BO28 & 53.0 & 23 & -- & -- & 24.4 & 44 & 26 & 40 & 72 & 53 & 50 \\
\hline BO15816 & 42.7 & 114 & -- & 18.9 & 20.9 & 44 & 26 & 38 & 72 & 53 & 40 \\
\hline BO17524 & 83.8 & 95 & -- & 12.8 & 17.1 & 44 & 26 & 40 & 72 & 54 & 22 \\
\hline JE1 & 47.9 & 227 & 1.5 & 18.3 & 18.3 & 44 & 28 & 51 & 72 & 56 & 46 \\
\hline JE8 & 91.5 & 114 & -- & -- & 11.0 & 44 & 26 & 50 & 72 & 55 & 29 \\
\hline JE10 & 60.4 & 19 & -- & -- & 8.2 & 44 & 26 & 49 & 72 & 56 & 22 \\
\hline JE43 & 44.2 & 19 & -- & -- & 20.4 & 44 & 28 & 22 & 72 & 57 & 29 \\
\hline JE67 & 38.1 & 114 & -- & -- & 9.1 & 44 & 26 & 50 & 72 & 56 & 34 \\
\hline JE94 & 121.3 & 19 & -- & -- & 14.0 & 44 & 29 & 5 & 72 & 57 & 41 \\
\hline JE95 & 121.0 & 30 & -- & -- & 9.8 & 44 & 29 & 2 & 72 & 57 & 42 \\
\hline JE111 & 74.1 & 57 & -- & -- & 32.3 & 44 & 26 & 39 & 72 & 54 & 56 \\
\hline JE124 & 68.0 & 4 & -- & -- & 26.2 & 44 & 27 & 2 & 72 & 54 & 52 \\
\hline JE12913 & 182.9 & 9 & -- & 19.2 & 25.0 & 44 & 28 & 11 & 72 & 57 & 29 \\
\hline JE14374 & 92.4 & 19 & -- & 31.4 & 32.3 & 44 & 27 & 3 & 72 & 56 & 16 \\
\hline JE17522 & 106.7 & 38 & -- & 10.7 & 30.5 & 44 & 28 & 32 & 72 & 57 & 42 \\
\hline JE17523 & 236.3 & 19 & -- & 49.4 & 54.9 & 44 & 28 & 13 & 72 & 57 & 23 \\
\hline JE17525 & 129.6 & 227 & -- & 11.9 & 15.2 & 44 & 26 & 56 & 72 & 54 & 23 \\
\hline JE18303 & 76.2 & 34 & -- & 5.2 & 24.4 & 44 & 26 & 43 & 72 & 54 & 43 \\
\hline JE18356 & 77.7 & 76 & -- & 13.7 & 30.5 & 44 & 26 & 51 & 72 & 56 & 15 \\
\hline JE26778 & 97.9 & 11 & 1.5 & 22.3 & -- & 44 & 28 & 42 & 72 & 56 & 16 \\
\hline UH12773 & 99.1 & 17 & .0 & 1.5 & 18.3 & 44 & 30 & 0 & 72 & 54 & 23 \\
\hline UH12921 & 68.6 & 57 & .0 & 4.0 & 18.3 & 44 & 29 & 55 & 72 & 54 & 20 \\
\hline
\end{tabular}


Appendix 3. Constituents analyzed and reporting limits for analysis of water, streambed sediment, and fish tissue at the Ethan Allen Firing Range in northern Vermont.

[Constituent reporting levels for analysis of water (surface and ground) and solids (streambed sediment and fish tissue) collected at the Ethan Allen Firing Range. All constituents were analyzed in surface- and ground-water samples. Major ions and trace elements were analyzed in streambed sediment and fish-tissue samples. Units are in mg/L, milligrams per liter; NTU, nephelometric turbitiy units; $\mu \mathrm{g} / \mathrm{L}$, micrograms per liter; $\mathrm{mg} / \mathrm{kg}$, milligrams per kilogram]

\begin{tabular}{|c|c|c|c|}
\hline Constituent & Media & Reporting limit & Units \\
\hline \multicolumn{4}{|c|}{ Characteristics, nutrients, major ions } \\
\hline Total dissolved solids & Water & 5 & $\mathrm{mg} / \mathrm{L}$ \\
\hline Total suspended solids & Water & .5 & $\mathrm{mg} / \mathrm{L}$ \\
\hline Total solids & Water & 5 & $\mathrm{mg} / \mathrm{L}$ \\
\hline Turbidity (NTU) & Water & .05 & NTU \\
\hline Chloride dissolved & Water & .2 & $\mathrm{mg} / \mathrm{L}$ \\
\hline Fluoride dissolved & Water & .2 & $\mathrm{mg} / \mathrm{L}$ \\
\hline Sulfate dissolved & Water & .2 & $\mathrm{mg} / \mathrm{L}$ \\
\hline Calcium & Solids & 20 & $\mathrm{mg} / \mathrm{kg}$ \\
\hline Calcium & Water & 200 & $\mu \mathrm{g} / \mathrm{L}$ \\
\hline Magnesium & Solids & 20 & $\mathrm{mg} / \mathrm{kg}$ \\
\hline Magnesium & Water & 200 & $\mu \mathrm{g} / \mathrm{L}$ \\
\hline Potassium & Solids & 300 & $\mathrm{mg} / \mathrm{kg}$ \\
\hline Potassium & Water & 3,000 & $\mu \mathrm{g} / \mathrm{L}$ \\
\hline Silica & Water & 1,100 & $\mu \mathrm{g} / \mathrm{L}$ \\
\hline Sodium & Solids & 500 & $\mathrm{mg} / \mathrm{kg}$ \\
\hline Sodium & Water & 5,000 & $\mu \mathrm{g} / \mathrm{L}$ \\
\hline Hydroxide alkalinity & Water & 1 & $\mathrm{mg} / \mathrm{L}$ \\
\hline Carbonate alkalinity & Water & 1 & $\mathrm{mg} / \mathrm{L}$ \\
\hline Bicarbonate alkalinity & Water & 1 & $\mathrm{mg} / \mathrm{L}$ \\
\hline Total alkalinity & Water & 1 & $\mathrm{mg} / \mathrm{L}$ \\
\hline Ammonia-Nitrogen dissolved & Water & .024 & $\mathrm{mg} / \mathrm{L}$ \\
\hline Ammonia-Nitrogen total & Water & .024 & $\mathrm{mg} / \mathrm{L}$ \\
\hline Ammonia plus organic nitrogen, dissolved & Water & .24 & $\mathrm{mg} / \mathrm{L}$ \\
\hline Ammonia plus organic nitrogen, total & Water & .24 & $\mathrm{mg} / \mathrm{L}$ \\
\hline $\mathrm{NO}_{3}+\mathrm{NO}_{2}$ Nitrogen dissolved & Water & .01 & $\mathrm{mg} / \mathrm{L}$ \\
\hline $\mathrm{NO}_{3}+\mathrm{NO}_{2}$ Nitrogen total & Water & .01 & $\mathrm{mg} / \mathrm{L}$ \\
\hline Orthophosphate as $\mathrm{P}$ dissolved & Water & .01 & $\mathrm{mg} / \mathrm{L}$ \\
\hline Phosphorus as P dissolved & Water & .01 & $\mathrm{mg} / \mathrm{L}$ \\
\hline Phosphorus as P total & Water & .01 & $\mathrm{mg} / \mathrm{L}$ \\
\hline \multicolumn{4}{|c|}{ Trace elements } \\
\hline Aluminum & Solids & 10 & $\mathrm{mg} / \mathrm{kg}$ \\
\hline Aluminum & Water & 100 & $\mu \mathrm{g} / \mathrm{L}$ \\
\hline Antimony & Solids & 200 & $\mu \mathrm{g} / \mathrm{kg}$ \\
\hline Antimony & Water & 2 & $\mu \mathrm{g} / \mathrm{L}$ \\
\hline Arsenic & Solids & 500 & $\mu \mathrm{g} / \mathrm{kg}$ \\
\hline Arsenic & Water & 5 & $\mu \mathrm{g} / \mathrm{L}$ \\
\hline Barium & Solids & 1 & $\mathrm{mg} / \mathrm{kg}$ \\
\hline Barium & Water & 1 & $\mu \mathrm{g} / \mathrm{L}$ \\
\hline Beryllium & Solids & 0.5 & $\mathrm{mg} / \mathrm{kg}$ \\
\hline Beryllium & Water & 5 & $\mu \mathrm{g} / \mathrm{L}$ \\
\hline Cadmium & Solids & 100 & $\mu \mathrm{g} / \mathrm{kg}$ \\
\hline
\end{tabular}


Appendix 3. Constituents analyzed and reporting limits for analysis of water, streambed sediment, and fish tissue at the Ethan Allen Firing Range in northern Vermont.-Continued

[Constituent reporting levels for analysis of water (surface and ground) and solids (streambed sediment and fish tissue) collected at Ethan Allen Firing Range. All constituents were analyzed in surface- and ground-water samples. Major ions and trace elements were analyzed in streambed sediment and fish-tissue samples. Units are in mg/L, milligrams per liter; NTU, nephelometric turbitiy units; $\mu \mathrm{g} / \mathrm{L}$, micrograms per liter; mg/kg, milligrams per kilogram]

\begin{tabular}{|c|c|c|c|}
\hline Constituent & Media & Reporting limit & Units \\
\hline \multicolumn{4}{|c|}{ Trace elements--Continued } \\
\hline Cadmium & Water & 1 & $\mu \mathrm{g} / \mathrm{L}$ \\
\hline Chromium & Solids & 200 & $\mathrm{ug} / \mathrm{kg}$ \\
\hline Chromium & Water & 2 & $\mu \mathrm{g} / \mathrm{L}$ \\
\hline Cobalt & Solids & 100 & $\mathrm{ug} / \mathrm{kg}$ \\
\hline Cobalt & Water & 1 & $\mu \mathrm{g} / \mathrm{L}$ \\
\hline Copper & Solids & 200 & $\mathrm{ug} / \mathrm{kg}$ \\
\hline Copper & Water & 2 & $\mu \mathrm{g} / \mathrm{L}$ \\
\hline Iron & Solids & 10 & $\mathrm{mg} / \mathrm{kg}$ \\
\hline Iron & Water & 100 & $\mu \mathrm{g} / \mathrm{L}$ \\
\hline Lead & Solids & 100 & $\mathrm{ug} / \mathrm{kg}$ \\
\hline Lead & Water & 1 & $\mu \mathrm{g} / \mathrm{L}$ \\
\hline Lithium & Solids & 5 & $\mathrm{mg} / \mathrm{kg}$ \\
\hline Lithium & Water & 10 & $\mu \mathrm{g} / \mathrm{L}$ \\
\hline Manganese & Solids & 1 & $\mathrm{mg} / \mathrm{kg}$ \\
\hline Manganese & Water & 1 & $\mu \mathrm{g} / \mathrm{L}$ \\
\hline Molybdenum & Solids & 2 & $\mathrm{mg} / \mathrm{kg}$ \\
\hline Molybdenum & Water & 2 & $\mu \mathrm{g} / \mathrm{L}$ \\
\hline Nickel & Solids & 100 & $\mathrm{ug} / \mathrm{kg}$ \\
\hline Nickel & Water & 2 & $\mu \mathrm{g} / \mathrm{L}$ \\
\hline Selenium & Solids & 500 & $\mathrm{ug} / \mathrm{kg}$ \\
\hline Selenium & Water & 5 & $\mu \mathrm{g} / \mathrm{L}$ \\
\hline Strontium & Solids & 1 & $\mathrm{mg} / \mathrm{kg}$ \\
\hline Strontium & Water & 10 & $\mu \mathrm{g} / \mathrm{L}$ \\
\hline Uranium & Solids & 100 & $\mathrm{ug} / \mathrm{kg}$ \\
\hline Uranium & Water & 1 & $\mu \mathrm{g} / \mathrm{L}$ \\
\hline Zinc & Solids & 1,000 & $\mathrm{ug} / \mathrm{kg}$ \\
\hline Zinc & Water & 10 & $\mu \mathrm{g} / \mathrm{L}$ \\
\hline \multicolumn{4}{|c|}{ Volatile organic compounds } \\
\hline Ethylbenzene & Water & 1 & $\mu \mathrm{g} / \mathrm{L}$ \\
\hline Styrene & Water & 1 & $\mu \mathrm{g} / \mathrm{L}$ \\
\hline cis-1,3-Dichloropropene & Water & 1 & $\mu \mathrm{g} / \mathrm{L}$ \\
\hline trans-1,3-Dichloropropene & Water & 1 & $\mu \mathrm{g} / \mathrm{L}$ \\
\hline n-Propylbenzene & Water & 1 & $\mu \mathrm{g} / \mathrm{L}$ \\
\hline n-Butylbenzene & Water & 1 & $\mu \mathrm{g} / \mathrm{L}$ \\
\hline 4-Chlorotoluene & Water & 1 & $\mu \mathrm{g} / \mathrm{L}$ \\
\hline 1,4-Dichlorobenzene & Water & 1 & $\mu \mathrm{g} / \mathrm{L}$ \\
\hline 1,2-Dibromoethane & Water & 1 & $\mu \mathrm{g} / \mathrm{L}$ \\
\hline Acrolein & Water & 5 & $\mu \mathrm{g} / \mathrm{L}$ \\
\hline Allyl Chloride & Water & 1 & $\mu \mathrm{g} / \mathrm{L}$ \\
\hline 1,2-Dichloroethane & Water & 1 & $\mu \mathrm{g} / \mathrm{L}$ \\
\hline Propionitrile & Water & 4 & $\mu \mathrm{g} / \mathrm{L}$ \\
\hline Acrylonitrile & Water & 1 & $\mu \mathrm{g} / \mathrm{L}$ \\
\hline Vinyl Acetate & Water & 1 & $\mu \mathrm{g} / \mathrm{L}$ \\
\hline 4-Methyl-2-pentanone & Water & 5 & $\mu \mathrm{g} / \mathrm{L}$ \\
\hline $1,3,5$-Trimethylbenzene & Water & 1 & $\mu \mathrm{g} / \mathrm{L}$ \\
\hline
\end{tabular}


Appendix 3. Constituents analyzed and reporting limits for analysis of water, streambed sediment, and fish tissue at the Ethan Allen Firing Range in northern Vermont.-Continued

[Constituent reporting levels for analysis of water (surface and ground) and solids (streambed sediment and fish tissue) collected at Ethan Allen Firing Range. All constituents were analyzed in surface- and ground-water samples. Major ions and trace elements were analyzed in streambed sediment and fish-tissue samples. Units are in mg/L, milligrams per liter; NTU, nephelometric turbitiy units; $\mu \mathrm{g} / \mathrm{L}$, micrograms per liter; $\mathrm{mg} / \mathrm{kg}$, milligrams per kilogram]

\begin{tabular}{|c|c|c|c|}
\hline Constituent & Media & Reporting limit & Units \\
\hline \multicolumn{4}{|c|}{ Volatile organic compounds--Continued } \\
\hline Bromobenzene & Water & 1 & $\mu \mathrm{g} / \mathrm{L}$ \\
\hline Toluene & Water & 1 & $\mu \mathrm{g} / \mathrm{L}$ \\
\hline Chlorobenzene & Water & 1 & $\mu \mathrm{g} / \mathrm{L}$ \\
\hline Tetrahydrofuran & Water & 14 & $\mu \mathrm{g} / \mathrm{L}$ \\
\hline trans-1,4-Dichloro-2-butene & Water & 1 & $\mu \mathrm{g} / \mathrm{L}$ \\
\hline 2-Chloroethyl Vinyl Ether & Water & 1 & $\mu \mathrm{g} / \mathrm{L}$ \\
\hline 1,2,4-Trichlorobenzene & Water & 1 & $\mu \mathrm{g} / \mathrm{L}$ \\
\hline 1,4-Dioxane & Water & 50 & $\mu \mathrm{g} / \mathrm{L}$ \\
\hline Dibromochloromethane & Water & 1 & $\mu \mathrm{g} / \mathrm{L}$ \\
\hline Methacrylonitrile & Water & 1 & $\mu \mathrm{g} / \mathrm{L}$ \\
\hline Chloroprene & Water & 1 & $\mu \mathrm{g} / \mathrm{L}$ \\
\hline Tetrachloroethene & Water & 1 & $\mu \mathrm{g} / \mathrm{L}$ \\
\hline Xylene (m,p) & Water & 1 & $\mu \mathrm{g} / \mathrm{L}$ \\
\hline Xylene (total) & Water & 1 & $\mu \mathrm{g} / \mathrm{L}$ \\
\hline sec-Butylbenzene & Water & 1 & $\mu \mathrm{g} / \mathrm{L}$ \\
\hline 1,3-Dichloropropane & Water & 1 & $\mu \mathrm{g} / \mathrm{L}$ \\
\hline cis-1,4-Dichloro-2-butene & Water & 1 & $\mu \mathrm{g} / \mathrm{L}$ \\
\hline cis-1,2-Dichloroethene & Water & 1 & $\mu \mathrm{g} / \mathrm{L}$ \\
\hline trans-1,2-Dichloroethene & Water & 1 & $\mu \mathrm{g} / \mathrm{L}$ \\
\hline Methyl-t-Butyl Ether & Water & 1 & $\mu \mathrm{g} / \mathrm{L}$ \\
\hline 1,2-Dichloroethene (total) & Water & 1 & $\mu \mathrm{g} / \mathrm{L}$ \\
\hline 1,3-Dichlorobenzene & Water & 1 & $\mu \mathrm{g} / \mathrm{L}$ \\
\hline Carbon Tetrachloride & Water & 1 & $\mu \mathrm{g} / \mathrm{L}$ \\
\hline 1,1-Dichloropropene & Water & 1 & $\mu \mathrm{g} / \mathrm{L}$ \\
\hline 2-Hexanone & Water & 5 & $\mu \mathrm{g} / \mathrm{L}$ \\
\hline 2,2-Dichloropropane & Water & 1 & $\mu \mathrm{g} / \mathrm{L}$ \\
\hline 1,1,1,2-Tetrachloroethane & Water & 1 & $\mu \mathrm{g} / \mathrm{L}$ \\
\hline Acetone & Water & 5 & $\mu \mathrm{g} / \mathrm{L}$ \\
\hline Chloroform & Water & 1 & $\mu \mathrm{g} / \mathrm{L}$ \\
\hline Benzene & Water & 1 & $\mu \mathrm{g} / \mathrm{L}$ \\
\hline 1,1,1-Trichloroethane & Water & 1 & $\mu \mathrm{g} / \mathrm{L}$ \\
\hline Bromomethane & Water & 1 & $\mu \mathrm{g} / \mathrm{L}$ \\
\hline Chloromethane & Water & 1 & $\mu \mathrm{g} / \mathrm{L}$ \\
\hline Methyl Iodide & Water & 1 & $\mu \mathrm{g} / \mathrm{L}$ \\
\hline Dibromomethane & Water & 1 & $\mu \mathrm{g} / \mathrm{L}$ \\
\hline Bromochloromethane & Water & 1 & $\mu \mathrm{g} / \mathrm{L}$ \\
\hline Chloroethane & Water & 1 & $\mu \mathrm{g} / \mathrm{L}$ \\
\hline Vinyl Chloride & Water & 1 & $\mu \mathrm{g} / \mathrm{L}$ \\
\hline Methylene Chloride & Water & 1 & $\mu \mathrm{g} / \mathrm{L}$ \\
\hline Carbon Disulfide & Water & 1 & $\mu \mathrm{g} / \mathrm{L}$ \\
\hline Bromoform & Water & 1 & $\mu \mathrm{g} / \mathrm{L}$ \\
\hline Bromodichloromethane & Water & 1 & $\mu \mathrm{g} / \mathrm{L}$ \\
\hline 1,1-Dichloroethane & Water & 1 & $\mu \mathrm{g} / \mathrm{L}$ \\
\hline 1,1-Dichloroethene & Water & 1 & $\mu \mathrm{g} / \mathrm{L}$ \\
\hline
\end{tabular}


Appendix 3. Constituents analyzed and reporting limits for analysis of water, streambed sediment, and fish tissue at the Ethan Allen Firing Range in northern Vermont.-Continued

[Constituent reporting levels for analysis of water (surface and ground) and solids (streambed sediment and fish tissue) collected at Ethan Allen Firing Range. All constituents were analyzed in surface- and ground-water samples. Major ions and trace elements were analyzed in streambed sediment and fish-tissue samples. Units are in mg/L, milligrams per liter; NTU, nephelometric turbitiy units; $\mu \mathrm{g} / \mathrm{L}$, micrograms per liter; $\mathrm{mg} / \mathrm{kg}$, milligrams per kilogram]

\begin{tabular}{|c|c|c|c|}
\hline Constituent & Media & Reporting limit & Units \\
\hline \multicolumn{4}{|c|}{ Volatile organic compounds--Continued } \\
\hline Trichlorofluoromethane & Water & 1 & $\mu \mathrm{g} / \mathrm{L}$ \\
\hline Dichlorodifluoromethane & Water & 1 & $\mu \mathrm{g} / \mathrm{L}$ \\
\hline Freon $\mathrm{TF}$ & Water & 1 & $\mu \mathrm{g} / \mathrm{L}$ \\
\hline Isobutyl Alcohol & Water & 50 & $\mu \mathrm{g} / \mathrm{L}$ \\
\hline 1,2-Dichloropropane & Water & 1 & $\mu \mathrm{g} / \mathrm{L}$ \\
\hline 2-Butanone & Water & 5 & $\mu \mathrm{g} / \mathrm{L}$ \\
\hline 1,1,2-Trichloroethane & Water & 1 & $\mu \mathrm{g} / \mathrm{L}$ \\
\hline Trichloroethene & Water & 1 & $\mu \mathrm{g} / \mathrm{L}$ \\
\hline 1,1,2,2-Tetrachloroethane & Water & 1 & $\mu \mathrm{g} / \mathrm{L}$ \\
\hline Methyl Methacrylate & Water & 1 & $\mu \mathrm{g} / \mathrm{L}$ \\
\hline 1,2,3-Trichlorobenzene & Water & 1 & $\mu \mathrm{g} / \mathrm{L}$ \\
\hline Xylene (o) & Water & 1 & $\mu \mathrm{g} / \mathrm{L}$ \\
\hline 2-Chlorotoluene & Water & 1 & $\mu \mathrm{g} / \mathrm{L}$ \\
\hline 1,2-Dichlorobenzene & Water & 1 & $\mu \mathrm{g} / \mathrm{L}$ \\
\hline 1,2,4-Trimethylbenzene & Water & 1 & $\mu \mathrm{g} / \mathrm{L}$ \\
\hline 1,2-Dibromo-3-Chloropropane & Water & 1 & $\mu \mathrm{g} / \mathrm{L}$ \\
\hline 1,2,3-Trichloropropane & Water & 1 & $\mu \mathrm{g} / \mathrm{L}$ \\
\hline Ethyl Methacrylate & Water & 1 & $\mu \mathrm{g} / \mathrm{L}$ \\
\hline tert-Butylbenzene & Water & 1 & $\mu \mathrm{g} / \mathrm{L}$ \\
\hline Isopropylbenzene & Water & 1 & $\mu \mathrm{g} / \mathrm{L}$ \\
\hline 4-Isopropyltoluene & Water & 1 & $\mu \mathrm{g} / \mathrm{L}$ \\
\hline \multicolumn{4}{|c|}{ Semivolatile organic compounds } \\
\hline 4-Nitroaniline & Water & 26 & $\mu \mathrm{g} / \mathrm{L}$ \\
\hline 4-Nitrophenol & Water & 26 & $\mu \mathrm{g} / \mathrm{L}$ \\
\hline Benzyl Alcohol & Water & 10 & $\mu \mathrm{g} / \mathrm{L}$ \\
\hline Benzaldehyde & Water & 10 & $\mu \mathrm{g} / \mathrm{L}$ \\
\hline 4-Bromophenyl-phenylether & Water & 10 & $\mu \mathrm{g} / \mathrm{L}$ \\
\hline Azobenzene & Water & 10 & $\mu \mathrm{g} / \mathrm{L}$ \\
\hline Caprolactam & Water & 10 & $\mu g / L$ \\
\hline 2,4-Dimethylphenol & Water & 10 & $\mu \mathrm{g} / \mathrm{L}$ \\
\hline 4-Methylphenol & Water & 10 & $\mu \mathrm{g} / \mathrm{L}$ \\
\hline 4-Chloroaniline & Water & 10 & $\mu \mathrm{g} / \mathrm{L}$ \\
\hline 2,2'-oxybis(1-Chloropropane) & Water & 10 & $\mu \mathrm{g} / \mathrm{L}$ \\
\hline Phenol & Water & 10 & $\mu \mathrm{g} / \mathrm{L}$ \\
\hline Pyridine & Water & 10 & $\mu \mathrm{g} / \mathrm{L}$ \\
\hline bis(2-Chloroethyl)Ether & Water & 10 & $\mu \mathrm{g} / \mathrm{L}$ \\
\hline bis(2-Chloroethoxy)methane & Water & 10 & $\mu \mathrm{g} / \mathrm{L}$ \\
\hline bis(2-Ethylhexyl)phthalate & Water & 10 & $\mu \mathrm{g} / \mathrm{L}$ \\
\hline Di-n-octylphthalate & Water & 10 & $\mu \mathrm{g} / \mathrm{L}$ \\
\hline Hexachlorobenzene & Water & 10 & $\mu \mathrm{g} / \mathrm{L}$ \\
\hline Anthracene & Water & 10 & $\mu \mathrm{g} / \mathrm{L}$ \\
\hline 2,4-Dichlorophenol & Water & 10 & $\mu \mathrm{g} / \mathrm{L}$ \\
\hline 2,4-Dinitrotoluene & Water & 10 & $\mu \mathrm{g} / \mathrm{L}$ \\
\hline Pyrene & Water & 10 & $\mu \mathrm{g} / \mathrm{L}$ \\
\hline Dimethylphthalate & Water & 10 & $\mu \mathrm{g} / \mathrm{L}$ \\
\hline Dibenzofuran & Water & 10 & $\mu \mathrm{g} / \mathrm{L}$ \\
\hline Atrazine & Water & 10 & $\mu \mathrm{g} / \mathrm{L}$ \\
\hline
\end{tabular}


Appendix 3. Constituents analyzed and reporting limits for analysis of water, streambed sediment, and fish tissue at the Ethan Allen Firing Range in northern Vermont.-Continued

[Constituent reporting levels for analysis of water (surface and ground) and solids (streambed sediment and fish tissue) collected at Ethan Allen Firing Range. All constituents were analyzed in surface- and ground-water samples. Major ions and trace elements were analyzed in streambed sediment and fish-tissue samples. Units are in mg/L, milligrams per liter; NTU, nephelometric turbitiy units; $\mu \mathrm{g} / \mathrm{L}$, micrograms per liter; $\mathrm{mg} / \mathrm{kg}$, milligrams per kilogram]

\begin{tabular}{|c|c|c|c|}
\hline Constituent & Media & Reporting limit & Units \\
\hline \multicolumn{4}{|c|}{ Semivolatile organic compounds--Continued } \\
\hline Benzo(g,h,i)perylene & Water & 10 & $\mu \mathrm{g} / \mathrm{L}$ \\
\hline Indeno(1,2,3-cd)pyrene & Water & 10 & $\mu \mathrm{g} / \mathrm{L}$ \\
\hline Benzo(b)fluoranthene & Water & 10 & $\mu \mathrm{g} / \mathrm{L}$ \\
\hline Fluoranthene & Water & 10 & $\mu \mathrm{g} / \mathrm{L}$ \\
\hline Benzo(k)fluoranthene & Water & 10 & $\mu \mathrm{g} / \mathrm{L}$ \\
\hline Acenaphthylene & Water & 10 & $\mu \mathrm{g} / \mathrm{L}$ \\
\hline Chrysene & Water & 10 & $\mu \mathrm{g} / \mathrm{L}$ \\
\hline Benzo(a)pyrene & Water & 10 & $\mu \mathrm{g} / \mathrm{L}$ \\
\hline 2,4-Dinitrophenol & Water & 25 & $\mu \mathrm{g} / \mathrm{L}$ \\
\hline 4,6-Dinitro-2-methylphenol & Water & 26 & $\mu \mathrm{g} / \mathrm{L}$ \\
\hline Dibenz(a,h)anthracene & Water & 10 & $\mu \mathrm{g} / \mathrm{L}$ \\
\hline Benzo(a)anthracene & Water & 10 & $\mu \mathrm{g} / \mathrm{L}$ \\
\hline 4-Chloro-3-methylphenol & Water & 10 & $\mu \mathrm{g} / \mathrm{L}$ \\
\hline 2,6-Dinitrotoluene & Water & 10 & $\mu \mathrm{g} / \mathrm{L}$ \\
\hline N-Nitroso-di-n-propylamine & Water & 10 & $\mu \mathrm{g} / \mathrm{L}$ \\
\hline Aniline & Water & 26 & $\mu \mathrm{g} / \mathrm{L}$ \\
\hline N-Nitrosodimethylamine & Water & 10 & $\mu \mathrm{g} / \mathrm{L}$ \\
\hline Benzoic Acid & Water & 26 & $\mu \mathrm{g} / \mathrm{L}$ \\
\hline Hexachloroethane & Water & 10 & $\mu \mathrm{g} / \mathrm{L}$ \\
\hline 4-Chlorophenyl-phenylether & Water & 10 & $\mu \mathrm{g} / \mathrm{L}$ \\
\hline Hexachlorocyclopentadiene & Water & 10 & $\mu \mathrm{g} / \mathrm{L}$ \\
\hline Isophorone & Water & 10 & $\mu \mathrm{g} / \mathrm{L}$ \\
\hline Acenaphthene & Water & 10 & $\mu \mathrm{g} / \mathrm{L}$ \\
\hline Diethylphthalate & Water & 10 & $\mu \mathrm{g} / \mathrm{L}$ \\
\hline Di-n-butylphthalate & Water & 10 & $\mu \mathrm{g} / \mathrm{L}$ \\
\hline Phenanthrene & Water & 10 & $\mu \mathrm{g} / \mathrm{L}$ \\
\hline Butylbenzylphthalate & Water & 10 & $\mu \mathrm{g} / \mathrm{L}$ \\
\hline $\mathrm{N}$-nitrosodiphenylamine & Water & 10 & $\mu \mathrm{g} / \mathrm{L}$ \\
\hline Fluorene & Water & 10 & $\mu \mathrm{g} / \mathrm{L}$ \\
\hline Carbazole & Water & 10 & $\mu \mathrm{g} / \mathrm{L}$ \\
\hline Hexachlorobutadiene & Water & 10 & $\mu \mathrm{g} / \mathrm{L}$ \\
\hline Pentachlorophenol & Water & 26 & $\mu \mathrm{g} / \mathrm{L}$ \\
\hline 2,4,6-Trichlorophenol & Water & 10 & $\mu \mathrm{g} / \mathrm{L}$ \\
\hline 2-Nitroaniline & Water & 26 & $\mu \mathrm{g} / \mathrm{L}$ \\
\hline 2-Nitrophenol & Water & 10 & $\mu \mathrm{g} / \mathrm{L}$ \\
\hline Naphthalene & Water & 10 & $\mu \mathrm{g} / \mathrm{L}$ \\
\hline 2-Methylnaphthalene & Water & 10 & $\mu \mathrm{g} / \mathrm{L}$ \\
\hline 2-Chloronaphthalene & Water & 10 & $\mu \mathrm{g} / \mathrm{L}$ \\
\hline 3,3'-Dichlorobenzidine & Water & 10 & $\mu \mathrm{g} / \mathrm{L}$ \\
\hline 1,1'-Biphenyl & Water & 10 & $\mu \mathrm{g} / \mathrm{L}$ \\
\hline Benzidine & Water & 26 & $\mu \mathrm{g} / \mathrm{L}$ \\
\hline 2-Methylphenol & Water & 10 & $\mu \mathrm{g} / \mathrm{L}$ \\
\hline 2-Chlorophenol & Water & 10 & $\mu \mathrm{g} / \mathrm{L}$ \\
\hline 2,4,5-Trichlorophenol & Water & 25 & $\mu \mathrm{g} / \mathrm{L}$ \\
\hline Acetophenone & Water & 10 & $\mu \mathrm{g} / \mathrm{L}$ \\
\hline Nitrobenzene & Water & 10 & $\mu \mathrm{g} / \mathrm{L}$ \\
\hline 3-Nitroaniline & Water & 26 & $\mu \mathrm{g} / \mathrm{L}$ \\
\hline
\end{tabular}




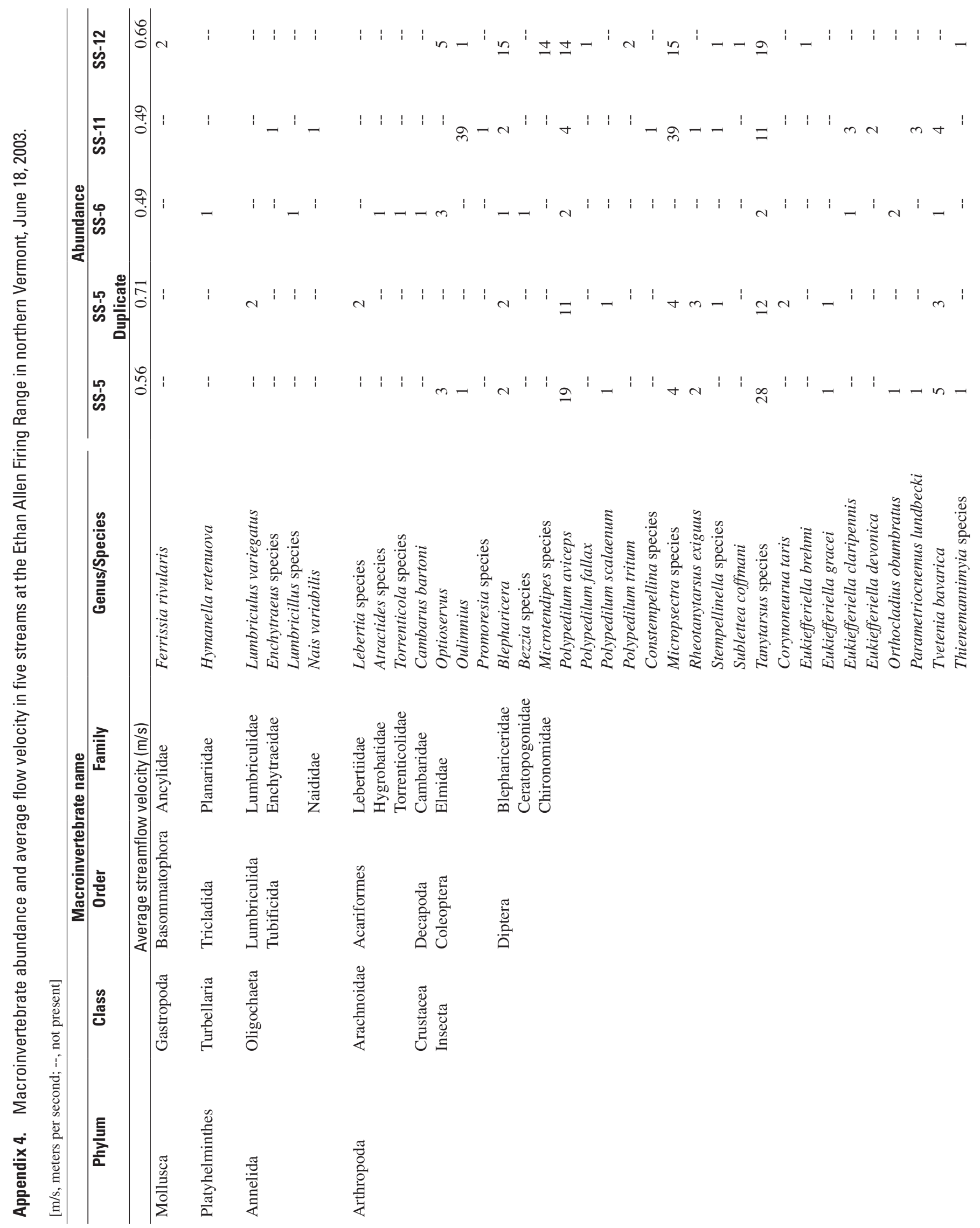


Appendixes 1-4 47

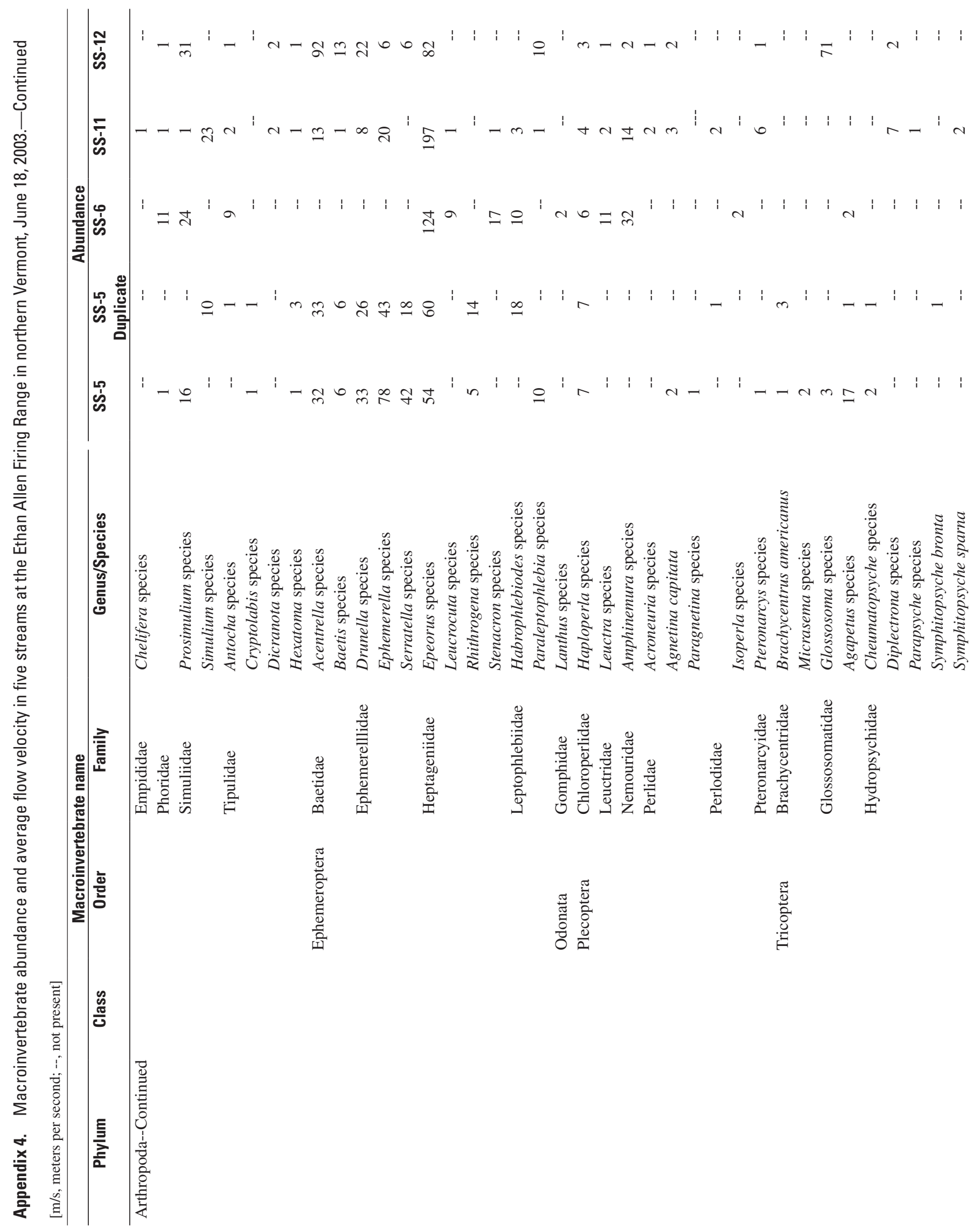




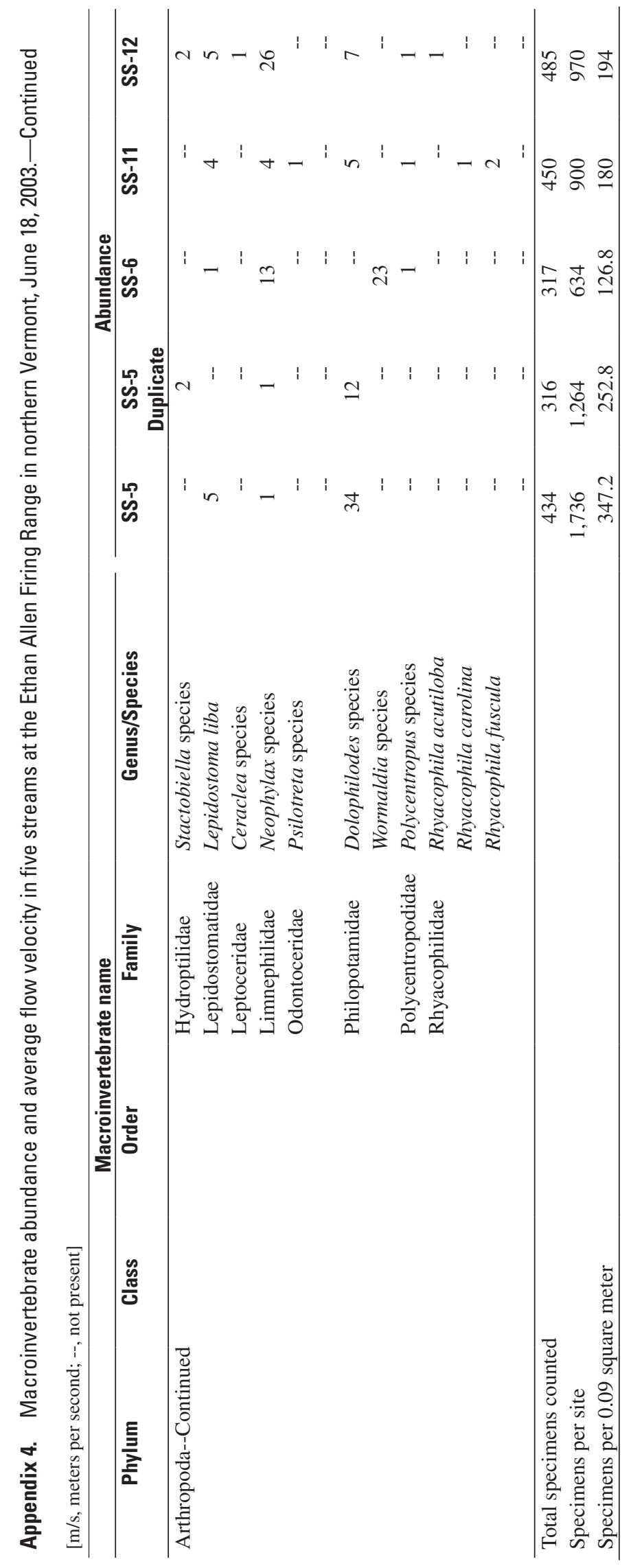


Prepared by the New Hampshire-Vermont Water Science Center Publications Unit

For more information concerning the research in this report, contact:

Brian Mrazik, Director

U.S. Geological Survey

NH-VT Water Science Center

361 Commerce Way

Pembroke, NH 03275

dc_nh@usgs.gov

or visit our Web site at:

http://nh.water.usgs.gov 